\title{
O potencial heurístico dos três problemas clássicos da matemática grega
}

\section{Suemilton Nunes Gervázio}

\section{DisSERTAÇÃO APRESENTADA}

$\mathrm{AO}$

Instituto DE MATEMÁtica E Estatística

DA

Universidade de SÃo Paulo

PARA

OBTENÇÃO DO TÍTULO

DE

Mestre em CiênCiAS

Programa: Pós - Graduação em Matemática

Orientador: Prof. Dr. Oscar João Abdounur

Durante o desenvolvimento deste trabalho o autor recebeu auxílio financeiro do $\mathrm{CNPq}$

São Paulo, Dezembro de 2015 


\section{O potencial heurístico dos três problemas clássicos da matemática grega}

Esta versão da dissertação contém as correções e alterações sugeridas pela Comissão Julgadora durante a defesa da versão original do trabalho, realizada em 15/12/2015. Uma cópia da versão original está disponível no Instituto de Matemática e Estatística da Universidade de São Paulo.

Comissão Julgadora:

- Prof. Dr. Oscar João Abdounur (Orientador) - IME - USP

- Prof ${ }^{\mathrm{a}}$. Abigail Fregni Lins - UEPB

- Prof. Dr. Adriana Cesar de Mattos - UFTM 


\section{AGRADECIMENTOS}

- A Deus, por ter me dado forças, coragem, fé, confiança, discernimento e por ter colocado em meu caminho pessoas essenciais para o meu fortalecimento, encorajando-me a seguir em busca dos meus objetivos.

- Aos meus pais, Maria José Gervázio e José Nunes Gervázio, por terem me concedido a vida, terem sempre me dado forças, mesmo quando tudo parecia está perdido e, apesar da distância, fizeram-se presentes por meio de orações.

- Ao meu orientador Oscar João Abdounur, por ter me ajudado durante todo o curso, motivando minha formação profissional, contribuindo exponencialmente com meus conhecimentos e além de disso, grande amigo. Sem dúvidas foi fundamental para a conclusão deste trabalho.

- Aos meus irmãos, pelo carinho e apoio durante momentos difícieis e alegres. Em especial a Valéria Gervázio e Simoni Gervázio.

- Aos meus familiares em geral, por ter me proporcionado momentos de lazer e descontração.

- A minha namorada, Valéria Santos, por estar ao meu lado durante quase todo o curso, me poporcionando momentos inesquecíveis. 
"Quem caminha com fé, persistência, determinação e autoconfiança, não há outro resultado a não ser o sucesso."

Suemilton Gervázio 


\section{DEDICATÓRIA}

A Deus, é sua toda honra e glória. Só tenho a lhe agradecer por tudo. 


\section{RESUMO}

GERVÁZIO, S. N. O potencial heurístico dos três problemas clássicos da matemática grega. 2015. 94 f. Dissertação (Mestrado) - Instituto de Matemática e Estatística, Universidade de São Paulo, São Paulo, 2015.

Este trabalho consiste em uma pesquisa acerca da análise do potencial heurístico resultado da não solução dos três problemas clássicos da matemática grega, via regra do uso exclusivo do compasso e da régua não graduada. Para uma melhor compreensão deste potencial, apresentaremos o histórico de tais problemas, fazendo posteriormente uma síntese geral sobre as principais concepções de filósofos e matemáticos sobre Heurística. Em seguida, demonstraremos algumas soluções alternativas para estes problemas, identificando nelas processos heurísticos. Finalmente introduziremos tais processos na resolução de problemas matemáticos, acompanhadas de possíveis implicações pedagógicas para o ensino dessa ciência.

Palavras - Chave: problemas clássicos da matemática grega, relação entre matemática e heurística, resolução de problemas matemáticos. 


\section{ABSTRACT}

\section{GERVÁZIO, S. N. The heuristic potential of the three classical problems}

of Greek mathematics. 2015. 94 f. Dissertação (Mestrado) - Instituto de Matemática e Estatística, Universidade de São Paulo, São Paulo, 2015.

This work consists of research about the potential of heuristic analysis result of no solution of the three classical problems of Greek mathematics, via rule of exclusive use of the compass and no graduated scale. For a better understanding of this potential, it presents the history of such problems, then making a general overview about the main ideas of philosophers and mathematicians on Heuristics. Then we demonstrate some alternative solutions to these problems, identifying them heuristic processes. Finally we introduce such processes in mathematical problem solving, accompanied by possible pedagogical implications for the teaching of science.

Keywords: classical problems of Greek mathematics, relationship between mathematics and heuristics, mathematical problem solving. 


\section{SUMÁRIO}

Introdução 2

1 Histórico dos três problemas clássicos da matemática grega 5

$\begin{array}{lll}1.1 & \text { As anetodas e relatos acerca do surgimento dos três problemas clássicos } & 7\end{array}$

$1.2 \quad$ A restrição dos problemas a régua não graduada e compasso $\ldots . . .11$

2 As concepções de filósofos e/ou matemáticos acerca da abordagem

\begin{tabular}{ll}
\hline heurística para o desenvolvimento do conhecimento & 17
\end{tabular}

$2.1 \quad$ O Método de Arquimedes e a origem da heurística . . . . . . . . . . 19

2.2 A Coleção Matemática de Pappus: o papel heurístico da análise . . . 20

2.3 Regras para a Direção do Espírito de Descartes e A arte de Resolver Problemas de George Polya: o desenvolvimento da heurística . . . . . 22

$2.4 \quad$ A heurística na Lógica do Desenvolvimento Matemático: Provas e Refutações de Lakatos e a Formação do Espírito Científico de Bachelard 24

2.5 Heurística: A Ciência do Pensamento Criador de Puchkin e a Intuição Heurística de Bazarian. . . . . . . . . . . . . . . . . . . . 27

3 Identificando a Heurística como a ciência da procura e invenção:

\begin{tabular}{|l|lllllll|}
\hline soluções & alternativas & para & os & três & problemas & clássicos & da \\
\hline matemática grega
\end{tabular}


3.1 .5 A solução de Nicomedes - a conchóide. . . . . . . . . . . . . . 42

$3.1 .6 \quad$ A solução de Diocles - a cissóide . . . . . . . . . . . . . . . . 44

3.2 Soluções alternativas para a quadratura do círculo . . . . . . . . . . 46

$3.2 .1 \quad$ A solução de Hípias . . . . . . . . . . . . . . . . . . . . 46

$3.2 .2 \quad$ A solução de Arquimedes. . . . . . . . . . . . . . . . . . 48

3.3 Soluções alternativas para a trissecção de um ângulo qualquer $\ldots . .51$

3.3.1 A redução do problema da trissecção a construção por nêusis . 52

3.3 .2 A solução de Nicomedes . . . . . . . . . . . . . . . . 55

3.3 .3 A soluçã̃o de Hípias . . . . . . . . . . . . . . . . . . . 56

3.3 .4 As soluções atribuídas a Arquimedes $\ldots \ldots \ldots \ldots$. . . . 58

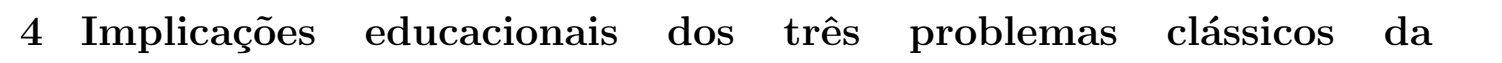
matemática grega para o ensino 61

4.1 Dinamizando a resolução do problema da duplicação do cubo por meio de dobraduras . . . . . . . . . . . . . . . . . . . . 63

4.2 Utilizando a espiral de Arquimedes para resolver o problema da trissecção do ângulo - uma aplicação pedagógica . . . . . . . . . . . . 74

\begin{tabular}{ll}
\hline Conclusão & 79
\end{tabular}

\begin{tabular}{ll}
\hline Referências Bibliográficas & 82
\end{tabular} 


\section{INTRODUÇÃO}

A matemática teve seu desenvolvimento dado, em certa medida, pela procura de resolver problemas, alguns deles relacionados com adaptação e sobrevivência. $\mathrm{Na}$ busca por essas resoluções, o Homem, de um ponto de vista individual ou social, necessitava de um conhecimento cada vez mais sofisticado. Estes problemas matemáticos desafiavam a inteligência dos estudiosos, que eram movidos pela busca de conhecimento, para tentar entender as peculiaridades e o esplendor da matemática.

Neste aspecto, sabemos que a Grécia antiga foi a principal civilização a impulsionar o progresso da matemática no mundo antigo, onde as principais ferramentas de resolução de problemas eram as famosas construções geométricas, cujo princípio fundamental era representar qualquer grandeza por meio de um segmento de reta. Essas construções foram indispensáveis para o desenvolvimento de toda a geometria que conhecemos hoje, pois, exigiam alto nível de conhecimento sobre propriedades das figuras geométricas.

Mesmo tendo sido os gregos pioneiros nessas construções e apesar de terem habilidades matemáticas destacáveis, alguns destes tipos de problemas tornaramse especiais, pois, conseguiram resistir a todas as tentativas de resolução. Tais problemas ficaram conhecidos como os três problemas clássicos da matemática grega, a saber, a duplicação do cubo, a trissecção do ângulo e a quadratura do círculo.

A busca da resolução destes três problemas de construção teve início no período helênico, que foi do século VI a.C. ao século V d.C. Os referidos problemas foram desafiadores para os matemáticos da época, pois, se sobressaíram irresolúveis a todos que tentaram os resolver, utilizando apenas a régua não graduada e o compasso. Com base em [8] esse impasse durou mais de dois mil anos, o que veio a ocasionar 
inúmeros estudos na área de Matemática e promover o seu desenvolvimento.

A dificuldade de resolver tais problemas encantou várias gerações de matemáticos e amadores até o século XIX, talvez também pelo fato dos enunciados serem extremamente simples. Isto estimulou a capacidade inventiva dos estudiosos da matemática, conformando em grande medida as atividades de pesquisa matemática dos gregos. Neste sentido, podemos dizer que a matemática grega teve contribuição para seu progresso, em certo aspecto, dada pela busca de resolver os três problemas clássicos, assim como a matemática atual evolui a partir de respostas a problemas desafiadores.

O estudo da geometria foi influenciado diretamente pela busca da solução destes problemas, o que veio a proporcionar valiosas descobertas matemáticas, como as cônicas, as curvas cúbicas, quadráticas e transcendentes. Assim, se destaca o quão importante foi a geometria para o desenvolvimento da matemática e os referidos problemas clássicos encontra-se neste contexto como alguns de seus norteadores deste progresso, visto que foi por intermédio da procura das soluções desses simples problemas de construções que surgiram várias descobertas da geometria, como veremos no desenvolver deste trabalho.

Pode-se dizer que a beleza desses problemas encontrava-se na sua não resolução utilizando apenas a régua não graduada e o compasso, já que esses instrumentos eram bastante simples e resolviam diversos problemas de construção. No entanto, este aparente empecilho foi crucial para a procura de soluções com base em outras ferramentas. Neste sentido, os gregos foram bastante proativos, pois ao não encontrar solução apenas com os instrumentos euclidianos (régua não graduada e compasso), criaram soluções engenhosas.

Após mais de 2000 anos do surgimento de tais problemas na Grécia antiga, o matemático francês Pierre Laurent Wantzel (1814 - 1848) apresentou no ano de 1837, uma demonstração para a impossibilidade de resolução dos problemas da duplicação do cubo e da trissecção do ângulo, com o uso apenas da régua não graduada e o compasso. Logo em seguida, Carl Louis Ferdinand von Lindemann (1852 - 1939) em 1882 demonstrou a impossibilidade da construção da quadratura do círculo, usando apenas os mesmos instrumentos citados anteriormente, essa demonstração foi graças a sua prova da transcendência do número $\pi$ sobre o corpo dos números racionais. Podemos afirmar que essas provas da impossibilidade de construção dos três problemas surgiram do desenvolvimento da aritmética, álgebra e análise.

Com isso, durante os meus estudos da graduação e do mestrado, ao deparar frequentemente com estes três famosos problemas da matemática grega, é que me 
surgiu o interesse em pesquisar mais detalhadamente qual é o potencial heurístico destes problemas para o desenvolvimento da matemática. Visto que a atividade heurística, que pode ser considerada como a arte da procura e da descoberta, é, até certo ponto, uma ferramenta indissociável do processo de aprendizagem e progresso do conhecimento científico.

Assim, para entendermos melhor o potencial heurístico destes três problemas, organizamos o presente trabalho em quatro capítulos. No primeiro faremos uma exposição histórica abrangente acerca dos três problemas, mostrando anetodas de seus surgimentos e possíveis porquês da "restrição" à régua não graduada e compasso.

No segundo capítulo, será exposta a importância da heurística para o desenvolvimento do conhecimento científico, fazendo uma síntese sobre as origens das atividades heurísticas em O Método de Arquimedes, a heurística nas obras Coleção Matemática de Pappus, Regras para a Direção do Espírito de Descartes e A arte de Resolver Problemas de George Polya e por fim, consideraremos os vestígios heurísticos em A Formação do Espírito Científico de Bachelard, A Lógica do Desenvolvimento Matemático: provas e refutações de Lakatos, Heurística: A Ciência do Pensamento Criador de Puchkin e Intuição Heurística de Bazarian. Esta explanação sobre heurística e conhecimento científico será importante para a compreensão do progresso matemático, movido muito possivelmente, pelas implicações das atividades heurísticas envolvidas na procura de solução dos três problemas em questão.

No Terceiro capítulo, mostraremos soluções dos três problemas clássicos da matemática grega que concernem ao fim do presente trabalho, realizadas por importantes estudiosos matemáticos, como Arquimedes, Platão, Eratóstenes, Menécmo e Diócles. Serão expostas também as engenhosas construções feitas por estes matemáticos para encontrar soluções que denominaremos alternativas 1 como é o caso da máquina de Platão, A Quadratriz (ou trissectriz) de Hípias, entre outras. Além disso, serão expostas as heurísticas por trás da descoberta dessas soluções e os benefícios matemáticos trazidos pela falta de solução dos problemas, fazendo o uso apenas da régua não graduada e do compasso.

Por fim, no quarto e último capitulo, faremos uma exposição acerca das possíveis implicações educacionais para o ensino da matemática, tendo como subsídios atividades heurísticas, que colocadas em destaque ao serem relacionadas com os três problemas clássicos da matemática, apresentam potencial pedagógico matemático.

\footnotetext{
${ }^{1}$ Soluções por meio de construções geométricas com instrumentos diferentes de régua e compasso.
} 


\section{CAPÍTULO 1}

\section{HISTÓRICO DOS TRÊS PROBLEMAS CLÁSSICOS DA MATEMÁTICA GREGA}

A matemática que foi desenvolvida na Grécia era essencialmente geométrica, quase tudo era feito com base na geometria, por exemplo, o conceito de um número era a sua associação ao comprimento de um segmento de reta. Neste contexto, construir um número significava construir um segmento de reta e o comprimento desse segmento era o número desejado. Para d'Acampora (2014, pg. 11) "Os gregos foram responsáveis pelo acelerado desenvolvimento da Matemática no mundo antigo tendo as construções geométricas como principal método de resolver problemas através da ideia de representar uma grandeza qualquer na forma de um segmento de reta."

Nas operações de soma, subtração, multiplicação e divisão de dois números, os gregos faziam o uso de construções geométricas por meio de retas e circunferências. Essas atividades ficaram conhecidas como as construções com régua e compasso e a partir da unidade (segmento unitário) era possível construir os números naturais e os números fracionários.

Com base em [11] e [18] podemos dizer que na medida em que o livro Os Elementos de Euclides se difundia, os gregos foram se interessando cada vez mais pelos problemas geométricos, em especial os problemas que envolviam construções. Três desses problemas tiveram uma notável repercussão por terem conseguido resistir 
a todas as tentativas de resolução. Esses problemas ficaram conhecidos como os três problemas clássicos da matemática grega e são a quadratura do circulo, a duplicação do cubo e a trissecção do ângulo. Eles consistem em:

O problema da duplicação do cubo: seja um cubo qualquer de aresta a, determinar, usando apenas régua não graduada e compasso, a aresta b de outro cubo, onde o seu volume seja o dobro do volume do primeiro cubo, isto é, construir a aresta de um cubo cujo volume e dobro do volume de um cubo dado.
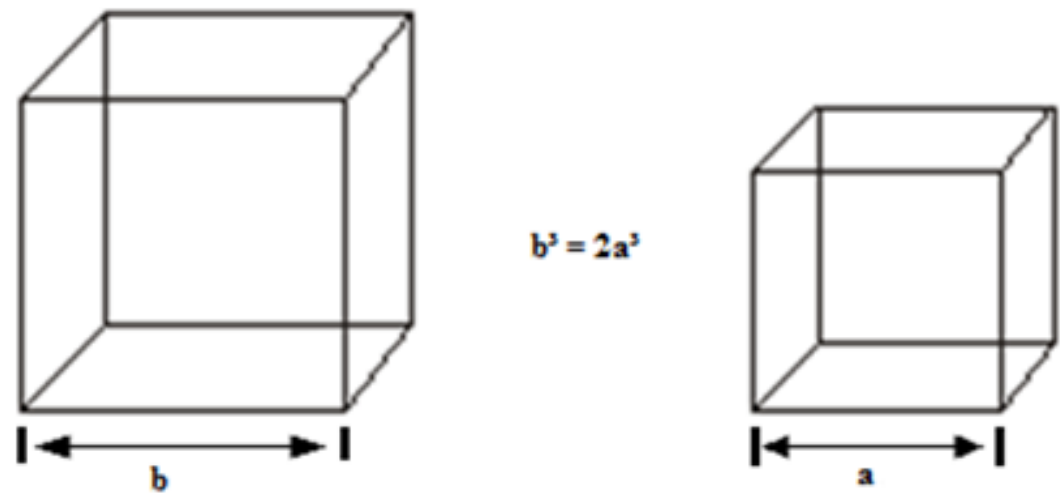

O problema da quadratura do círculo: seja um círculo qualquer, construir, usando apenas régua não graduada e compasso, um quadrado, cuja área seja igual à área desse círculo.

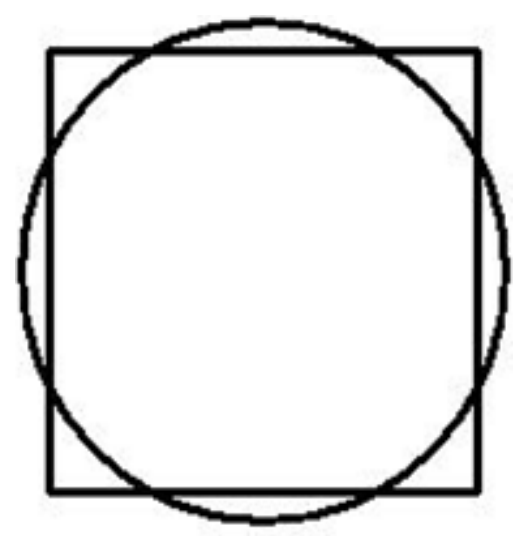

O problema da trissecção do ângulo: seja um ângulo qualquer, construir, usando apenas régua não graduada e compasso, um ângulo igual a terça parte do ângulo dado, ou seja, dividir um ângulo qualquer em três partes iguais. 


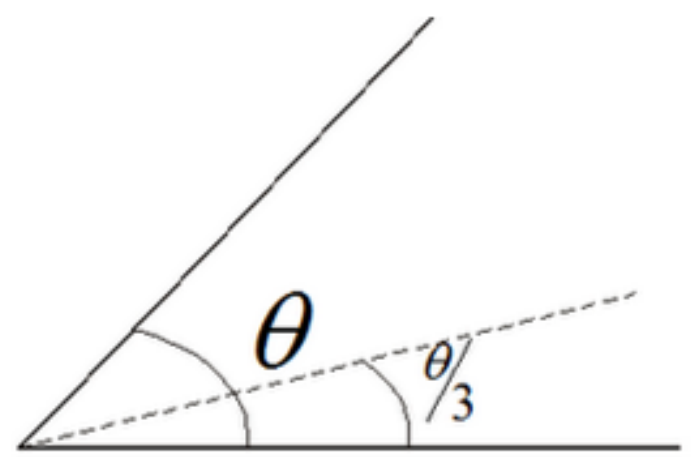

Pode-se dizer que o desenvolvimento da geometria na Grécia foi dado, em grande medida, pelas investigações realizadas na busca de tentar solucionar estes três problemas. De fato, eles foram resolvidos com grande engenhosidade, o que requeria alto nível de compreensão das construções geométricas. No entanto, as soluções encontradas necessitavam de outras curvas especiais, que não era a reta nem o círculo, infringindo a regra inicial dos problemas. Na concepção de [34,

A parte mais substancial do percurso efetuado pela matemática grega estava subordinada à geometria, cujo desenvolvimento parece ter sido influenciado pelas investigações feitas para tentar resolver estes três problemas clássicos da geometria grega. O raciocínio matemático dos gregos baseava-se, quase unicamente, nas formas e figuras geométricas. Um segmento de reta representava também o seu próprio comprimento; o produto de dois segmentos de reta representava uma área retangular; o produto de três segmentos de reta representava um volume paralelepipédico. (SOUSA, 2001, pg. 8)

A compreensão destes três problemas será fundamental para o desenvolvimento desta dissertação, já que mostraremos o potencial heurístico da procura de resolvêlos. Assim, compreender minuciosamente o enunciado do problema é crucial no que concernem os objetivos deste trabalho.

\subsection{As anetodas e relatos acerca do surgimento dos três problemas clássicos}

Uma questão que naturalmente se faz ao estudar os três problemas clássicos da matemática grega é: como eles surgiram? Existem várias lendas sobre a origem destes problemas, algumas delas inclusive contraditórias.

Começamos então, a relatar sobre o problema da duplicação do cubo. Este certamente é o que tem mais anetodas envolvidas no seu surgimento. Para tanto, recorremos a Eratóstenes de Cirene, que foi um bibliotecário no século III a.c. 
da famosa biblioteca de Alexandria. Para [4] ele era muito estimado por seus contemporâneos, sendo considerado um homem a frente do seu tempo, pois, tinha conhecimentos sobre diversos ramos das ciências da época. No livro The Ancient Tradition of Geometric Problems, (Knorr, 1993, pg. 17), consultar [20], Wilbur Knorr afirma possuir relatos que informam os primeiros estudos sobre a duplicação do cubo, advindos de duas fontes diferentes, que eram possivelmente de Eratóstenes de Cirene. Uma dessas fontes era um fragmento do seu diálogo Platonicus, que tinha sido preservado por Plutarco e Teão de Esmirna, cujas inscrições eram do século II a.C. e a outra fonte era uma escritura em formato de uma carta que Eratóstenes escreveu para o rei do Egito Ptolomeu III Evergeta.

No entanto, conforme [24] os principais conhecimentos históricos que temos sobre o problema da duplicação do cubo se devem a Eutócio de Àscalon, que foi um comentador do início do século VI d.C. Ele reproduziu a carta de Eratóstenes ao rei Ptolomeu, na qual havia duas lendas distintas acerca do surgimento do referido problema.

Segundo [39], nessa reprodução de Eutócio consta o seguinte diálogo:

Eratóstenes a Ptolomeu, saúde! Conta-se que um dos antigos poetas trágicos fez aparecer Mino em cena, no ato de mandar construir um túmulo a Glauco; e que Mino, verificando que este tinha de cada lado cem pés de comprimento, disse: pequeno espaço na verdade concedeste ao sepulcro de um rei; duplica-o, conservando-lhe sempre a forma cúbica, ficarão imediatamente duplicados todos os lados do sepulcro. Ora, é claro que ele se enganava. De fato duplicando-se os lados duma figura plana, esta fica quadruplicada, e uma figura sólida ficará octuplicada. Então foi agitada entre geômetras a questão de saber como se podia duplicar uma dada figura sólida qualquer, conservando-lhe a forma. E este problema foi chamado duplicação do cubo. Todos ficaram duvidosos, durante muito tempo, até que Hipócrates de Chios achou que, se entre duas linhas retas, das quais a maior seja dupla da menor, se inscreverem duas médias em proporção contínua, o cubo ficará duplicado; transmudando-se, assim, uma dificuldade noutra não menor. Narra-se também que, mais tarde, os Délios, levados pelo oráculo a dobrar um certo altar, caíram no mesmo embaraço. E alguns embaixadores vieram procurar os geômetras que conviviam com Platão na Academia, para os excitar a descobrir o que lhes era exigido. Estes ocuparam-se do assunto com diligência, e diz-se que, tendo procurado inserir duas meias entre duas retas, Arquitas Tarentino o resolveu com o semi-cilindro, e Eudóxo mediante certas linhas curvas. A estes geômetras seguiram-se outros, que conseguiram tomar mais perfeitas as demonstrações, mas não a construção e a sua exequibilidade prática, exceptuando talvez Menecmo, e com grande trabalho. (VASCONCELOS, 1925, pg. 365)

Van der Waerden (1903 - 1996) deu mais detalhes sobre a segunda lenda, na concepção dele, Teão de Esmirna cita que: 
Na sua obra intitulada Platonicus, Eratóstenes relata que quando o deus anunciou aos habitantes de Delos, através dum oráculo, que se queriam ver-se livres de uma praga deveriam construir um altar duplo daquele que existia, os artífices ficaram muito embaraçados por não serem capazes de descobrir como um sólido podia ser duplicado mantendo a sua forma. Foram perguntar a Platão como o haviam de fazer, tendo este respondido que o significado das palavras do oráculo não era que o deus queria duplicar o altar, mas que o seu desejo, ao dar-lhes esta tarefa, era envergonhar os gregos pela sua indiferença pela matemática e pela sua ignorância no que diz respeito à geometria. (Van der WAERDEN, 1954, pg. 161)

Em síntese, segundo [5] a primeira lenda diz que o rei Minos mandou fazer um túmulo para o seu filho Glauco. Ao saber que o túmulo tinha sido construído em formato de um cubo e que a aresta media 100 pés, ele disse que a construção tinha sido feita demasiadamente pequena e ordenou imediatamente que o túmulo fosse duplicado, no entanto, que não se perdesse seu belo formato original. Já a segunda lenda afirma que em 427 a.C um quarto da população de Atenas teria sido dizimada por uma peste, incluindo Péricles que foi um grande estadista da Grécia antiga. Um grupo, preocupado com a praga que se espalhava, foi enviado ao oráculo de Apolo, o Deus do Sol, na cidade de Delos (por esse motivo, o problema da duplicação do cubo também é conhecido como o problema deliano), para perguntar como a peste poderia ser combatida. O oráculo então os informou que deveriam duplicar o volume do cubo que sustentava a estátua do Deus Apolo. Os arquitetos ficaram perplexos por não saberem como construir um cubo, cujo volume fosse duas vezes maior que outro.

Não se sabe ao certo até que ponto essas duas lendas estão corretas, mas a de levar em consideração que de fato este problema teve seu início e desenvolvimento na Grécia antiga. Neste sentido [34] explana que "A tradição deste problema não é muito clara, mas, verdadeiras ou falsas as lendas e suposições sobre o seu aparecimento, um fato é certo: este problema foi estudado na Academia de Platão, pois foram atribuídas soluções, que não se enquadram na geometria do primeiro livro de Euclides, a vários geômetras da época, como, por exemplo, Arquitas e Menecmo". (SOUSA, 2001, pg. 49)

Em relação às origens do problema da quadratura do círculo, podemos dizer que não se conhece claramente alguma anetoda que envolva o seu surgimento. No entanto, para alguns historiadores este problema é o mais famoso entre os três problemas matemáticos aqui em questão e, na percepção de d'Acampora (2014, pg. 13), "O problema da quadratura do círculo é muito natural e também é com certeza o mais antigo." 
Para [5] um dos motivos do surgimento desse problema pode ter sido ao fato de que os gregos em seus problemas de construções geométricas, trabalhavam com quadraturas de regiões planas. Neste contexto quadrar uma região plana significa traçar um quadrado que tenha área igual à área da região dada, usando apenas régua não graduada e compasso. Assim, como o problema de quadrar qualquer região poligonal foi completamente resolvido nos Elementos de Euclides, então era de se esperar que em seguida se fosse tentar quadrar regiões limitadas por linhas curvas, e uma escolha bem natural seria quadrar o círculo.

Segundo [31] a primeira referência ao problema da quadratura do circulo foi encontrada no Papiro de Rhind ou Ahmes, cerca de 1600 a.C. Aristóteles indagava que este problema surgiu na verdade da procura da média geométrica, ou seja, meia proporcional, mas que se tinha perdido esse detalhe e restava-se apenas o problema em si. Já na acepção de [35], esse problema tinha advindo do problema da quadratura do retângulo, como indaga Carvalho (2008, pg. 04) "Para Szabo, o problema de quadratura que deu origem a todos os outros foi o de fazer a quadratura do retângulo. Este problema é facilmente resolvido com régua e compasso usando o resultado que em um triângulo retângulo a altura relativa à hipotenusa é a meia proporcional entre os segmentos que ela determina sobre a hipotenusa."

O terceiro problema, a trissecção de um ângulo, difere dos outros anteriores em alguns pontos. Primeiro porque é possível trissectar ângulos com amplitudes especiais usando apenas régua não graduada e o compasso, como é caso do ângulo de $90^{\circ}$. Pappus faz essa construção em seu livro IV da Coleção Matemática. Já a quadratura do circulo e duplicação do cubo não são impossíveis de serem realizadas, por mais especiais que sejam a aresta do cubo ou ao raio do círculo. Outra divergência interessante é que não se conhece nenhuma lenda que remete ao problema da trissecção do ângulo.

Este problema pode então ter surgido da necessidade dos gregos de construir polígonos regulares como aponta Sousa (2001, pg. 13) "Não é conhecida a origem do problema da trissecção do ângulo, mas é muito provável que tenha surgido no segmento da construção de polígonos regulares. Por exemplo, para construir um polígono regular de nove lados é necessário trissectar um ângulo de $120^{\circ}$ ".

Alguns pesquisadores apontam outras idéias para o surgimento de tal problema, Júnior (2013, pg. 12), por exemplo, acredita que "Este é o mais antigo dos três problemas. É possível que tenha surgido da necessidade dos egípcios em medir ângulos entre estrelas para determinar o tempo da noite". Já [34] ainda acrescenta que o problema pode ter surgido como consequência da bissecção de um ângulo, 
construção que tinha sido demonstrada nos Elementos de Euclides. "No entanto, não será de excluir a hipótese de este problema ter nascido como uma extensão natural da bissecção de um ângulo (Elementos I, 9), tarefa extremamente fácil e possível de executar com régua não graduada e compasso. A divisão de um segmento de reta em várias partes iguais, com os instrumentos euclidianos, é simples e poderá, também, ter levado ao problema da trissecção do ângulo, num esforço de transpor para ângulos o que era possível efetuar em segmentos de reta." (SOUSA, 2001, pg. 14)

De fato, há vários relatos acerca do aparecimento dos três problemas clássicos da matemática grega. Como as fontes que mostram os prováveis motivos do surgimento são bastante antigas e que não são primárias, então não dá para se provar que realmente foram os argumentos expostos anteriormente os motivos para tais surgimentos. No entanto, um fato indiscutível é que estes problemas surgiram e se disseminaram na antiga Grécia e que teve grande notoriedade entre os estudiosos da matemática.

\subsection{A restrição dos problemas a régua não graduada e compasso}

Primeiro começaremos a definir o que são construções geométricas utilizando régua não graduada e compasso, para tanto, consideraremos comprimentos como não negativos. Para construir segmentos de reta de um determinado tamanho necessitaremos de um dado segmento de reta de comprimento unitário e a partir desse segmento realizando um número finito de operações com um compasso - que devem ter pernas tão compridas quanto necessárias e que quando o levantamos do papel suas pernas se fecham, ou seja, não transferem medidas, mas que podem ser usado para traçar uma circunferência com centro em um ponto dado e que passa por outro ponto qualquer, previamente determinado - e uma régua sem marcas, ou seja, não pode ser utilizada para medir, mas pode ser usada para construir um segmento de reta tão grande quanto se deseja, contendo dois pontos dados. Assim conseguiremos construir o segmento desejado.

Realizando uma sequência finita de passos, a partir das instruções dadas anteriormente, obteremos pontos, por meio de operações de intersecção entre retas, entre circunferências ou entre retas e circunferências. Desse modo, com os pontos obtidos por essas intersecções, podemos traçar novas retas e novas circunferências, e assim por diante, num processo finito. Se forem dados inicialmente alguns pontos 
podemos construir a partir destes outros pontos e, sucessivamente, novas retas e circunferências.

Vejamos algumas construções geométricas utilizando régua não graduada e compasso, com base em [15].

Um triângulo equilátero de aresta igual a um segmento de reta dado

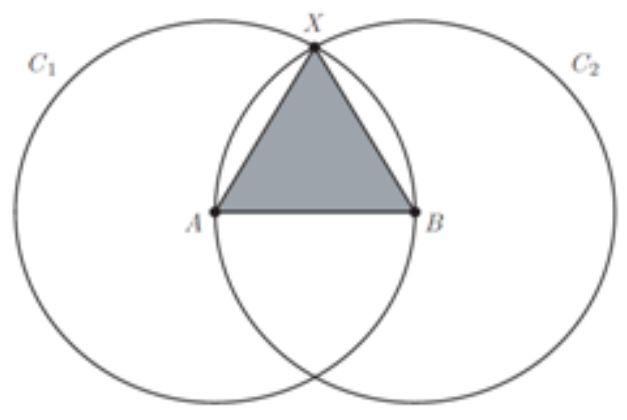

A partir do segmento de reta $\overline{A B}$ como mostra à figura acima, para construir um triângulo equilátero com aresta de comprimento igual ao segmento $\overline{A B}$, procedemos da seguinte maneira: se constrói uma circunferência, $C 1$, de centro no ponto $A$ e raio $\overline{A B}$. Em seguida, se constrói outra circunferência, $C 2$, de centro no ponto $B$ e raio $\overline{B A}$. Assim os dois pontos de intersecção das circunferências $C 1$ e $C 2$ formarão dois triângulos equiláteros de aresta $\overline{A B}$, um desses está em destaque na figura anterior, o triangulo $A B X$. De fato, como o lado $\overline{A X}$ é raio da circunferência $C 1$, então por construção $\overline{A B}=\overline{A X}$. Como o lado $\overline{B X}$ é raio da circunferência $C 2$, então por construção $\overline{B X}=\overline{B A}=\overline{A B}$. Logo o triangulo $A B X$ é equilátero.

Uma reta, paralela a outra reta dada $r$ e que passa por um dado ponto $P$ exterior a $r$

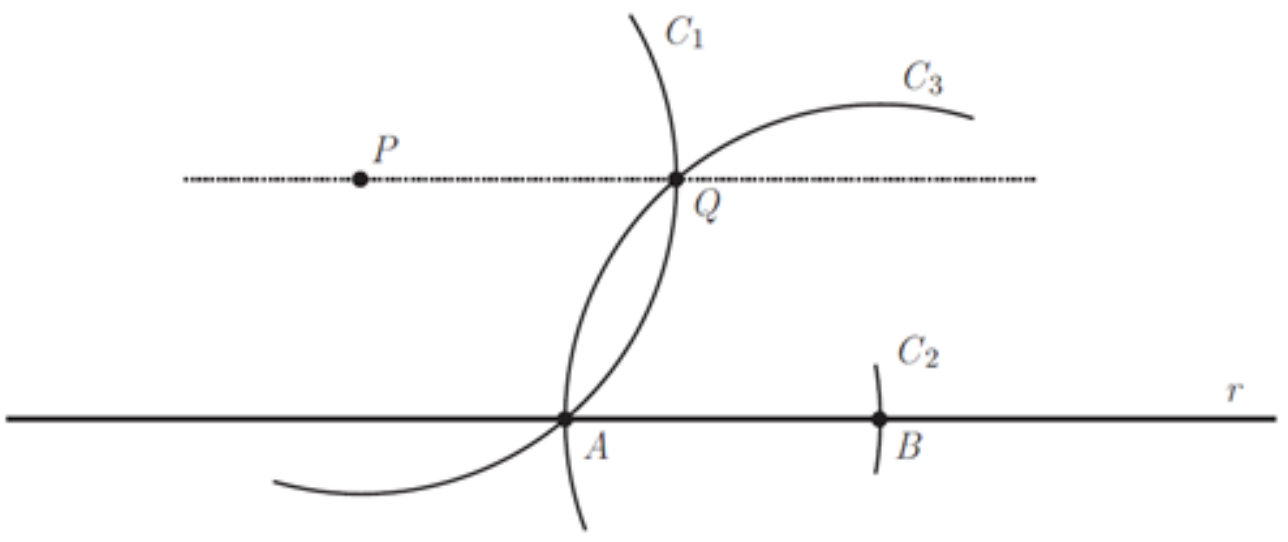


Conforme figura acima, seja a reta $r$ e o ponto $P$, para construir uma reta paralela a $r$ e que passa por $P$, procedemos da seguinte maneira: devemos construir três circunferências de mesmo raio, cujo comprimento deve ser maior que a distância do ponto $P$ a reta $r$. A primeira circunferência, $C$ 1, com centro no ponto $P$, que interceptara a reta $r$ em dois pontos, marcaremos apenas o ponto da direita, $A$. A partir desse ponto traçaremos a segunda circunferência, $C 2$, com centro no ponto $A$, que interceptara a reta $r$ também em dois pontos, novamente marcaremos apenas o ponto da direita, $B$. A partir desse ponto traçaremos a terceira circunferência, $C 3$, com centro no ponto $B$, que interceptara a circunferência $C 1$ em dois pontos, $Q$ e $A$. Assim, os pontos $P$ e $Q$ formam a reta que é paralela a reta $r$. De fato, por construção as três circunferências $C 1, C 2$ e $C 3$ possuem o mesmo raio, $\operatorname{logo} \overline{P A}=$ $\overline{A B}=\overline{B Q}=\overline{Q P}$ e os pontos $P, A, B$ e $Q$ são vértices de um losango. Com isso, a reta $r$ e a reta formada pelos pontos $P$ e $Q$ serão paralelas.

\section{A bissetriz de um ângulo dado}

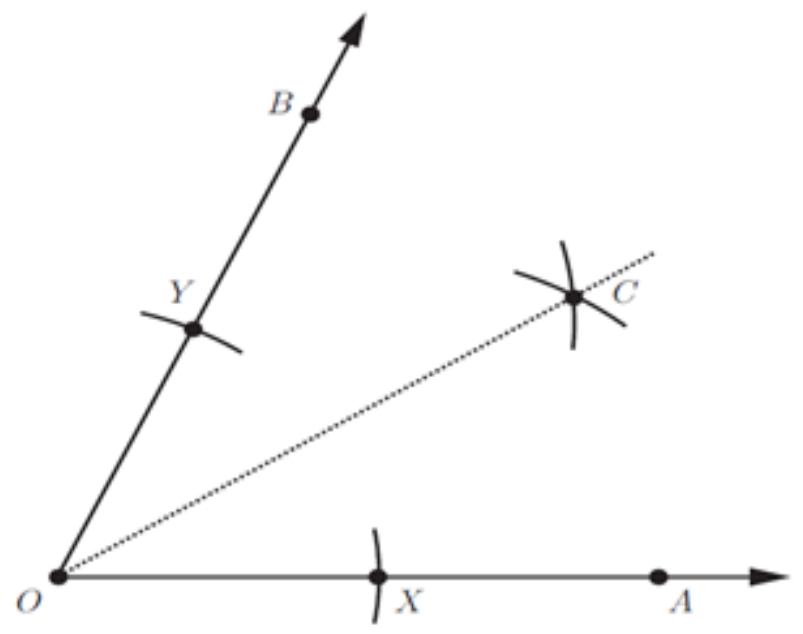

Conforme figura a cima, seja um ângulo $A \hat{O} B$, para construir uma reta que bissecta o ângulo, ou seja, divide-o em duas partes iguais procedemos da seguinte maneira: trace um círculo de centro em $O$, que interceptara os pontos $X$ e $Y$ nos lados do ângulo $A \hat{O} B$. Depois traça-se dois círculos com o mesmo raio de centro nos pontos $X$ e $Y$, de tal modo que estes dois círculos se interceptem em pelo menos um ponto, $C$. Assim a semi-reta $\overrightarrow{O C}$ é a bissetriz do ângulo $A \hat{O} B$. De fato, por construção, $\overline{O Y}$ $=\overline{O X}$ e $\overline{Y C}=\overline{X C}$. Assim, os pontos $O, Y, C$ e $X$ são vértices de um quadrilátero, logo a semi-reta $\overrightarrow{O C}$ divide o ângulo $A \hat{O} B$ em dois ângulos iguais, pois a semi-reta $\overrightarrow{O C}$ é a diagonal do quadrilátero $O Y C X$.

As construções geométricas com estes instrumentos tiveram seu apogeu com o aparecimento dos Elementos de Euclides por volta de 300 a.C. Movido, muito 
provavelmente, pelo fato de que todas as construções nos postulados desse livro foram realizadas apenas com o uso da régua não graduada e do compasso, que por essa razão, são conhecidos também como instrumentos euclidianos.

No entanto, é sabido que pelo menos dois dos três problemas clássicos já eram conhecidos antes de Euclides, conforme aponta Roque (2012, pg. 155) "Entre os diversos problemas matemáticos clássicos difundidos antes de Euclides estão o da duplicação do cubo e o da quadratura do círculo. O famoso problema da trissecção do ângulo será tratado por nós mais adiante, uma vez que deve ter se tornado um problema mais tardiamente que os outros no contexto de reflexões sobre técnicas de construção."

Assim, se esses problemas já existiam antes de Euclides, o que teria então motivado o aparecimento da regra, o uso exclusivo de régua não graduada e compasso, nas construções geométricas? Talvez seja pelo fato de que as construções com essas ferramentas eram consideradas mais elementares e sempre que tais construções fossem possíveis, métodos mais avançados deveriam ser evitados. No entanto, é indubitável que os gregos utilizavam outros instrumentos capazes de construir soluções sofisticadas para os problemas de construção, como afirma [40]

A idéia por vezes expressa de que os gregos permitiam somente construções com régua e compasso é inadmissível. Ela é negada pelas numerosas construções que nos chegaram para a duplicação do cubo e a trissecção do ângulo. No entanto, é verdade de que tais construções eram consideradas mais elementares, e Pappus afirma que sempre que uma construção for possível com régua e compasso métodos mais avançados não deveriam ser usados. (van der Waerden, pg. 263)

Para [19], os problemas de construções, eram assuntos de grande interesse na Grécia antiga e que os passos utilizados para a solução dos problemas eram considerados como um jogo. Assim a restrição a régua e compasso pode ser vista como uma regra deste jogo. Como podemos inferir a partir do trecho: "Os matemáticos da Grécia Antiga já tinham um grande interesse por estas construções e segundo [6], o traçado de construções era conhecido como um jogo, que tinha suas regras, e era considerado como um dos jogos mais fascinantes e absorventes daquela época." (JÚNIOR, 2013, pg. 6)

Outra possibilidade para tal restrição poderia ser a filosofia platônica, que valorizava muito a matemática teórica. Podendo, por este motivo, não usar os movimentos mecânicos em seus problemas de construções geométricas. [31] é bem radical neste sentido ao afirma que Platão desprezava construções mecânicas. Segundo sua percepção: 
(...) Como já dito, para explicar o motivo dessa restrição é comum apelar para a filosofia platônica. Por valorizar a matemática teórica, Platão teria desprezo pelas construções mecânicas, realizadas com ferramentas de verdade. A régua e o compasso apesar de serem instrumentos de construção, podem ser representados, respectivamente pela reta e pelo círculo, figuras geométricas com alto grau de perfeição. (ROQUE, 2012, pg. 160)

Barbosa (et al, NETO, 2010, pg. 2) também aponta para Platão a restrição a régua e compasso. Segundo ele: "Matemáticos gregos, Platão em particular, entendiam a reta e o círculo como sendo as curvas perfeitas e, por isso, deveriam ser suficientes para realizar quaisquer construções. Surge, então, a chamada restrição a reta e ao círculo, ou, em linguagem mais utilizada pelos matemáticos e historiadores da matemática, a restrição à régua e ao compasso."

Temos ainda que [5], além de concordar com as idéias de [31] e de [2], indaga que outra possível explicação para tal fato seria aos problemas causados pela descoberta da irracionalidade de $\sqrt{2}$. Para ele:

Além da idéia de perfeição ideal atribuída ao círculo e à linha reta, uma outra razão possível para a restrição à régua e ao compasso pode ter sido a crise devida à descoberta da irracionalidade de $\sqrt{2}$, número que pode no entanto ser construído com régua e compasso. Esses instrumentos eram a garantia da existência de números como este. (CARVALHO, 2008, pg. 2)

Em relação a restrição a régua não graduada e compasso, presente nos Elementos de Euclides, que foi o impulsionador dos problemas de construções geométricas, com o uso apenas desses instrumentos, Roque (2012, pg. 160 - 163) aponta duas possíveis explicações: A primeira seria o cunho pedagógico do livro, ou seja, as construções realizadas com estes instrumentos seriam mais simples de compreender, pois, não exigiriam uma teoria adicional. Isso implica que a restrição não seria necessariamente uma proibição, mas sim uma otimização. Já a segunda seria a necessidade de ordenação e sistematização da geometria, visando uma melhor organização da matemática.

De fato, os motivos pelos quais impuseram a restrição do uso apenas da régua não graduada e compasso, nos problemas de construções geométricas na Grécia antiga, em nada interferirão nos propósitos deste trabalho, pois, mostraremos as possíveis implicações para o desenvolvimento da matemática devido a existência dessa regra. Por isso, as causas dessa imposição não serão aqui abordadas, mas é fato que era algo bastante forte na geometria grega, já que inúmeros estudiosos da matemática tentaram resolver os três problemas aqui em questão fazendo o uso de tais instrumentos, por mais de 2 mil anos. Como não conseguiam tais soluções, 
então abriram mão desta regra e, a partir daí, evoluções significantes tornaram-se possíveis no âmbito da matemática, em especial, na geometria, como veremos nos capítulos seguintes. 


\section{CAPÍTULO 2}

\section{AS CONCEPÇÕES DE FILÓSOFOS E/OU MATEMÁTICOS ACERCA DA ABORDAGEM HEURÍSTICA PARA O DESENVOLVIMENTO DO CONHECIMENTO}

Pode-se dizer, em grande medida, que para promover o desenvolvimento de qualquer área de conhecimento, torna-se necessário instigar o intelecto de pessoas nestas áreas. A mente criativa comporta-se, frente a problemas desafiadores, buscar novos caminhos, novas percepções e conceitos para encontrar a solução dos problemas. Tais buscas, ao não ter sucesso com os mecanismos rotineiros, se dão por novas vias.

Diante disso, promover a inquietação mental dos indivíduos, no sentido de motivá-los a criar novos mecanismos que encaminham a soluções de problemas, em particular de problemas matemáticos, pode ser primordial para impulsionar a descoberta de novas técnicas de solução, novos paradigmas científicos e até mesmo a novas linhas de pesquisa na área. Para tanto, adquirir conhecimento sobre as táticas e os caminhos que levam a solução de problemas, pode ser mais importante do que a resolução do problema em si.

Assim, observa-se que para alcançar o êxito na solução de problemas é preciso 
cultivar uma mente que seja fértil à procura e descoberta, algo que pode proporcionar a inteligência criativa, que na acepção de Sternberg (2000, pg. 163) “... é a capacidade de ir além do estabelecido para gerar idéias novas e interessantes".

Nesse sentido, a criatividade é o que desenvolve a ciência, visto que a descoberta promove novas ramificações científicas, que são desencadeadoras de conhecimentos inéditos. Nessa mesma linha de raciocínio, [37] aponta que "Criatividade é um processo que torna alguém sensível aos problemas, deficiências, hiatos ou lacunas nos conhecimentos, e o leva a identificar dificuldades, procurar soluções, fazer especulações ou formular hipóteses, testar e retestar essas hipóteses, possivelmente modificando-as e a comunicar os resultados." (TORRANCE, 1976, pg. 22).

Todo esse discurso acerca da arte da procura de novos caminhos, nos é indispensável para apresentar a noção de heurística. A essa forma diferenciada de pensar, desenvolver e encontrar o conhecimento, que foi algo bastante significante para o desenvolvimento da ciência na Grécia antiga, como veremos no decorrer deste trabalho, associa-se uma Heurística, cujo termo provém da Grécia antiga e significa encontrar, descobrir, inventar, etc. Para o dicionário português, o seu significado é: No contexto científico "a ciência que tem por objetivo a descoberta dos fatos"; no contexto de problematização "a arte de inventar, de fazer descobertas" e no contexto pedagógico "método educacional que consiste em fazer descobrir pelo aluno o que se lhe quer ensinar". De modo geral, podemos dizer, segundo [23], que é "um conjunto de regras e métodos que conduzem à descoberta, à invenção e à resolução de problemas", ou seja, a heurística está relacionada com os processos relativos à descoberta e a invenção, processos estes fundamentais para a compreensão da natureza da ciência.

É interessante ressaltar aqui que a atividade heurística está sendo amplamente estudada na atualidade em quatro áreas distintas, com até certo grau de aproximação, mas bastante diferenciados. São elas: A heurística na psicologia cognitiva, voltada para pesquisa de inteligência artificial, onde este termo é usado como sendo um conjunto de estratégias adquiridas por um ser cognitivo, o qual a partir de objetos e valores, pré-determinados, pode se chegar a novas descobertas. A heurística na pesquisa matemática, onde é voltada para a procura de procedimentos que levam a resolução de problemas, isto é, como o ser humano raciocina para encontrar tais soluções. A heurística na pesquisa histórica, que se relaciona com métodos e procedimentos que garantem certo grau de certeza nas pesquisas. E por último a heurística na pesquisa filosófica, onde se estuda a invenção de novas proposições e os processos de elaboração do pensamento. Mais detalhes sobre essas 
linhas de pesquisa em heurística, consultar [17].

No que concerne a essa dissertação, para uma melhor compreensão sobre a importância das atividades heurísticas e o desenvolvimento matemático, exibiremos uma síntese com as principais idéias de alguns matemáticos e filósofos sobre tal importância. Esta compreensão sobre a heurística será fundamental, pois norteará os dois últimos capítulos sobre o potencial heurístico trazidos pela busca da solução dos três problemas clássicos da matemática grega.

\subsection{O Método de Arquimedes e a origem da heurística}

Arquimedes (287 - 212 a.C.) nasceu e viveu a maior parte de sua vida na cidade de Siracusa, na costa da Sicília, atual Itália. Escreveu varias obras que englobam mecânica, aritmética, astronomia e óptica, para o propósito desse trabalho vamos nos remeter especificamente ao seu livro O Método.

Este livro é sem dúvida a mais antiga obra de que se tem conhecimento, que mostra os meios pelos quais se chegou a resolução dos problemas através de estratégias inovadoras, isto é, que envolvem procedimentos heurísticos. Nesta obra, Arquimedes implantou um modelo totalmente inovador na matemática grega, como afirma [13]:

(...) Além disso, convém salientar um aspecto inovador na matemática produzida por Arquimedes que se caracteriza por um rompimento com a tradição grega geométrica encaminhada a determinar medidas (áreas e volumes) e analogias entre essas medidas (quadratura, cubaturas e retificações de curvas) estabelecida pelos geômetras do século III a.C. e, em particular, por Euclides de Alexandria; assim, a geometria arquimediana procurou considerar e demonstrar proposições sobre áreas e volumes limitadas por novas linhas ou superfícies curvas (quadratura da parábola e espirais, cubaturas da esfera, cilindro, conóides e esferóides), equilíbrio de planos e seus centros de gravidade, sobre corpos flutuantes. (FILHO, 2004, pg. 54)

Arquimedes para resolver os problemas geométricos recorreu a métodos mecânicos, algo totalmente inovador para a época. Esse fato tornou sua obra muito importante, pois, mostravam seus métodos heurísticos para resolver problemas geométricos. Ainda segundo [13]:

Para estabelecer seus resultados, Arquimedes utilizava-se de procedimentos heurísticos, isto é, recursos provenientes das investigações mecânicas, pois suas descobertas geométricas estão fundadas e relacionadas com postulados e proposições 
de estática e hidrostática, formuladas nos tratados Sobre o equilíbrio dos planos e Sobre os corpos flutuantes, que não só permitem elaborar um esboço prévio das soluções ou demonstrações de alguns problemas ou teoremas geométricos, mas sugerem um delineamento plausível que possibilitará facultar essas soluções ou demonstrações por meio de um raciocínio, rigorosamente lógico, firmado em verdades desde logo aceitas sem demonstração e em outras verdades de antemão demonstradas em conformidade com os padrões clássicos da geometria grega, através do método de exaustão. (FILHO, 2004, pg. 54)

O Método foi a única obra onde Arquimedes revela seus procedimentos e métodos utilizados para se chegar aos resultados. Neste livro, Arquimedes tinha, muito provavelmente, o interesse de mostrar para outros estudiosos de matemática as motivações que o fez utilizar a mecânica para encontrar soluções de problemas geométricos e como ele chegou a tais soluções, como podemos ver no trecho abaixo: "Arquimedes para Eratóstenes, saudações. Enviei a você em uma ocasião anterior alguns dos teoremas que descobri, apresentando simplesmente os enunciados e convidando-o a descobrir as demonstrações, as quais não forneci naquela época. (...) Escrevi as demonstrações destes teoremas neste livro e agora o envio a você. (...)" (ASSIS, 2008, pg. 15)

Assim, podemos observar claramente que Arquimedes fez o uso de procedimentos heurísticos na sua obra O Método. Esse fato pode ser observado em dois aspectos: o primeiro reside no seu interesse em explicar o que levou a encontrar novas estratégias para solucionar problemas matemáticos e como ele chegou a tais soluções. O segundo seria a sua engenhosidade de usar métodos mecânicos para resolver tais problemas, algo totalmente novo na cultura grega.

\subsection{A Coleção Matemática de Pappus: o papel heurístico da análise}

Pappus de Alexandria (290 - 350) foi um dos últimos importantes matemáticos do período helênico. Ele organizou uma obra composta por oito livros, que ficou conhecida como A Coleção Matemática de Pappus. Esta obra é um resumo de conhecimentos antigos de alguns matemáticos gregos precedentes e foram acrescentadas também novas proposições e importantes comentários, além de inúmeros esclarecimentos, algumas correções e críticas, o que vem a caracterizar a obra como sendo de cunho heurístico.

Como aponta Filho (2004, pg. 4) "Quanto A Coleção Matemática (...), em que Pappus aborda e conceitua os aspectos referentes à análise e síntese, que fornecem 
subsídios à atividade heurística." Ele indaga também que muito provavelmente Pappus organizou esta obra como uma espécie de resumo, objetivando uma melhor compreensão do estudo dos tratados de matemáticos anteriores.

Para [41], A Coleção Matemática de Pappus é uma importante obra para a matemática, onde ele fez fantásticas contribuições, esclarecendo demonstrações difíceis, explicando-as de forma diferenciada e sempre que possível fazendo analogias a casos mais simples de compreender. Como se segue:

Pappus não se limita, com efeito, a expor notáveis proposições devidas a seus antecessores acompanhando-as de uma grande quantidade de lemas destinados a esclarecer as passagens difíceis das suas demonstrações, mas ele estabelece freqüentemente demonstrações diferentes; ele as estende a casos particulares ou análogos, aplica-as à solução de problemas novos ou já resolvidos anteriormente de uma outra maneira, e completa numerosas proposições inteiramente novas extraídas de seu próprio cabedal, as quais indicam pesquisas já muito avançadas no que chamamos agora a geometria superior. (Ver EECKE, 1982, pg. 13)

Para Pappus, na matemática dos geômetras gregos antigos, existiam a análise e a síntese. A análise corresponde ao método que se usa para descobrir a resolução ou demonstração de teoremas ou problemas geométricos. É nesse fato que se encontram características de atividades heurísticas. Conforme Filho (2004, pg. 69) "Fica explícito que os antigos geômetras utilizavam um procedimento heurístico para solucionar seus problemas matemáticos, isto é, um modelo matemático que utiliza a análise para encontrar a solução de um problema ou a demonstração de um teorema e, em seguida, a síntese para expor o que se encontrou para solucionar o problema ou a demonstração de um teorema (...)"

Assim, podemos dizer que a abordagem heurística na referida obra de Pappus esta relacionada com os processos de análise que estão ligados diretamente com elementos do raciocínio, mediados muito provavelmente pela intuição, o que vem a promover novos meios de procura e descobertas e, consequentemente a resolução de problemas matemáticos. Segundo [28], “(..) Dessa forma, a análise é considerada como um método que possui características heurísticas, pois envolve um processo lógico, que antecede uma demonstração rigorosa, e que é finalizada pela síntese e que tem como objetivo determinar soluções para os problemas geométricos e matemáticos." (PLURES. 2009, pg. 25) 


\subsection{Regras para a Direção do Espírito de Descartes e A arte de Resolver Problemas de George Polya: o desenvolvimento da heurística}

René Descartes (1596 - 1650) dá continuidade aos trabalhos de Pappus, ao preservar em sua obra Regras para Direção do Espírito, as mesmas definições de síntese e análise. Esta última, como foi discutida anteriormente, refere-se à arte da procura, ou seja, a atividade heurística.

Para Descartes a análise se refere a elementos a priori, enquanto que a síntese se refere a elementos a posteriori. Segundo ele, um exemplo desses elementos a posteriori é o livro Os Elementos de Euclides, onde está presente apenas a síntese, isto é, apresenta somente um modelo axiomático. Para [7] essa falta da análise a priori, mostra que "Dessa forma, os antigos não quiseram revelar o método de análise, o qual ficou preservado na obra de Pappus." (Chaves. 2011, pg. 5)

Descartes em sua obra acima supracitada, defende uma heurística que relacione os elementos que envolvem o estudo de um objeto, promovendo conexões para se chegar ao verdadeiro conhecimento. Neste livro ele propôs um ambicioso conjunto de regras, as quais davam um método geral para a solução de qualquer problema. Em resumo, ele quis reduzir qualquer problema existente a um problema matemático.

Para tanto, Descartes dividia o processo de resolução de problemas em três etapas: primeiro reduzir todo problema algébrico a um problema contendo apenas equações. Depois reduzir todo problema matemático a um problema algébrico e por último, reduzir qualquer problema a um problema matemático.

Percebemos assim que esse propósito de reduzir todo tipo de problema a um problema matemático é um tanto utópico. No entanto, a sua abordagem heurística diante a resolução de problemas é bastante adequada e aplicável.

George Polya (1887 - 1985) nasceu na Hungria e é considerado um dos matemáticos mais importantes do século XX. Teve grande contribuição para a heurística no que concerne a resolução de problemas, na qual ele, assim com Pappus e Descartes, utilizou o modelo de síntese e análise, de modo que a análise seria a invenção, isto é, consiste em conceber um plano e a síntese seria a execução do plano.

Uma de suas obras mais importantes que se refere a esse assunto é A Arte de Resolver Problemas, publicada em 1957. Ele foi o primeiro matemático que apresentou uma heurística voltada especificamente para a resolução de problemas 
matemáticos. Conforme podemos observar, ele indaga que "A Heurística trata do comportamento humano em face de problemas." (POLYA, 1994, pg. 88)

Para Polya a matemática é uma ciência, onde a observação e a analogia são fundamentais, além disso, a matemática poderia ser vista como uma ciência rigorosa, como aquela apresentada nos elementos de Euclides, más, poderia ser também uma ciência experimental e indutiva. Ele considerava a heurística como sendo um ramo de estudo da lógica, da filosofia ou psicologia, onde se estuda o conjunto de métodos e regras que levam a descoberta e invenção. Como se observa em [29]:

Heurística, Heurética ou ars inveniendi era o nome de um certo ramo de estudo, não bem delimitado, pertencente à Lógica, à Filosofia ou à Psicologia, muitas vezes delineado mas raramente apresentado com detalhes, hoje praticamente esquecido. O objetivo da Heurística é o estudo dos métodos e das regras da descoberta e da invenção. Alguns indícios desse estudo podem ser encontrados em trabalho dos comentaristas de Euclides. A este respeito, Pappus tem uma passagem particularmente interessante. As mais famosas tentativas de sistematização da Heurística devem-se a Descartes e a Leibniz, ambos grandes matemáticos e filósofos. Bernard Bolzano apresentou notável descrição pormenorizada da Heurística. (POLYA, 1994, pg. 86)

Para uma melhor compreensão sobre a heurística na resolução de problemas, Polya reserva um capítulo dessa sua obra, para elaborar um tipo de dicionário de heurística. Conforme Filho (2004, pg. 139) "Para explicar e discutir o processo heurístico e os elementos que dele fazem parte, Polya elabora um Pequeno Dicionário de Heurística com sessenta e sete artigos, dando o significado e fundamentos de cada um deles."

Assim como Descartes, Polya considera que a analogia é algo bastante útil para a resolução de problemas, tanto que a primeira palavra que consta no seu "dicionário de heurística" é a palavra analogia. Como ele mesmo indaga:

A analogia permeia todo o nosso pensamento, a nossa fala cotidiana e as nossas conclusões triviais, assim como os modos de expressão artística e as mais elevadas conclusões científicas. Ela é empregada nos mais diferentes níveis. É comum o uso de analogias vagas, incompletas ou obscuras, porém a analogia pode alcançar-se ao nível do rigor matemático. Todos os tipos de analogia podem desempenhar uma função na descoberta da solução e, por isso, não devemos desprezar nenhum deles. (POLYA, 1994, pg. 29)

Polya aponta ainda que o "Raciocínio heurístico é aquele que não se considera final e rigoroso, mas apenas provisório e plausível, e que tem por objetivo descobrir a solução do problema que se apresenta. Somos muitas vezes levados a usar o 
raciocínio heurístico. Teremos a absoluta certeza quando chegarmos à solução completa, mas frequentemente, antes de chegarmos à certeza absoluta, teremos de nos satisfazer com uma estimativa mais ou menos plausível. É possível que precisemos do provisório antes de atingirmos o final. Para chegarmos a uma demonstração rigorosa, é necessário o raciocínio heurístico, assim como andaimes são necessários à construção de um edifício." (Polya, 1994, pg. 132)

Nesse sentido, ele considera também que o raciocínio heurístico tem como componente principal a indução. Sendo assim, o raciocínio indutivo, que segundo ele é o processo da descoberta de leis gerais pela observação de casos particulares, poderia ser considerado como um caso especial deste raciocínio heurístico.

Diante do aspecto heurístico existente entre a análise e a síntese nos processos de resolução de problemas, Polya concebe um plano de como resolver um problema, o qual contém quatro fases: A primeira fase trata-se da compreensão do problema, isto é, todo os dados devem estar compreendidos para que se prossiga com a resolução. A segunda fase consiste no estabelecimento de um plano, ou seja, se deve encontrar um planejamento de como proceder frente ao problema. Na terceira fase, o plano que foi estabelecido na fase anterior deve ser executado. Por fim, na quarta fase, os procedimentos utilizados para a execução do plano devem ser revistos, isto é, deve ser feito um retrospecto, analisando e discutindo a solução apresentada.

Finalizando, Polya deixa explícito a importância das atividades heurísticas para o processo de construção do conhecimento matemático. Ele indaga que Leibniz já dizia "Nada é mais importante do que observar as origens da invenção, as quais são, na minha opinião, mais interessantes que as próprias invenções." (POLYA, 1994, pg. 96). Assim, na sua acepção, procurar entender as origens e desenvolvimento das invenções é fundamental para a absorção do "verdadeiro" conhecimento cientifico.

\subsection{A heurística na Lógica do Desenvolvimento Matemático: Provas e Refutações de Lakatos e a Formação do Espírito Científico de Bachelard}

Imre Lakatos (1922 - 1974), nascido na Hungria foi um filosofo não só da matemática como também de outras ciências. Ele teve reconhecimento internacional devido a sua metodologia nos programas de investigação científica, descrevendo de 
que maneira pode ser dado o progresso do conhecimento científico.

Lakatos ultrapassa as idéias de Polya, pois, além de desenvolver uma heurística, que analisa a matemática além do seu rigor lógico, isto é, como uma ciência indutiva e experimental, ele orienta seu trabalho para a invenção e a descoberta, por intermédio de hipóteses ou até mesmo de adivinhações.

O seu livro A Lógica do Desenvolvimento Matemático: Provas e Refutações, que foi baseado em sua tese de doutorado, publicado em 1976, logo após a sua morte, é uma obra muito importante no que concernem os princípios da atividade heurística. Ele busca mostrar que ao contrario do que prega a matemática formalista, a matemática "não deve se desenvolver por meio de um aumento monótono de quantidade de teoremas deduzidos indubitavelmente, mas por meio da melhoria incessante de adivinhações, especulações e críticas, pela lógica das demonstrações e refutações."

Lakatos baseou-se nos trabalhos de Polya e de Karl Popper que foi um filósofo do século XX. Ele considerava que a filosofia das ciências e a história das ciências tinham uma relação indissociável, ou seja, "A filosofia da ciência sem a história da ciência é vazia; a história da ciência sem a filosofia da ciência é cega" (LAKATOS, 1983. pg. 107).

A filosofia da matemática que Lakatos defendia, se baseava em apresentar como acontece o desenvolvimento da matemática. Para ele, o progresso da matemática é dado pelo método das provas e refutações, como aponta Trevisan (2013, pg. 139) "Lakatos discute a construção do conhecimento matemático apresentando o método das provas e refutações como possibilidade e engrenagem motora do desenvolvimento matemático."

Para embasar essas suas concepções, Lakatos desenvolve no primeiro capítulo do livro citado acima, um diálogo fictício entre alunos de uma escola, os quais discutem arduamente a validade da fórmula de Euler. Conforme [38]:

(...), no primeiro capítulo do livro supracitado, na busca de tentar provar o teorema de Euler de que em um poliedro vale a relação $\mathrm{V}-\mathrm{A}+\mathrm{F}=2$, ele emprega seu método e utiliza-se de elementos como: inflar um poliedro até obter-se uma esfera, recortar com uma tesoura e encaixar, retirar uma face e expandir (planificar) sobre um quadro negro. O autor apresenta esse capítulo em forma de um diálogo entre uma turma de aula e seu professor, as notas de rodapé desse capítulo acabam por guiar o leitor sobre a própria história da demonstração dessa fórmula. Esses elementos são utilizados de maneira geral na busca da criação de lemas para a prova apresentada e na tentativa de melhorar a conjectura buscando enquadrar-se frente aos contra exemplos, ou seja, no processo de investigação. Essa aceitação da utilização desses procedimentos parece-nos muito propício para aplicação em ambientes educacionais, 
2. As concepções de filósofos e/ou matemáticos acerca da abordagem heurística para o desenvolvimento do conhecimento

pensando no desprendimento do rigor que o mesmo admite, já que muitas vezes um dos empecilhos para utilização das provas e demonstrações em sala de aula que tem sido apresentado, versa justamente sobre a necessidade de um alto grau de rigor, que muitas vezes os alunos ainda não adquiriram. (TREVISA, 2013, pg. 140 - 141)

Por fim, Lakatos faz uma crítica ao modelo euclidiano de como é desenvolvido e apresentado o conhecimento matemático, pois, na sua concepção, os livros que seguem este modelo omitem todo o caminho que tornou possível os resultados ali apresentados, o que torna a obra muito "carregada". Em suas palavras:

A metodologia euclidiana desenvolveu certo estilo obrigatório de apresentação. Vou designá-lo "estilo dedutivista". Este estilo começa com uma lista laboriosamente feita de axiomas, lemas e/ou definições. Os axiomas e definições frequentemente parecem artificiais e mistificadamente complicados. Nunca se fica sabendo como essas complicações surgiram. A lista de axiomas é seguida de teoremas cuidadosamente redigidos. Estes por sua vez estão carregados de pesadas condições; parece impossível que alguém jamais os tivesse suposto. (LAKATOS, 1978, pg. 185).

Outro importante filósofo das ciências que trata sobre o tema em questão é Gaston Bachelard (1884 - 1962), principalmente no que diz respeito a teoria do conhecimento, não usou especificamente o termo heurística em suas obras. No entanto, podemos detectar, principalmente no seu livro A Formação do Espírito Científico: Contribuições para uma Psicanálise do Conhecimento, varias passagens que remetem às atividades heurísticas.

Bachelard começa definindo o que são obstáculos epistemológicos, que na sua visão são barreiras que impedem a absorção do conhecimento científico. Como segue:

Quando se procuram as condições psicológicas do progresso da ciência, logo se chega à convicção de que é em termos de obstáculos que o problema do conhecimento científico deve ser colocado. E não se trata de considerar obstáculos externos, como a complexidade e a fugacidade dos fenômenos, nem de incriminar a fragilidade dos sentidos e do espírito humano: é no âmago do próprio ato de conhecer que aparecem, por uma espécie de imperativo funcional, lentidões e conflitos. É aí que mostraremos causas de estagnação e até de regressão, detectaremos causas de inércia às quais daremos o nome de obstáculos epistemológicos. (BACHELARD, 1996, pg. 13)

Mesmo não remetendo-se especificamente a matemática, nem aos processos heurísticos, fica evidente o seu apelo a construção do conhecimento por intermediação da procura e descoberta, o que vem a caracterizar heurística. Como podemos identificar em [1]: "Para o espírito científico, todo conhecimento é resposta a uma pergunta. Se não há pergunta, não pode haver conhecimento científico. Nada é evidente. Nada é gratuito. Tudo é construído." (BACHELARD, 1996, pg. 18) 
Bachelard é muito enfático ao afirmar que não se deve abordar o conhecimento científico apenas como algo pronto, acabado e perfeito, ao contrário, devemos levar em conta todo o processo de formulação e re-formulação das idéias que encaminharam a síntese de tais conhecimentos. Isto mostra a sua propensão a trabalhar com uma "ciência viva", que é capaz de promover uma evolução cientifica para a humanidade.

Para tanto, ele indaga que "Logo, toda cultura científica deve começar, como será longamente explicado, por uma catarse intelectual e afetiva. Resta, então, a tarefa mais difícil: colocar a cultura científica em estado de mobilização permanente, substituir o saber fechado e estático por um conhecimento aberto e dinâmico, dialetizar todas as variáveis experimentais, oferecer enfim à razão razões para evoluir." (BACHELARD, 1996, pg. 24) Percebemos assim a sua apologia a práticas educativas voltadas para a dinamicidade do ensino, isto é, a promoção de metodologias educacionais com bases em preceitos heurísticos.

Por fim, ele faz uma crítica ao ensino regular atual que deixa muito a desejar no que diz respeito à formação científica do aprendiz, pois, esse processo de ensino extrai todo o caráter histórico-epistemológico da ciência, que está intimamente relacionado com heurística. Conforme suas palavras "A ciência moderna, em seu ensino regular, afasta-se de toda referência à erudição. E dá pouco espaço à história das idéias científicas." (BACHELARD, 1996, pg. 34)

\subsection{Heurística: A Ciência do Pensamento Criador de Puchkin e a Intuição Heurística de Bazarian.}

V. N. Puchkin apresentou em seu livro Heurística: A Ciência do Pensamento Criador, no ano de 1969 a heurística em todas as suas vertentes, ou seja, desde a heurística nas atividades que permeiam os processos de construção do conhecimento científico, até a heurística como uma intuição capaz de prever e solucionar problemas comuns do dia-a-dia. Assim, no decorrer de toda sua obra, ele promove a importância da heurística como uma ciência articuladora do pensamento criador, capaz de desenvolver a capacidade humana para elaborar novas estratégias que conduzem à descoberta.

Para [30] "Pode ser designada pelo nome Heurística a Ciência que estuda as constantes da atividade do pensamento criador. Seus objetivos não se reduzem 
apenas as pesquisas das constantes do pensamento criador, mas compreendem também a elaboração de métodos e modos de direção dos processos heurísticos. Ultimamente, passaram também ao âmbito da heurística os trabalhos experimentais, através dos quais os cientistas cibernéticos procuram dar formas às manifestações superiores do intelecto humano" (PUCHKIN, 1969, pg. 8)

Neste sentido, ele considera que a atividade heurística é uma variável da mente humana que gera novos sistemas de ação, capazes de esclarecer os objetos desconhecidos que entornam a vida do homem. Além do mais, ele concorda com as idéias de Polya ao afirmar que o objetivo da heurística é a pesquisa de regras e métodos que levam às descobertas e às invenções.

Puchkin Ressalta ainda que "primordialmente, podemos definir a heurística como atividade humana que leva à solução de um problema atípico e que como heurísticos os específicos meios elaborados pelo homem no decorrer da solução de certos problemas que, mais ou menos conscientemente, são transferidos para outros problemas" (Puchkin 1969, pg. 18 - 19). E conclui afirmando que tal atividade é de ordem psicológica "sem embargo, como base desse novo e complexo ramo do conhecimento, que é a Heurística, aparece a Psicologia, principalmente sua parte denominada psicologia criadora ou pensamento produtivo". (Puchkin 1969, pg. 9)

Finalizando esse discurso sobre heurística, nos convém expor também as idéias de Jacob Bazarian, filósofo que definiu em seu livro, Intuição Heurística: uma análise heurística da intuição criadora, vários aspectos que permeiam o estímulo da criação de métodos capazes de resolver problemas, sejam de natureza cientifica ou não.

Para ele, "A intuição heurística é a musa da criatividade, da descoberta, da adivinhação e da solução de problemas. Quem conhecer o método de intuição heurística terá uma grande superioridade sobre os demais, sob todos os pontos de vista, tanto pessoal como profissional. E o principal - não será atormentado, nem aniquilado sob o peso de problemas não-solucionados." (BAZARIAN, 1986, pg. 28). Com isso, percebe-se a sua grande admiração pela intuição heurística, sendo ela determinante para o sucesso pessoal e/ou profissional.

Para entendermos melhor o porquê dessa sua reverência a intuição heurística, é fundamental compreendermos o significado que ele dá a esta intuição. Assim, [3] a define de duas maneiras "1) É uma forma de conhecimento direto, em que a solução de um problema prático ou teórico é encontrado de modo imediato, repentino, nãoconsciente e sem dados suficientes. 2) É um excelente meio ou método para descobrir ou adivinhar a verdade e pressentir ou achar a solução de problemas pessoais e profissionais que nos preocupam." (BAZARIAN, 1986, pg. 51). Para exemplificar 
2. As concepções de filósofos e/ou matemáticos acerca da abordagem heurística para o desenvolvimento do conhecimento

isso ele cita a descoberta de um dos princípios fundamentais da hidrostática feita por Arquimedes.

Bazarian, assim como Puchkin, define heurística como uma Ciência que relaciona-se diretamente com a criatividade, para ele, "heurística é a ciência do pensamento criador, o método ou a arte de descobrir ou adivinhar a verdade ou criar algo novo." (BAZARIAN, 1986, pg. 48). E conclui acrescentando também que “(...) em pedagogia, heurística é o método de ensino que leva o aluno a descobrir por si mesmo o que se pretende ensinar" (BAZARIAN, 1986, pg. 48).

Por fim, ele faz uma ressalva ao dizer que "Apesar de ser a mais rica operação da mente humana, a intuição heurística é a mais pobre em análise científica." (BAZARIAN, 1986, pg. 48) essa sua afirmação demonstra o caráter empírico, ou até mesmo "sobrenatural", que ele dá a intuição heurística.

Ao final deste capítulo, podemos concluir, através de uma análise dos discursos dos diversos autores citados, que a heurística como ciência é indispensável para o desenvolvimento do conhecimento, no nosso caso, o conhecimento matemático. Assim, essa compreensão nos dá embasamento necessário para prosseguir com a discussão acerca das potencialidades heurísticas trazidas pela não resolução dos três problemas clássicos da matemática, apenas com o uso dos instrumentos euclidianos. A partir de agora, passaremos a analisar a heurística no desenvolvimento da resolução destes três problemas de construção geométrica, tendo como base os as atividades heurísticas apontadas pelos autores estudados nesse capítulo. 


\section{CAPÍTULO 3}

\section{IDENTIFICANDO A HEURÍSTICA \\ COMO A CIÊNCIA DA PROCURA E \\ INVENÇÃO: SOLUÇÕES \\ ALTERNATIVAS PARA OS TRÊS \\ PROBLEMAS CLÁSSICOS DA \\ MATEMÁTICA GREGA}

Apesar de não ter conseguido encontrar soluções para os três problemas clássicos, usando apenas a régua não graduada e o compasso, os gregos não recuaram frente a estes problemas, muito pelo contrário, segundo [26], criam invenções sofisticadas que possibilitou soluções engenhosas.

Podemos dizer que a falta da solução, a partir da restrição imposta aos instrumentos citados, foi muito fértil para o desenvolvimento da matemática, possibilitando novos ramos de estudos, os quais são cruciais na atualidade. Uma das mais importantes dessas áreas de estudo são as curvas mecânicas, que foram protagonistas de várias soluções alternativas para estes três problemas.

De fato, os matemáticos gregos lidaram com três problemas, em cujas soluções se partia da premissa do uso apenas a régua sem escalas e o compasso, o que era algo bastante forte em sua tradição. As soluções de tais problemas segundo a expectativa 
mencionada não aconteceram, apesar de terem sido muito proativos nessa área, e de fato já se sabe que os três problemas são irresolúveis, existindo apenas soluções aproximadas. As provas desta impossibilidade de resolução podem ser encontradas em Freitas (2014, pg. 13 - 32).

A partir de então, assim como os atuais estudiosos da matemática, os matemáticos antigos abriram mão de tal premissa (usar apenas a régua não graduada e o compasso). Com isso, novas ideias surgiram e a procura por novas soluções proporcionou construções das mais variadas maneiras e formas, construções estas utilizadas até hoje.

Diante disso, podemos identificar que a busca por soluções para os três problemas clássicos resultou em grandes potencialidades heurísticas para a matemática. Assim, desenvolveremos esse capítulo exibindo algumas soluções alternativas encontradas pelos matemáticos gregos e a heurística por trás destas descobertas.

\subsection{Soluções para a duplicação do cubo}

Como já exposto no capítulo 1 o problema da duplicação do cubo consiste em construir apenas com régua não graduada e compasso a aresta de um cubo cujo volume seja o dobro de outro cubo dado. Digamos que a aresta de um cubo meça $x$, cujo volume é $x^{3}$, assim duplicá-lo consiste em encontrar a aresta de outro cubo, a designemos por $y$, de tal forma que $y^{3}=2 x^{3}$. Com isso, devemos encontrar uma aresta $y$ de comprimento $x \sqrt[3]{2}$.

Conforme [16] é bastante aceitável entre os historiadores que foi Hipócrates de Quios, que viveu em torno de 430 a. C. o primeiro matemático a expor uma tentativa de resolver esse problema, através da redução da duplicação do cubo ao problema de construção de meias proporcionais, isto é, médias proporcionais entre duas grandezas. Na simbologia atual, podemos dizer que Hipócrates pensou da seguinte maneira: Seja um cubo qualquer, cuja aresta meça $a$, então devemos encontrar dois segmentos $x$ e $y$, que são as chamadas meias proporcionais, de tal forma que $\frac{a}{x}=\frac{x}{y}=\frac{y}{b}$.

De fato, observe que das igualdades acima segue que $a b=x y, \log a^{2} b=a x y$ e $x^{2}=a y, \operatorname{assim} x^{3}=a x y$. A partir desses resultados segue que: $x^{3}=a x y=a^{2} b$, consequentemente, $\frac{x^{3}}{a^{3}}=\frac{a^{2} b}{a^{3}}$. Logo, $\frac{x^{3}}{a^{3}}=\frac{b}{a}$. Assim, observe que o cubo de aresta $x$ terá seu volume ampliado na proporção $\frac{b}{a}$. Para o caso particular em que $b=2 a$ teremos a duplicação do cubo, pois, $\frac{x^{3}}{a^{3}}=2, \operatorname{logo} x^{3}=2 a^{3}$. Isto é, o cubo de aresta $x$ tem volume duas vezes maior que o cubo de aresta $a$. 
Assim, fica fácil observar a equivalência feita por Hipócrates entre duplicar o cubo e encontrar duas meias proporcionais entre a aresta do cubo inicial e o seu dobro. Reduzindo assim, o problema a encontrar as duas meias proporcionais, $x$ e $y$, entre a aresta do cubo inicial, que chamemos de $a$, e o seu dobro, 2a. Muito possivelmente Hipócrates tenha feito essa descoberta a partir de uma analogia com o problema da duplicação do quadrado, que já tinha sido resolvido pelos gregos, inclusive apenas pelo uso dos instrumentos euclidianos, e que consistia em encontrar uma meia proporcional entre uma aresta e o seu dobro, mais detalhes sobre a duplicação do quadrado pode ser encontrado em Sousa ( 2001, pg. 53 - 55). No entanto, não se sabe ao exato se realmente foi este o motivo que o levou a fazer tal analogia.

Apesar do exposto, não existem documentos que comprovem que Hipócrates foi capaz de construir duas meias proporcionais entre a aresta de um cubo e o seu dobro, visto que tais construções necessitava de instrumentos mais sofisticados. No entanto, podemos afirmar que esta descoberta foi bastante eficaz para a solução do problema da duplicação do cubo, pois, quase todos os outros matemáticos que o sucedeu procuraram a solução do problema da duplicação do cubo focando em encontrar as duas meias proporcionais.

Assim, a analogia de Hipócrates é sem dúvida um exemplo das atividades heurísticas, utilizadas por ele, na busca de encontrar uma solução para a duplicação do cubo. Mesmo que ele não a tenha conseguido, outros matemáticos tornaram possível tal solução, como veremos a seguir.

\subsubsection{A provável solução de Platão}

Uma das primeiras soluções alternativas que apresentaremos aqui é a solução atribuída a Platão que foi um importante filósofo e matemático do final do século V e início do século IV a.C. Platão teria construído dois instrumentos conhecidos como a máquina de Platão e o esquadro de Platão, sua solução consistia em encontrar duas meias proporcionais entre dois segmentos dados. A seguir temos imagens desses instrumentos. 

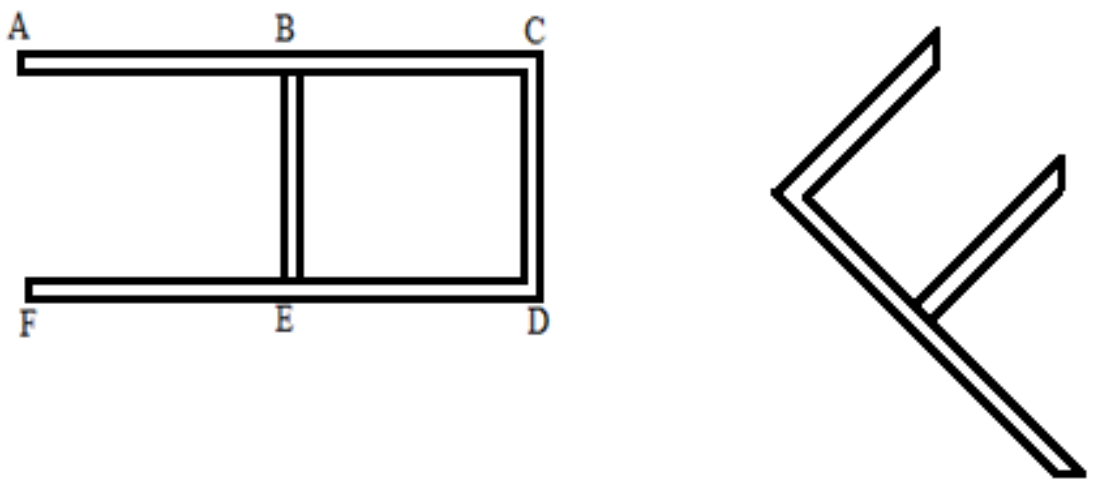

Como os dois instrumentos são muito semelhantes, provavelmente Platão tenha feito apenas um deles, já que ambos funcionam da mesma maneira, por isso limitaremos a explanar como é feito apenas a maquina de Platão. Como pode ser observado na primeira figura acima, este instrumento é um objeto rígido $A C D F$, onde os segmentos $\overline{A C}$ e $\overline{F D}$ são paralelos e o segmento $\overline{C D}$ perpendicular a $\overline{A C}$ e $\overline{F D}$, estes três segmentos são fixos. O último segmento, $\overline{B E}$, é móvel, paralelo ao segmento $\overline{C D}$ e pode deslizar ao longo dos segmentos $\overline{A C}$ e $\overline{F D}$, sempre perpendicular a ambos.

Assim, para construir as meias proporcionais, procede-se da seguinte maneira: Traça-se duas retas perpendiculares que se interceptam em um ponto, digamos $O$, entre as quais desejamos construir as duas meias proporcionais. Marca-se em uma das retas o ponto $P$ e na outra o ponto $M$, de tal forma que $\overline{O M}=2 \overline{O P}$. Tomemos $\overline{O P}=$ a como sendo a aresta do cubo que desejamos duplicar o volume, assim $\overline{O M}=2 a$. Em seguida, manipula-se a maquina de modo que o segmento fixo $\overline{C D}$ passe pelo ponto $M$, o ponto $C$ esteja exatamente sobre a reta horizontal e desliza-se o segmento móvel $\overline{B E}$ até que ele passe pelo ponto $P$ e o ponto $B$ esteja exatamente sobre a reta da vertical, conforme figura a seguir.

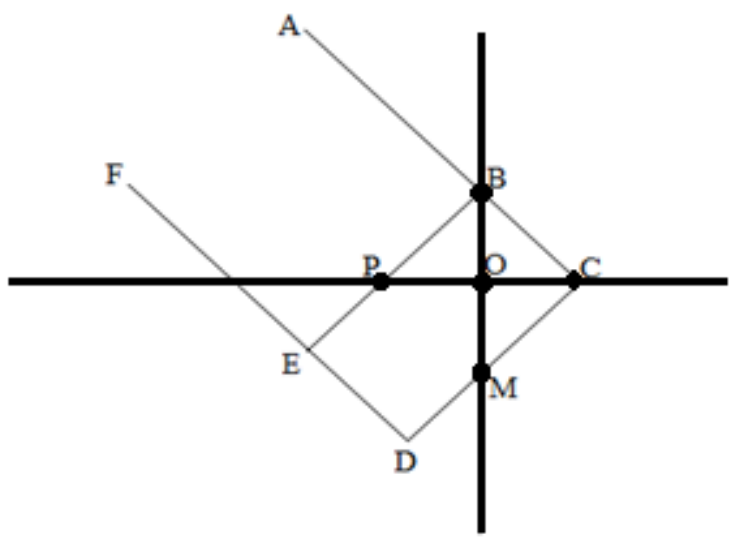


Com isso, teremos três triângulos $P O B, B O C$ e $C O M$. Os ângulos $P \hat{O} B, B \hat{O} C$ e $C \hat{O} M$ são retos, por construção $C \hat{B} O+P \hat{B} O=90^{\circ}$ e $B \hat{C} O+C \hat{B} O=90^{\circ}$, logo $P \hat{B} O=B \hat{C} O$. Além disso, $B \hat{C} O+O \hat{C} M=90^{\circ}$ e $C \hat{M} O+O \hat{C} M=90^{\circ}, \log 0$ $B \hat{C} O=C \hat{M} O$. Assim, segue que $P \hat{B} O=B \hat{C} O=C \hat{M} O$, logo os três triângulos terão os mesmos ângulos, por isso eles serão semelhantes. Portanto, teremos pela semelhança de triângulos: $\frac{\overline{O P}}{\overline{O B}}=\frac{\overline{O B}}{\overline{O C}}=\frac{\overline{O C}}{\overline{O M}}$. Como tomamos $\overline{O P}=a$ e $\overline{O M}=2 a$, então $\frac{a}{\overline{O B}}=\frac{\overline{O B}}{\overline{O C}}=\frac{\overline{O C}}{2 a}$. Dessa forma, temos que os segmentos $\overline{O B}$ e $\overline{O C}$ são as meias proporcionais entre $a$ e $2 a$ e o segmento $\overline{O B}$ é aresta do cubo que tem o dobro do volume do cubo de aresta $a$. Logo esse instrumento resolve o problema da duplicação do cubo, é claro que sem uso apenas da régua não graduada e compasso, já que a construção da máquina de Platão requer o uso de outros instrumentos.

Alguns historiadores apontam que esta solução não é de Platão, pois ele evitava utilizar soluções mecânicas. No entanto, este instrumento é remetido a Platão graças a Eutócio de Ascalão (480 - 540), matemático grego que escreveu alguns comentários sobre Arquimedes e Apolônio. Para D'acampora (2014, pg. 49) "Existem indícios, numa citação de Eutócio, que Platão, tivesse encontrado uma solução mecânica para a duplicação do cubo, através da inserção de dois meios proporcionais. Porém, há também contradições sobre esta autoria pelo fato de Platão rejeitar soluções mecânicas, sob o argumento de destruir a virtuosidade da geometria. Podendo ainda a solução ter sido encontrada por seus discípulos."

Sendo feito ou não por Platão, o importante é que esse instrumento possibilitou uma solução alternativa para o problema da duplicação do cubo. Como podemos observar, é uma solução simples e que esclarece como encontrar duas meias proporcionais entre dois segmentos dados. Assim, podemos dizer que o potencial heurístico dessa solução encontra-se exatamente na máquina de Platão (ou esquadro de Platão), pois é uma ferramenta inovadora que possibilita uma solução simples e eficaz para o problema.

\subsubsection{As duas soluções de Menecmo}

Menecmo (380 - 320 a.C.) foi um matemático geômetra da Grécia antiga. Seu nome está relacionado aos estudos das curvas obtidas pela interseç̧ão de um cone reto de base circular com um plano perpendicular a reta geratriz, estas curvas são chamadas de cônicas, que são a elipse, a parábola e a hipérbole.

As suas soluções também consiste em determinar duas meias proporcionais entre os segmentos $a$ e $2 a$, isto é, $\frac{a}{x}=\frac{x}{y}=\frac{y}{2 a}$. Assim, teremos que $x^{2}=a y, \log 0$ $y=\frac{1}{a} x^{2} ; y^{2}=2 a x$, isto é, $x=\frac{1}{2 a} y^{2}$ e $x y=2 a^{2}$. Desse modo, podemos obter o 
segmento $x$ de duas formas. A primeira como a abscissa do ponto de intersecção da parábola $y=\frac{1}{a} x^{2}$, com a parábola $x=\frac{1}{2 a} y^{2}$. A segunda como a abscissa do ponto de intersecção da parábola $y=\frac{1}{a} x^{2}$ com a hipérbole equilátera $x y=2 a^{2}$.

Essas são as duas soluções de Menecmo e, é fácil ver, que em ambos os casos teremos que $x^{3}=2 a^{3}$, isto é, $x$ é a aresta do cubo que tem volume duas vezes maior que o cubo de aresta $a$. Os gráficos a seguir mostram os dois pontos de intersecção cujas coordenadas são as meias proporcionais procuradas.
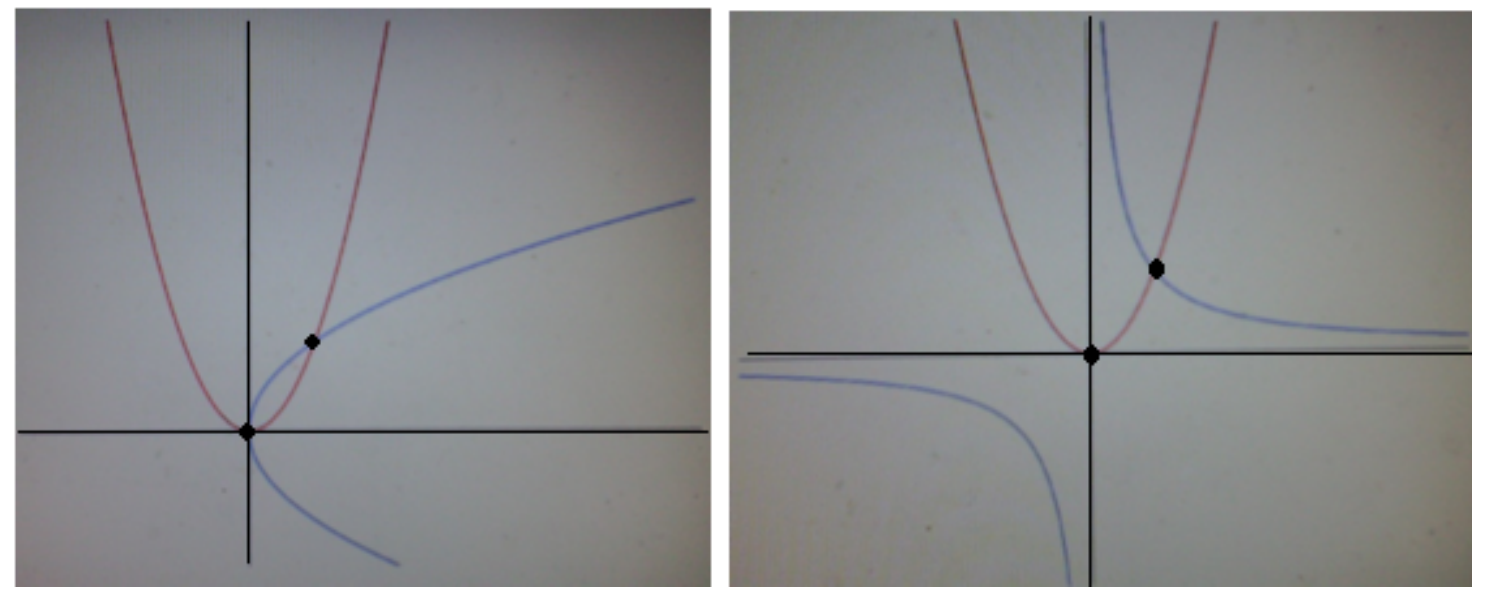

Como podemos observar, fazendo o uso da geometria analítica que temos hoje, fica bastante simples encontrar os pontos de intersecção entre as parábolas e a parábola e a hipérbole, no entanto, a geometria analítica só veio a ter seu desenvolvimento com René Descartes, no século XVII. Sendo assim, encontrar estes pontos de intersecção na época de Menecmo era uma tarefa árdua, o que lhe requeria um conhecimento detalhado sobre as propriedades das cônicas.

Estas soluções de Menecmo representam um importante avanço no estudo das cônicas. Para Souza (2001, pg. 65) "As descobertas de Menecmo advieram da sua procura de uma solução para o problema da duplicação do cubo, mais propriamente, da procura de curvas que possuíssem as propriedades adequadas à resolução do problema de encontrar os dois meios proporcionais da redução de Hipócrates." Isso nos mostra mais um benefício gerado pelo problema da duplicação do cubo. De fato, abrir mão da restrição a régua e ao compasso foi algo bastante frutífero para a matemática.

\subsubsection{A solução feita por Eratóstenes}

Eratóstenes de Cirene, além de nos ter transmitido uma das lendas para o problema da duplicação do cubo, ainda resolveu este problema por meio de uma 
máquina mecânica conhecida como o Mesolábio. Tal solução também consistia em encontrar duas meias proporcionas entre dois segmentos de reta $a$ e $2 a$.

Esta máquina consiste em uma base retangular rígida $A B C D$ e de três triângulos retângulos congruentes, que estão presos nas bases do retângulo $A B C D$, conforme figura a seguir. Um dos três triângulos é fixo e os outros dois podem deslizar paralelos a si mesmos e pode haver também sobreposições dos triângulos, totais ou parciais.

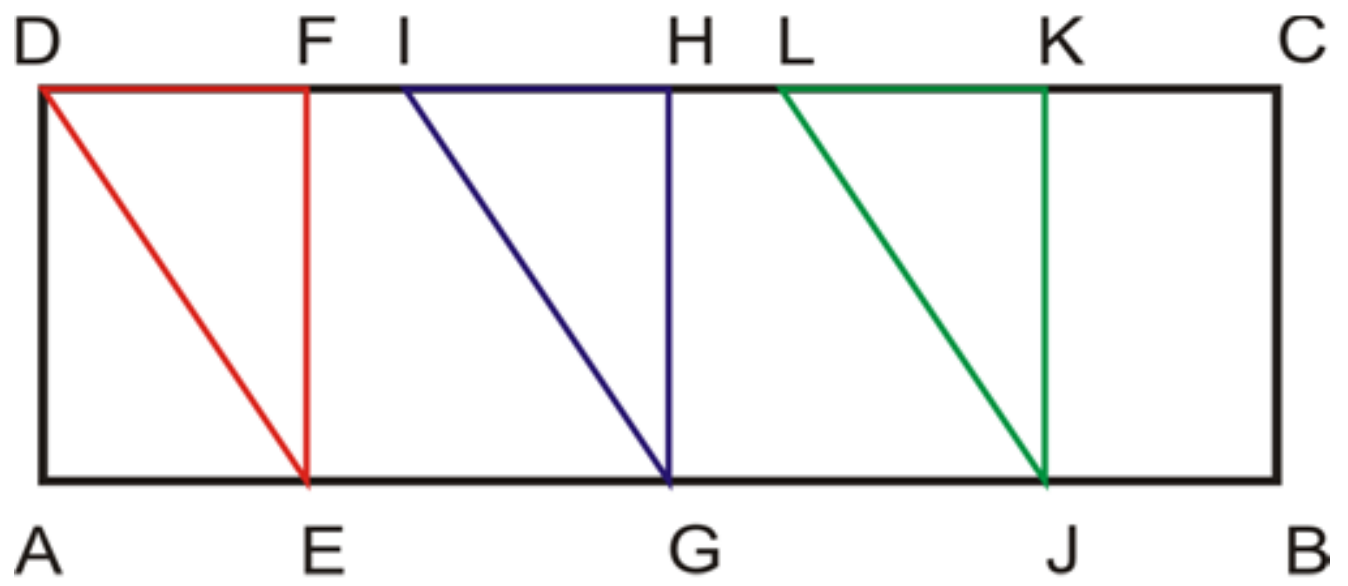

Para encontrar as meias proporcionais entre $a$ e $2 a$, primeiro vamos considerar o lado $\overline{A D}=2 a$, isto é, o lado $A D$ será o dobro do lado do segmento a, que é a aresta do cubo que desejamos duplicar o volume. Em seguida, marquemos o ponto médio $M$ do segmento $\overline{K J}$ que é um lado do triângulo $L K J$, deixemos o triângulo $D F E$ fixo e movimentemos os outros dois de tal forma que o ponto $O$ de intersecção do segmento $\overline{F E}$ com o segmento $\overline{I G}$, o ponto $N$ de intersecção do segmento $\overline{L J}$ com o segmento $\overline{H G}$ e o ponto $M$ estejam em uma mesma reta, ou seja, sejam colineares, conforme figura a seguir:

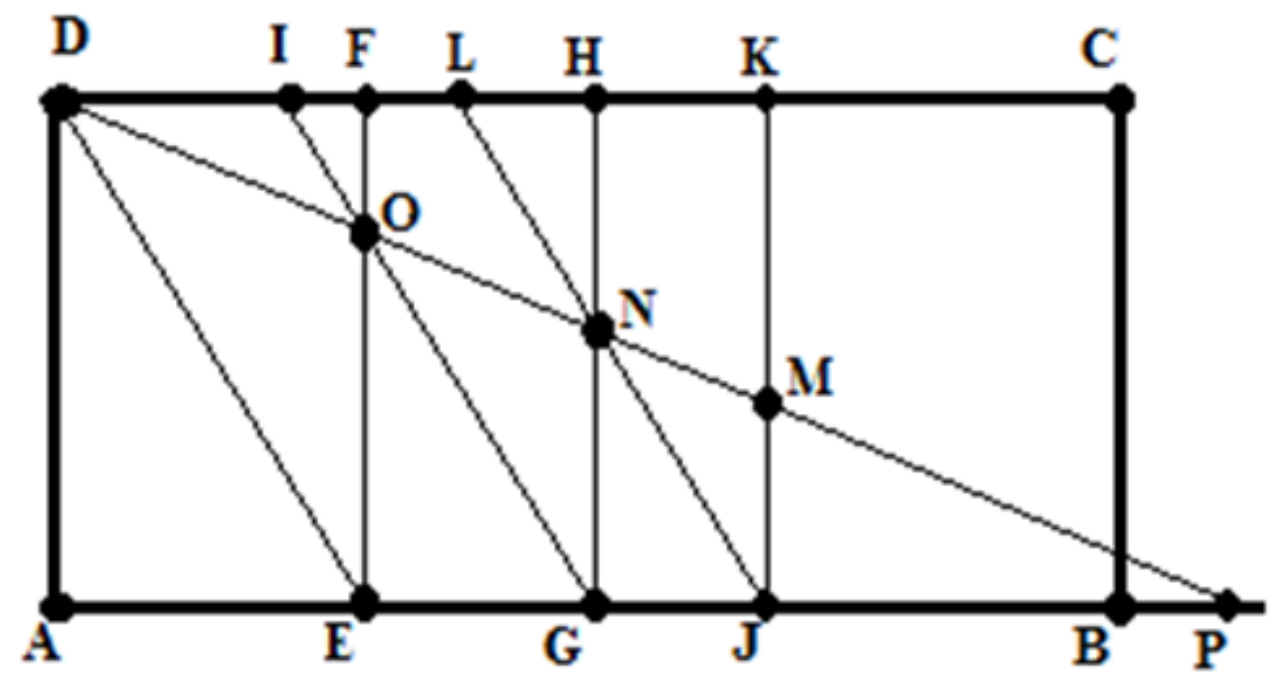

Assim, segue que os segmentos $\overline{O E}$ e $\overline{N G}$ são as meias proporcionais entre $a=\overline{M J}$ e $2 a=\overline{D A}$. De fato, como temos que $\overline{A B} / / \overline{C D}$, que $\overline{E F} / / \overline{G H}$ 
/ / $\overline{J K}$ e por esses segmentos serem perpendiculares a $\overline{A B}$, portanto, segue que os triângulos $D A P, O E P, N G P$ e $M J P$, por terem ângulos correspondentes iguais, então serão semelhantes. Por isso:

$$
\frac{\overline{O E}}{\overline{D A}}=\frac{\overline{E P}}{\overline{A P}}=\frac{\overline{O P}}{\overline{D P}} ; \frac{\overline{N G}}{\overline{O E}}=\frac{\overline{G P}}{\overline{E P}}=\frac{\overline{N P}}{\overline{O P}} ; \frac{\overline{M J}}{\overline{N G}}=\frac{\overline{J P}}{\overline{G P}}=\frac{\overline{M P}}{\overline{N P}}
$$

Agora observe que, por construção, $\overline{D E} / / \overline{I G} / / \overline{L J}$. Assim, os triângulos $D E P, O G P$ e $N J P$, também por terem ângulos correspondentes iguais, serão semelhantes, consequentemente:

$$
\frac{\overline{O G}}{\overline{D E}}=\frac{\overline{G P}}{\overline{E P}}=\frac{\overline{O P}}{\overline{D P}} ; \frac{\overline{N J}}{\overline{O G}}=\frac{\overline{J P}}{\overline{G P}}=\frac{\overline{N P}}{\overline{O P}}
$$

Logo de 3.1 e 3.2 segue que:

$$
\frac{\overline{O E}}{\overline{D A}}=\frac{\overline{E P}}{\overline{A P}}=\frac{\overline{O P}}{\overline{D P}}=\frac{\overline{O G}}{\overline{D E}}=\frac{\overline{G P}}{\overline{E P}}=\frac{\overline{N G}}{\overline{O E}}=\frac{\overline{N P}}{\overline{O P}}=\frac{\overline{N J}}{\overline{O G}}=\frac{\overline{J P}}{\overline{G P}}=\frac{\overline{M P}}{\overline{N P}}=\frac{\overline{M J}}{\overline{N G}}
$$

Daí, a parte que nos interessa é $\frac{\overline{M J}}{\overline{N G}}=\frac{\overline{N G}}{\overline{O E}}=\frac{\overline{O E}}{\overline{D A}}$ e como tomamos, $a=\overline{M J} \mathrm{e}$ $2 a=\overline{D A}$, então, $\frac{a}{\overline{N G}}=\frac{\overline{N G}}{\overline{O E}}=\frac{\overline{O E}}{2 a}$. Logo, $\overline{N G}$ e $\overline{O E}$ são as meias proporcionais entre $a$ e $2 a$, por isso, $\overline{N G}$ é a aresta do cubo, cujo volume tem o dobro do volume do cubo de aresta $a$.

Observamos nesta solução um invento simples, mas de aplicabilidade extraordinária para encontrar as meias proporcionais. Temos, dessa forma, mais uma solução alternativa para o problema da duplicação do cubo e mais um exemplo do potencial heurístico para a matemática, proporcionado por tal problema

\subsubsection{A solução tridimensional de Arquitas}

Uma das mais belas soluções alternativas para o problema da duplicação do cubo é sem dúvida a solução tridimensional atribuída a Arquitas de Tarento que foi um matemático do sec. IV a.C. A maioria dos historiadores consideram esta solução uma das mais antigas, como aponta Sousa (2001, pg. 57) "Arquitas de Tarento, geômetra do século IV a.C, é o autor da mais antiga solução para o problema da duplicação do cubo, da qual temos conhecimento através de uma passagem de Eudémio de Rodes reproduzida nos escritos de Eutócio."

[18] também considerada a beleza desta solução ao afirmar que "A solução de Arquitas é a mais notável de todas, especialmente quando sua data é considerada (primeira metade do séc IV a.C.) porque não é nenhuma construção plana, mas 
uma corajosa construção em três dimensões, determinando um certo ponto como a intersecção de três superfícies de revolução (...)"(HEATH, 1981)

Essa construção de Arquitas, também consiste em determinar duas meias proporcionais entre $a$ e $2 a$ e se baseia em encontrar um certo ponto que é obtido pela intersecção de três superfícies de revolução: um cone reto, um cilindro e um toro. Para Santana (2013, pg. 14) "A curva de Arquitas é obtida com a interseção do toro e do cilindro enquanto o ponto procurado é encontrado com a interseção desta curva com o cone."

De fato, para compreendermos melhor esta solução faremos o uso da moderna geometria analítica, a qual Arquitas não teve conhecimento. Para tanto, seja um cubo qualquer, cuja aresta meça $a$, o qual pretendemos duplicar. Além disso, seja o ponto $(a, 0,0)$ o centro de três círculos mutuamente ortogonais, de raio medindo $a$ e cada um destes círculos situados em um plano perpendicular a um eixo coordenado. Conforme figura abaixo:

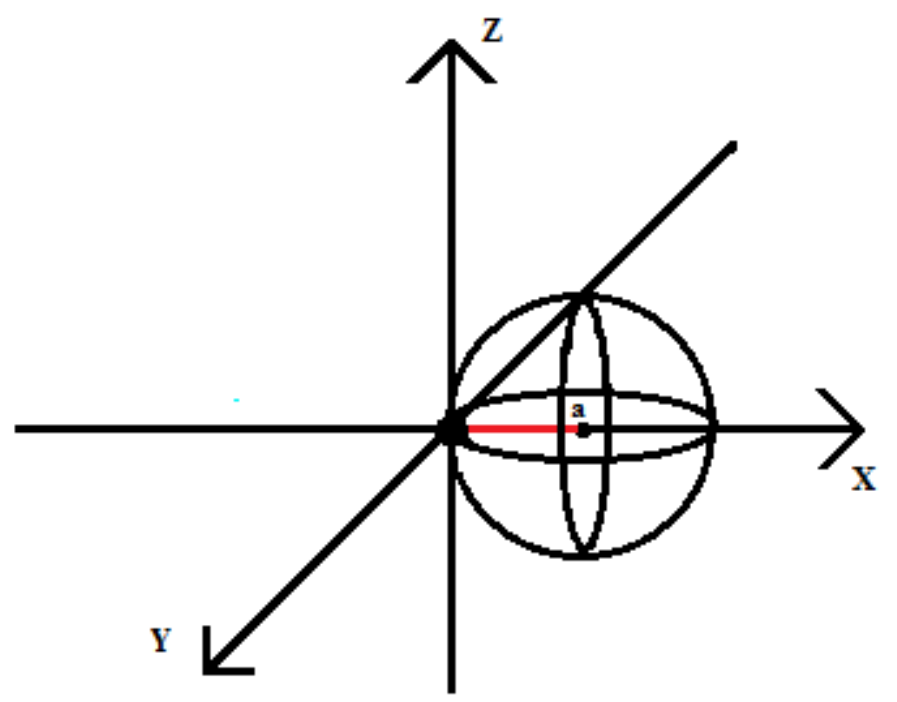

Em seguida, sobre o círculo perpendicular ao eixo $0 X$, construímos um cone circular com vértice na origem, $A=(0,0,0)$ e de raio da base $a \sqrt{3}$, cuja equação é

$$
x^{2}+y^{2}+z^{2}=\frac{b^{2}}{a^{2}} x^{2} .
$$

Conforme a seguinte figura: 


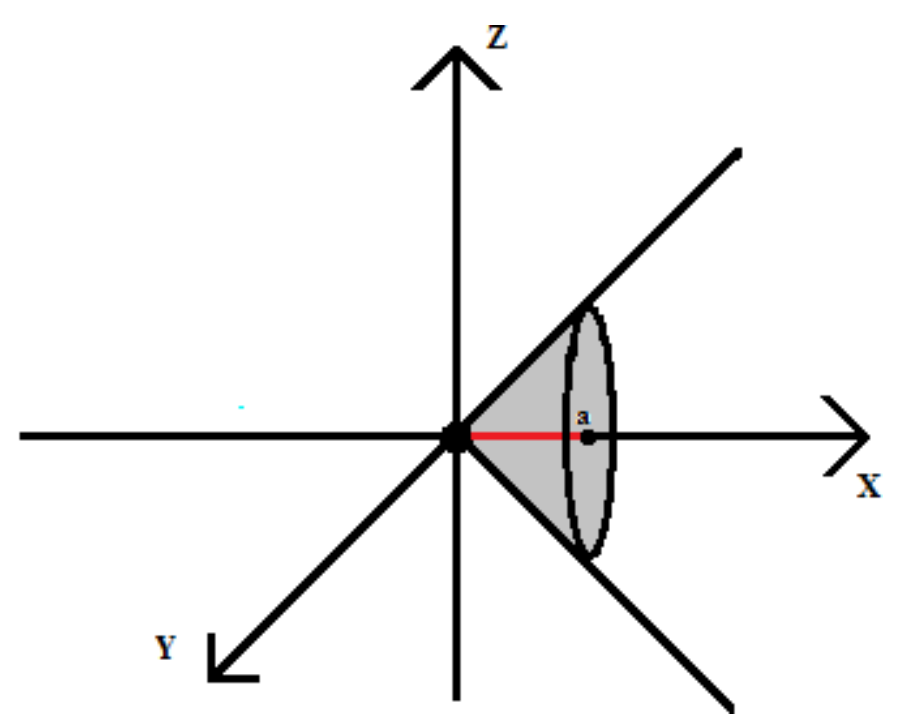

Logo após, sobre o círculo no plano $X Y$ construímos um cilindro circular reto de raio de base $r=a$ e centro em $(a, 0,0)$, cuja equação é

$$
x^{2}+y^{2}=b x
$$

Conforme figura a seguir:

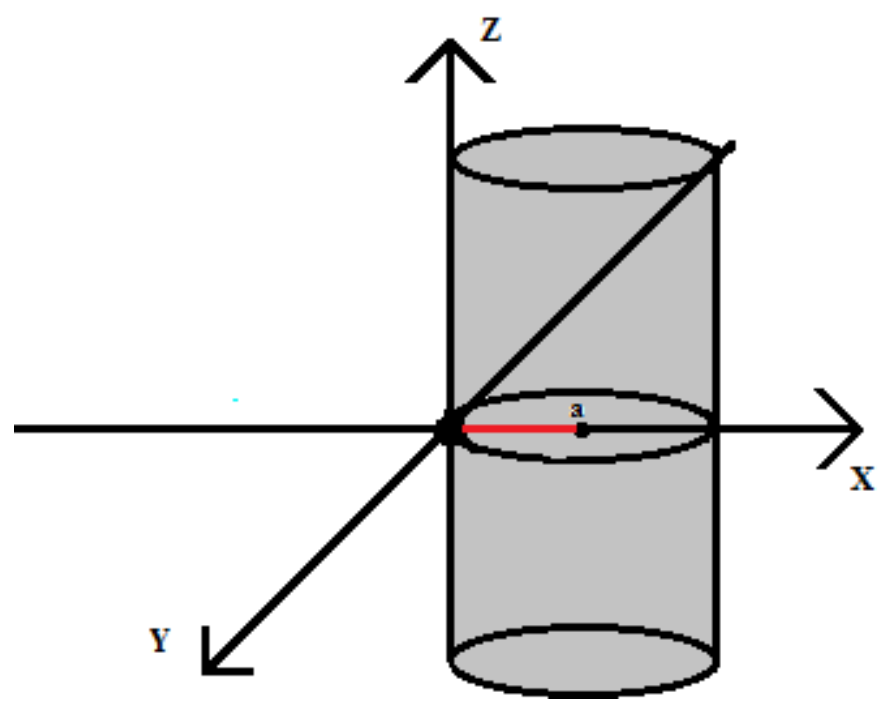

Por último, no plano $X Z$ giramos o círculo em torno do eixo $0 Z$ gerando um toro, cuja equação é

$$
x^{2}+y^{2}+z^{2}=b \sqrt{\left(x^{2}+y^{2}\right)} .
$$

Como mostra a seguinte figura: 
3. Identificando a Heurística como a ciência da procura e invenção: soluções alternativas para os três problemas clássicos da matemática grega

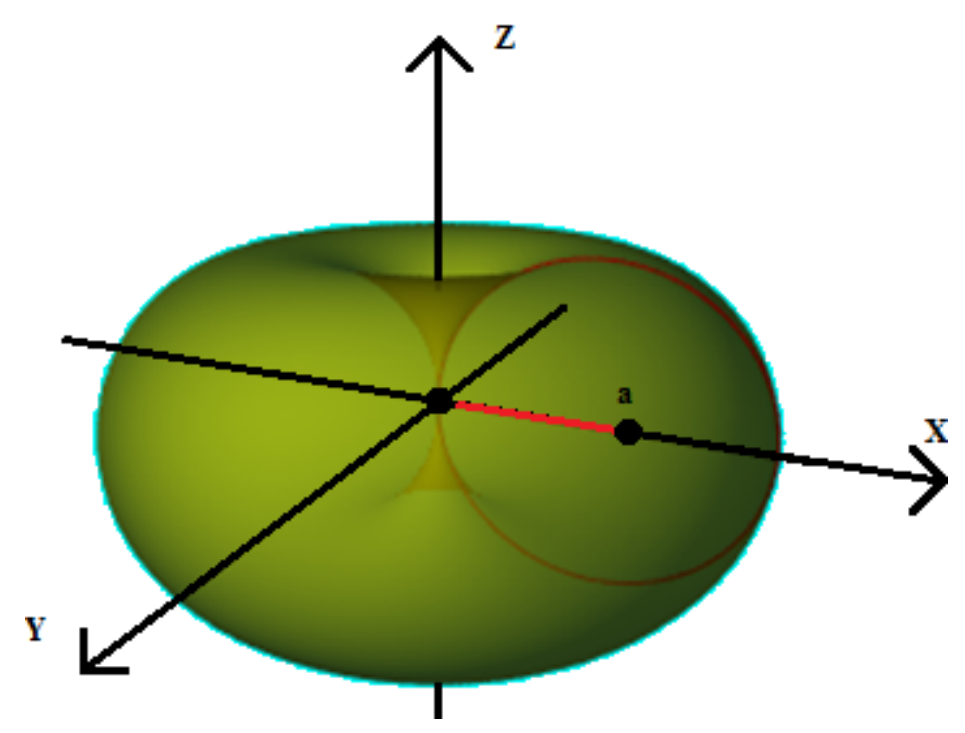

Na figura a seguir podemos ver o ponto de intersecção dessas três superfícies de revolução.

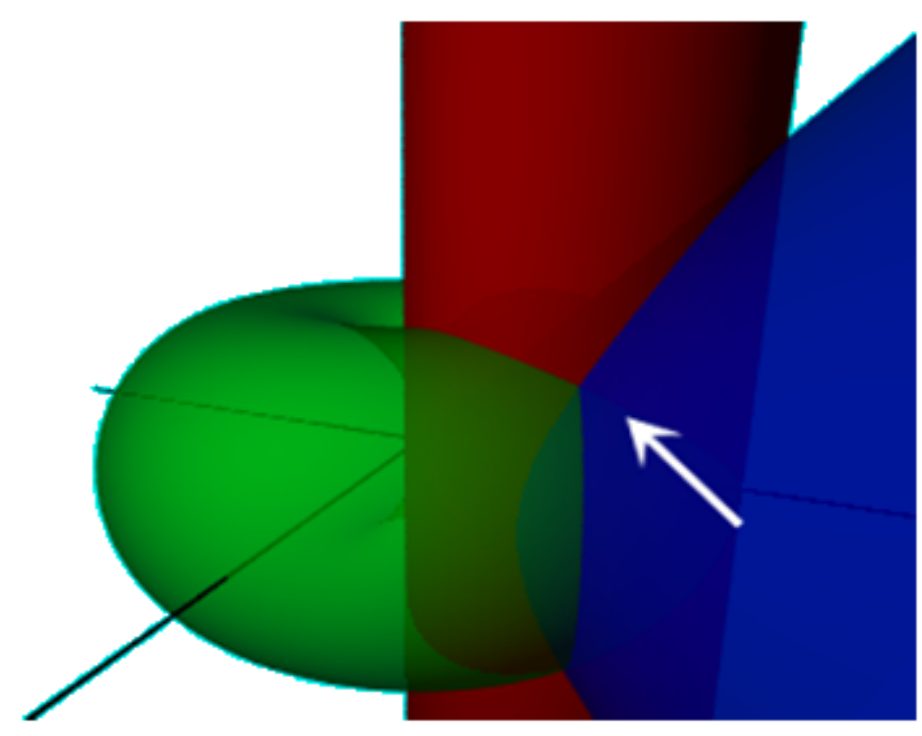

Fonte: Ricardo Bittencourt

Levando em conta o fato de que para a duplicação do cubo deveremos ter necessariamente $b=2 a$, assim, faremos a intersecção destas três superfícies.

Observe que a equação do toro $x^{2}+y^{2}+z^{2}=b \sqrt{x^{2}+y^{2}}$ também pode ser escrita da seguinte maneira: $\left(\sqrt{x^{2}+y^{2}+z^{2}}\right)^{2}=b \sqrt{x^{2}+y^{2}}$. Daí segue que: $\left(\sqrt{x^{2}+y^{2}+z^{2}}\right)\left(\sqrt{x^{2}+y^{2}+z^{2}}\right)=b \sqrt{x^{2}+y^{2}}, \log \mathrm{o}$

$$
\frac{\sqrt{x^{2}+y^{2}+z^{2}}}{\sqrt{x^{2}+y^{2}}}=\frac{b}{\sqrt{x^{2}+y^{2}+z^{2}}} .
$$


Agora, substituindo a equação do cilindro (3.5), na equação do cone (3.4), teremos que: $x^{2}+y^{2}+z^{2}=\left(\frac{b^{2}}{a^{2}}\right)\left(\frac{x^{2}+y^{2}}{b}\right)^{2}$, então $x^{2}+y^{2}+z^{2}=\left(\frac{b^{2}}{a^{2}}\right)\left(\frac{\left(x^{2}+y^{2}\right)^{2}}{b^{2}}\right)$, $\log \mathrm{O}$

$$
x^{2}+y^{2}+z^{2}=\frac{\left(x^{2}+y^{2}\right)^{2}}{a^{2}}
$$

Assim, $x^{2}+y^{2}+z^{2}=\left(\frac{x^{2}+y^{2}}{a}\right)^{2}$, então $\sqrt{x^{2}+y^{2}+z^{2}}=\frac{x^{2}+y^{2}}{a}$. De (3.8) ainda podemos obter: $x^{2}+y^{2}+z^{2}=\frac{\left(x^{2}+y^{2}\right)\left(x^{2}+y^{2}\right)}{a^{2}}$, logo: $\frac{x^{2}+y^{2}+z^{2}}{x^{2}+y^{2}}=\frac{x^{2}+y^{2}}{a^{2}}$, então,

$$
\frac{\sqrt{x^{2}+y^{2}+z^{2}}}{\sqrt{x^{2}+y^{2}}}=\frac{\sqrt{x^{2}+y^{2}}}{a}
$$

Agora de 4.2 e 3.9 obtemos que

$$
\frac{b}{\sqrt{x^{2}+y^{2}+z^{2}}}=\frac{\sqrt{x^{2}+y^{2}+z^{2}}}{\sqrt{x^{2}+y^{2}}}=\frac{\sqrt{x^{2}+y^{2}}}{a}
$$

Como estamos considerando um sistema de eixos coordenados, onde tomemos a origem do sistema como sendo o ponto $A=(0,0,0)$, então vamos considerar o ponto $k$, como sendo a intersecção das três superfícies de revolução. Assim, obviamente as coordenadas de $K$ serão $(x, y, z)$. Consequentemente, $\overline{A K}$ (distância da origem ao ponto $K$ ) será dada por $\overline{A K}=\sqrt{x^{2}+y^{2}+z^{2}}$ e tomando o ponto $B$ como sendo a projeção do ponto $K$ no eixo $X Y$, então $B$ tem coordenadas $(x, y)$, consequentemente, $\overline{A B}$ (distância da origem ao ponto $B$ ) será dada por $\overline{A B}=\sqrt{x^{2}+y^{2}}$.

Assim, teremos de 3.10 que $\frac{b}{\overline{A K}}=\frac{\overline{A K}}{\overline{A B}}=\frac{\overline{A B}}{a}$ e como consideramos $b=2 a$, então: $\frac{2 a}{\overline{A K}}=\frac{\overline{A K}}{\overline{A B}}=\frac{\overline{A B}}{a}$. Logo, os segmentos $\overline{A K}$ e $\overline{A B}$ são as meias proporcionais entre $a$ e $2 a$, com isso, o cubo de aresta $\mathrm{AB}$ tem o volume duas vezes maior que o cubo de aresta $a$.

De fato, Arquitas inventou uma solução fabulosa que é essencialmente abstrata, algo bastante avançado para a época. [40] considera fantástica tal solução ao afirmar que "Isso é admirável. Arquitas deve ter tido realmente uma inspiração divina quando achou esta construção." (van der WAERDEN, pg. 151)

Assim, podemos perceber a presença de métodos heurísticos na solução tridimensional de Arquitas, que é dada pela intersecção de três superfícies de revolução. Esta atividade heurística pode ser identificada quando ele utiliza os movimentos mecânicos em soluções de problemas de geometria, conforme Sousa (2001, pg. 57) "A solução proposta por Arquitas, além de ser uma solução de extrema beleza geométrica, revela uma excelente inovação por parte deste 
matemático, nomeadamente por utilizar movimentos mecânicos na solução de um problema geométrico." O que vem a enfatizar as potencialidades heurísticas desse problema para a matemática, pois, esse engenho pode proporcionar o início dos estudos sobre as curvas reversas. Para [36]:

Esta solução é muito engenhosa e tem grande interesse histórico, porque é o mais antigo exemplo de solução de um problema de geometria plana usando geometria espacial, e a curva usada é a mais antiga curva reversa conhecida. (TEIXEIRA, 1995, pg. 290)

\subsubsection{A solução de Nicomedes - a conchóide}

Existem poucas fontes de informações sobre a vida de Nicomedes, mas é muito provável que ele tenha vivido por volta de 240 a.C, em uma época posterior a de Eratóstene de Cirene. Ele foi um famoso geômetra e nos deixou importantes inventos matemáticos, como por exemplo, a conchóide que é uma curva mecânica que serve tanto para resolver a duplicação do cubo como também o problema da trissecção do ângulo.

A conchóide é uma curva no formato de uma concha que possui propriedades específicas. Para construí-la tracemos uma reta $r$ e um ponto fixo $O$, exterior a $r$. Em seguia, tomamos um ponto $P$ que pertence a reta $r$ e outro ponto $Q$ pertencente ao prolongamento do segmento $O P$, cujo comprimento fixo é $K=\overline{P Q}$. Assim, a conchóide é o lugar geométrico do ponto $Q$ quando $P$ se move ao longo da reta $r$ para o pólo $O$. Conforme imagem a seguir:

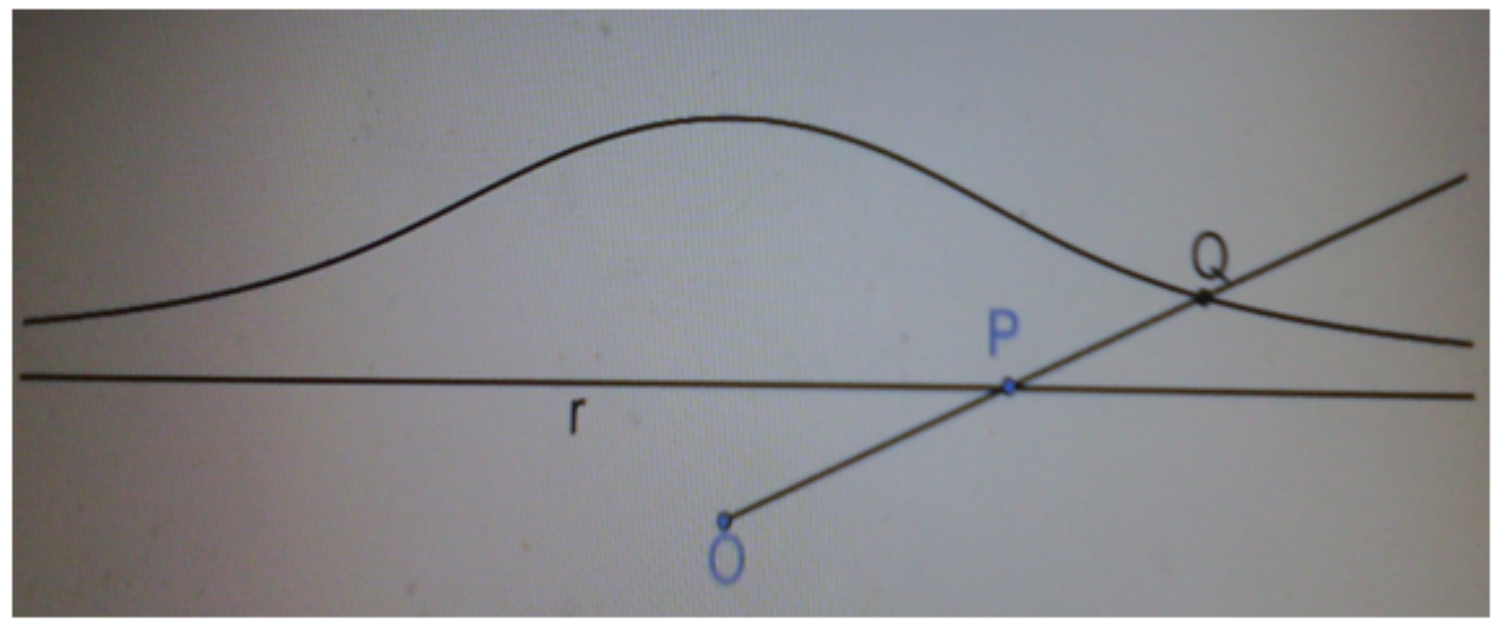

Mais detalhes sobre a definição e como construir a conchóide pode ser encontrado em Sousa (2001, pg. 33 - 36) e Ferreira (2011, pg. 202 - 204). Esta curva tem uma 
propriedade especial que é a base de sua definição, onde qualquer reta que parte do pólo $O$ e que intercepta a reta $r$ e em seguida a curva, tem a distância constante entre estes pontos de intersecção.

Mostraremos agora uma construção a partir da conchóide que tornará possível encontrar as duas meias proporcionais, assim como aquelas apresentadas anteriormente. Logo, para inserir duas meias proporcionais entre $\overline{A B}=b$ e $\overline{B C}=a$, traçaremos o retângulo $A B C D$. Seja $E$ o ponto médio de $\overline{A B}$ e tracemos a reta que passe por $D$ e $E$ intersectando a reta que passa por $C$ e $B$ em um ponto $G$. Seja $F$ o ponto médio de $\overline{B C}$ e tracemos uma perpendicular a $\overline{B C}$ passando por $F$ e marquemos o ponto $H$ de tal modo que $\overline{A E}=\overline{C H}$. Em seguida, tracemos uma reta que passa por $H$ e $G$ e uma paralela a $\overline{H G}$ que passe por $C$, a qual designaremos por $\overline{C I}$.

Assim, construamos a conchoide que tem $H$ como pólo, $\overline{C I}$ como régua e a distância igual a $\overline{C H}=\overline{A E}$. Dessa forma, um dos ramos desta conchoide encontra o prolongamento da reta $\overline{B C}$ em um ponto que chamaremos de $J$. Unamos $H J$ e pelas propriedades da conchoide teremos que $\overline{I J}=\overline{C H}=\overline{A E}$. Por fim, tracemos a reta que passa por $J$ e $D$ encontrando o Prolongamento da reta $\overline{A B}$ em um ponto que designaremos por $K$. Conforme figura abaixo:

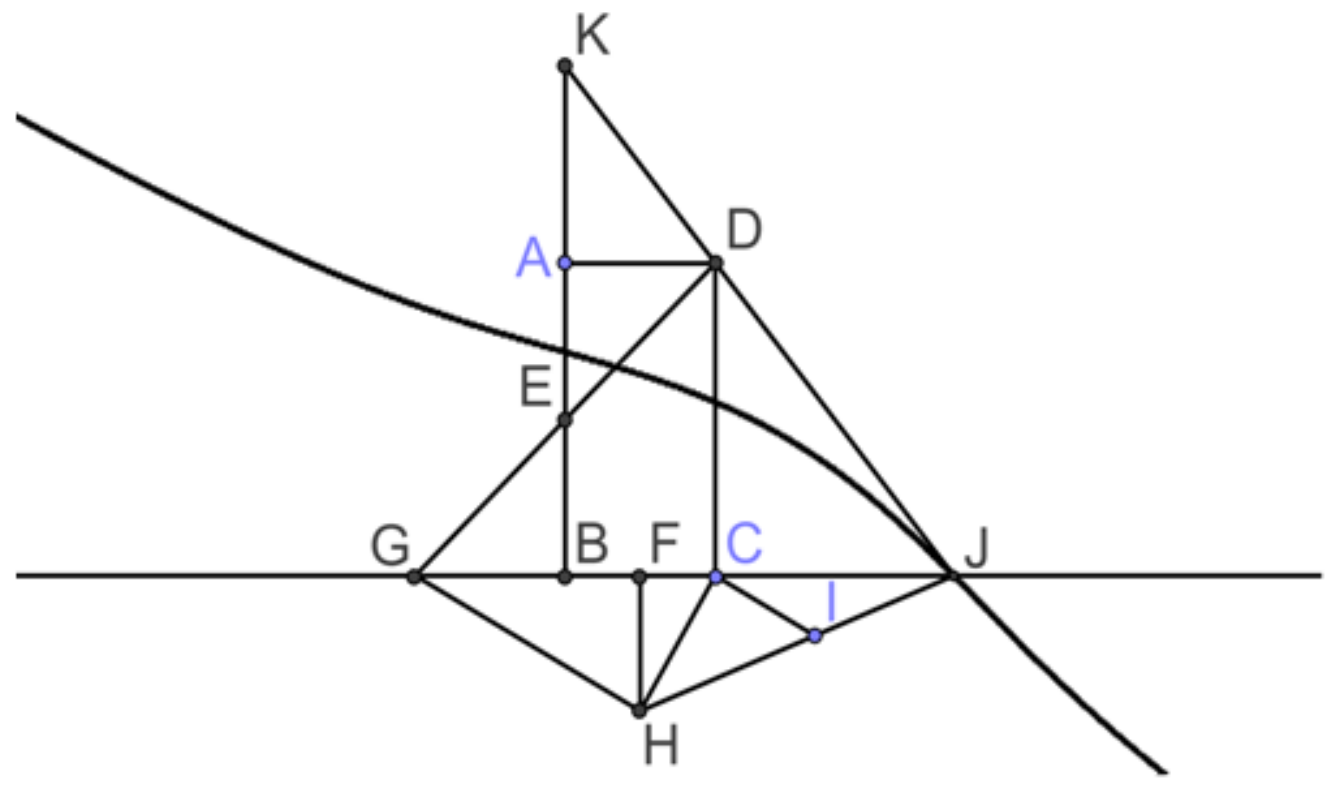

Dessa construção segue que $\overline{C J}$ e $\overline{K A}$ são as meias proporcionais entre $\overline{A B}=b$ e $\overline{B C}=a$, isto é, $\frac{\overline{A B}}{\overline{C J}}=\frac{\overline{C J}}{\overline{K A}}=\frac{\overline{K A}}{\overline{B C}}$ e quando $\overline{B C}=2 \overline{A B}$, temos que $\frac{b}{\overline{C J}}=\frac{\overline{C J}}{\overline{K A}}=\frac{\overline{K A}}{2 b}$. A demonstração detalhada dessa afirmação pode ser encontrada em d'Acampora (2014, pg. 53 - 57) e Sousa (2001, pg. 75 - 77).

Esta curva mecânica, inventada por Nicomedes, é mais um exemplo heurístico do problema da duplicação do cubo, que muito possivelmente fertilizou a mente 
deste geômetra a buscar uma solução alternativa para o referido problema. Van der Waerden (1983, pg. 237) exalta a capacidade criativa de Nicomedes ao afirmar que “(...) é de admirar o talento de Nicomedes, que descobriu não só a prova mas a construção em si."

\subsubsection{A solução de Diocles - a cissóide}

Diócles de Caristos (240 a.C. a 180 a.C.) foi um matemático geômetra grego que também resolveu o problema da duplicação do cubo usando uma curva mecânica, a qual é chamada atualmente de cissóide. Sua solução também consiste em encontrar as duas meias proporcionais.

De modo geral uma cissóide é uma curva determinada da seguinte forma: "Dadas $C 1$ e $C 2$ duas curvas quaisquer, $A$ um ponto fixo e uma reta passando por $A$ e intersectando $C 1$ e $C 2$ em $Q$ e $R$, respectivamente. Determina-se $P$, sobre a reta traçada, tal que $\overline{A P}=\overline{Q R}$. O lugar geométrico descrito por $P$ é a cissóide de $C 1 \mathrm{e}$ $C 2$ relativa ao ponto $A$." d'Acampora (2014, pg. 57 - 58)

Na cissóide de Diócles as duas curvas envolvidas era uma circunferência e uma linha reta tangente a circunferência, cujo ponto fixo é o ponto diametralmente oposto ao ponto de tangência, como mostra a figura a seguir:

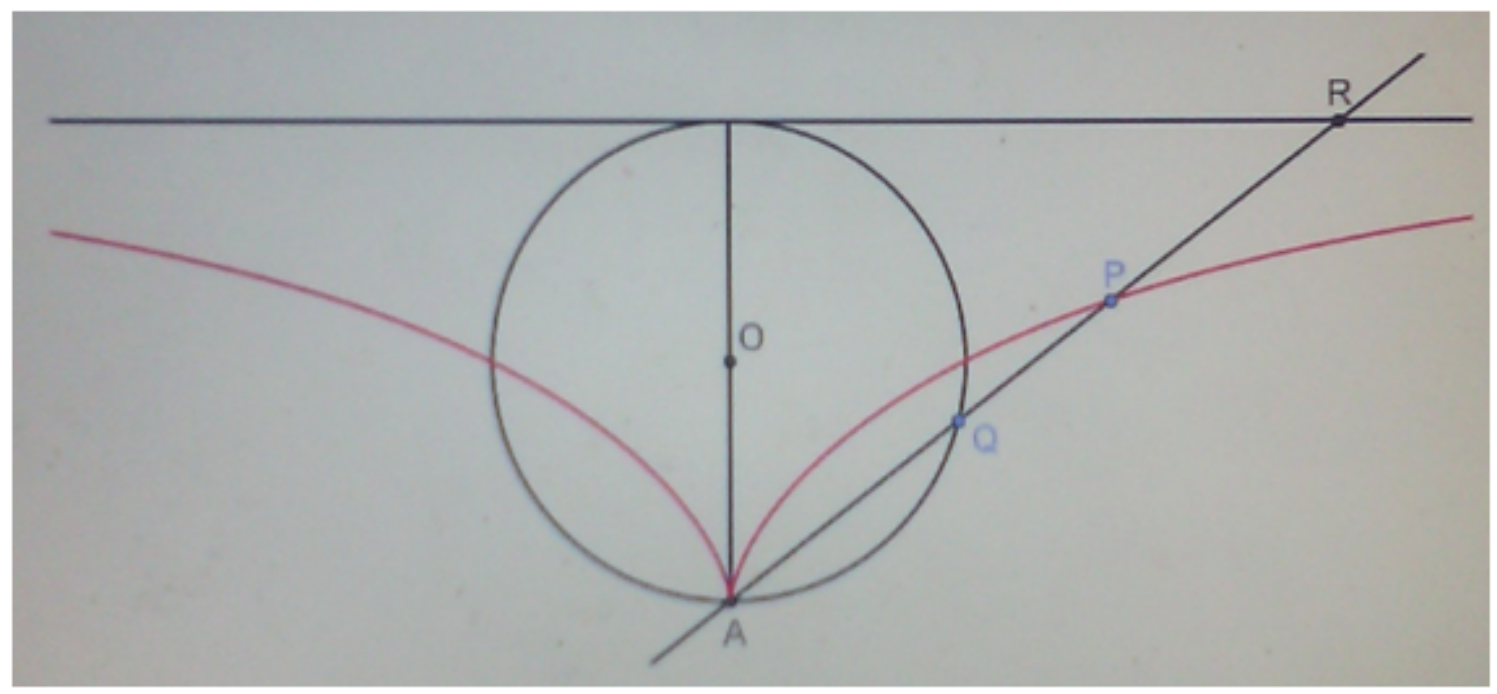

Para encontrar as meias proporcionais, Diocles construiu a cissóide da seguinte maneira: Tracemos uma circunferência de centro $O$, de tal maneira que $\overline{A B}$ e $\overline{C D}$ sejam diâmetros perpendiculares entre si. Marquemos $E$ e $F$ dois pontos da circunferência, de tal maneira que $\overline{E B}=\overline{B F}$. Tracemos dois segmentos perpendiculares a $\overline{C D}$ passando pelos pontos $E$ e $F$, determinando assim em $\overline{C D}$ os pontos $H$ e $G$. Tracemos a reta $\overline{E C}$ que interceptará $\overline{F H}$ em $P$. 
Assim o lugar geométrico do ponto $P$, quando $E$ e $F$ se movimentam nos quadrantes $\widehat{D B}$ e $\widehat{B C}$, respectivamente, sempre com $\overline{E B}=\overline{B F}$, descreve a curva de Diocles para encontrar as meias proporcionais. Conforme figura.

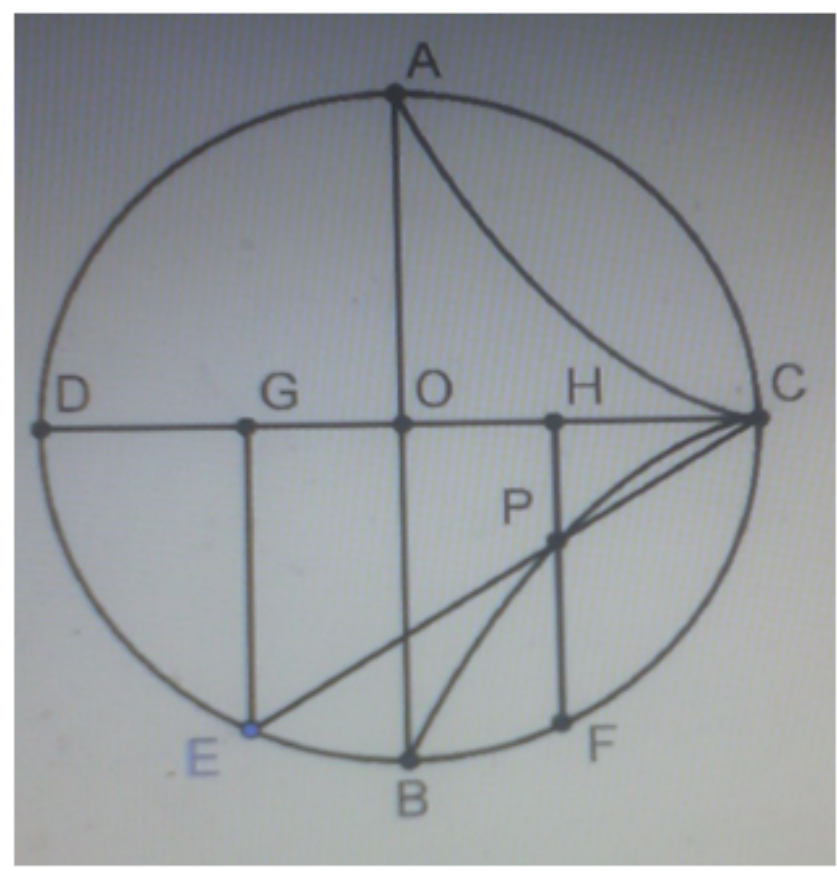

Dessa construção segue que os segmentos $\overline{H F}$ e $\overline{H C}$ são as meias proporcionais entre $\overline{D H}$ e $\overline{H P}$, isto quer dizer que $\frac{\overline{D H}}{\overline{H F}}=\frac{\overline{H F}}{\overline{H C}}=\frac{\overline{H C}}{\overline{H P}}$. Para provar tal resultado comecemos a observar que os triângulos $D H F$ e $H F C$ são semelhantes (Elementos VI, 13), logo teremos que $\frac{\overline{D H}}{\overline{H F}}=\frac{\overline{H F}}{\overline{H C}}$, isto é, $\overline{H F}$ é a meia proporcional entre $\overline{D H}$ e $\overline{H C}$.

Por construção os triângulos $G E C$ e $H F D$ são congruentes, logo, $\frac{\overline{D H}}{\overline{H F}}=\frac{\overline{G C}}{\overline{G E}}$ e como os triângulos GEC e HPC também são semelhantes (Elementos VI, 4), logo, $\frac{\overline{G C}}{\overline{G E}}=\frac{\overline{H C}}{\overline{H P}}$. Portanto, teremos o resultado desejado: $\frac{\overline{D H}}{\overline{H F}}=\frac{\overline{H F}}{\overline{H C}}=\frac{\overline{H C}}{\overline{H P}}$

Assim, se tivermos $\overline{D H}=2 \overline{H P}$, onde $\overline{H P}=a$ é a aresta de um cubo qualquer, então $\overline{H C}$ será a aresta de outro cubo, cujo volume é o dobro do volume do cubo de aresta $a$.

Como podemos observar a cissóide de Diócles é mais um engenho matemático, resultado da heurística presente em Diócles, promovida pela busca de resolver o problema aqui em questão. 


\subsection{Soluções alternativas para a quadratura do círculo}

Como mencionado anteriormente, o problema da quadratura do círculo, consiste em construir apenas com régua não graduada e o compasso um quadrado, cuja área seja igual a área de um círculo dado. Este problema aparece pela primeira vez no papiro de Rhind, escrito por Ahmes, aproximadamente em 1650 a.C. e que era na verdade uma cópia de um documento escrito 200 anos antes. O papiro apresenta uma solução aproximada para o problema ao tomar o lado do quadrado com comprimento igual a $\frac{8}{9}$ do diâmetro do círculo.

Assim, supondo que o raio do círculo que se deseja quadrar meça 1, então sua área será $\pi$. Logo, o lado do quadrado deveria ter $\frac{8}{9}$ de 2 , o que dá aproximadamente 1,77778 e, sendo assim, a área do quadrado será aproximadamente 3,1604, que seria o valor de $\pi$ e, de fato, é uma boa aproximação.

O primeiro matemático da Grécia antiga, de que se tem conhecimento, que apresentou uma solução alternativa para o problema da quadratura foi Anaxágoras (499 - 428 a.C). No entanto, não há registros de tal solução, o que se sabe é que muito provavelmente, ele conseguiu a solução quando estava preso. Conforme [12] "Não conhecemos a construção de Anaxágoras, mas o que se tem é o que escreveu Plutarco que ele se ocupou desse problema quando estava preso." (FERREIRA. 2011, pg. 198)

Os primeiros registros que temos sobre as tentativas de quadrar o círculo advém de Hipócrates de Quios. Ele conseguiu fazer a quadratura de algumas lunas (ou luas), que são figuras em formato de lua, isto é, limitadas por dois arcos de circunferências. Apesar disso, Hipócrates não conseguiu resolver o problema da quadratura do círculo, pelo menos não há registros de nenhuma construção de sua autoria que resolve tal problema.

Ao contrário do problema da duplicação do cubo, existem poucas soluções alternativas para a quadratura do círculo. Veremos a seguir as soluções atribuídas a Hípias e a Arquimedes e os potenciais heurísticos destas soluções.

\subsubsection{A solução de Hípias}

Hípias de Elis foi um matemático do século V a. C. e inventou um instrumento mecânico que serve tanto para resolver o problema da quadratura do círculo quanto o da trissecção de um ângulo qualquer. Por esse motivo a sua invenção é chamada 
às vezes de quadratriz e às vezes de trissectriz.

A sua curva é construída da seguinte maneira: Dado Um quadrado $A B C D$, onde o lado $A D$ gira em movimento circular uniforme em torno de $A$ até que coincida com o lado $A B$ e ao mesmo tempo o lado $D C$ desce com velocidade constante até coincidir também com o lado $A B$. É imprescindível destacar que os dois movimentos devem estar sincronizados de tal forma que ambos os lados $A D$ e $D C$, mesmo tendo velocidades distintas, coincidam exatamente no mesmo instante no lado $A B$. Com isso, a quadratriz de Hípias é o lugar geométrico traçado pelas intersecções dos dois lados móveis $A D$ e $D C$ durante o trajeto descrito anteriormente.

A figura a seguir representa tal construção, onde curva $D P Z$ representa a quadratriz de Hípias.

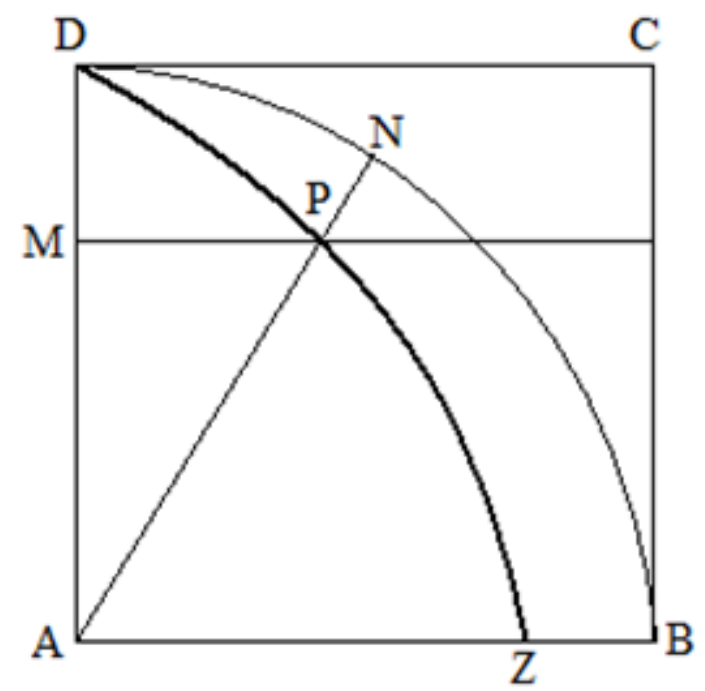

Dessa construção, chamando de $a$ o lado do quadrado $A B C D$, segue que o segmento $\overline{A Z}=\frac{2 a}{\pi}$. De fato, chamemos de $\theta$ o ângulo $P \hat{A} Z$, os segmentos $\overline{A M}=y$ e $\overline{M P}=x$. Assim, pela proporcionalidade dos dois movimentos teremos que $\frac{y}{\theta}=k$, onde $k$ é a constante de proporcionalidade.

Tomando agora o caso particular onde $\theta=\frac{\pi}{2}$ e $y=a$, logo, $\frac{a}{\frac{\pi}{2}}=k$, então, $k=\frac{2 a}{\pi}$. Assim, segue que $\frac{y}{\theta}=\frac{2 a}{\pi}$, então, $\theta .2 a=y \pi$. Logo, $\theta=\frac{y \pi}{2 a}$, isto é, $y=\frac{2 a \theta}{\pi}$.

Por outro lado, tomemos por $\beta$ a distância do vértice $A$ a qualquer ponto da quadratriz. Com isso teremos um triângulo retângulo, onde $\beta$ é a hipotenusa e $y$ é um dos catetos. Logo, teremos que $\sin \theta=\frac{y}{\beta}, \operatorname{assim} \beta=\frac{y}{\sin \theta}$ e como $y=\frac{2 a \theta}{\pi}, \operatorname{logo}$, $\beta=\frac{\frac{2 a \theta}{\pi}}{\sin \theta}=\frac{2 a \theta}{\pi \sin \theta}$.

Agora, aplicando o limite em $\theta$ indo para zero, segue que,

$$
\lim _{\theta \rightarrow 0} \beta=\lim _{\theta \rightarrow 0} \frac{2 a \theta}{\pi \sin \theta}=\frac{2 a}{\pi} \lim _{\theta \rightarrow 0} \frac{\theta}{\sin \theta}=\frac{2 a}{\pi} .
$$


Assim, $\overline{A Z}=\beta=\frac{2 a}{\pi}$.

Dessa forma, construímos um segmento de comprimento igual a $\frac{2 a}{\pi}$ e, seguindo [10], é fácil dividir usando apenas régua e compasso, o segmento $\frac{2 a}{\pi}$ por $2 a$, obtendo assim, o segmento $\frac{1}{\pi}$. Em seguida, se constrói o inverso de $\frac{1}{\pi}$, conforme descreve [9],

O inverso se obtém levantando-se uma perpendicular sobre um extremo do segmento $\frac{1}{\pi}$ fazendo-a coincidir com o arco de raio unitário de centro no outro extremo deste mesmo segmento. Construindo-se um angulo reto entre o segmento que une o centro do arco e o ponto obtido anteriormente, determina-se então um triângulo retângulo de hipotenusa igual a $\pi$, conforme figura. (D‘ACAMPORA, 2014, pg. 21)

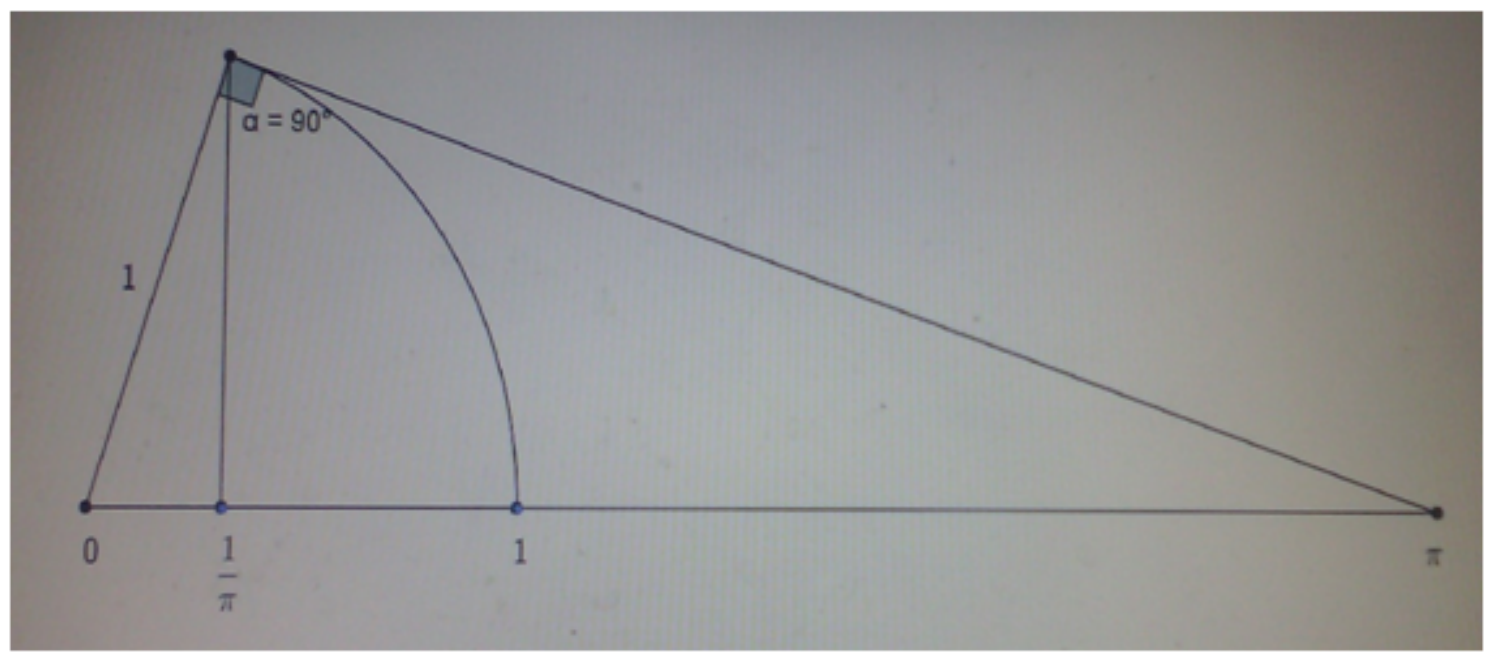

Com isso, obtemos um segmento de comprimento igual a $\pi$, resolvendo assim o problema da quadratura do círculo, já que a área de um circulo é dada por $\pi r^{2}$, então o lado do quadrado deve ser $\sqrt{\pi r^{2}}$ e tendo um segmento de comprimento igual a $\pi$, fica fácil construir $\sqrt{\pi r^{2}}$. Mais detalhes dessa construção pode ser encontrada em d'Acampora (2014, pg. 14).

Esta solução de Hípias nos mostra seu poder inventivo para a busca de soluções para os problemas clássicos da matemática grega. Engenho bastante sofisticado capaz de promover uma solução alternativa para a quadratura do círculo. Assim, esta curva é mais um exemplo da heurística promovida pela não solução destes problemas clássicos apenas com o uso da régua não graduada e o compasso.

\subsubsection{A solução de Arquimedes}

O famoso Arquimedes (287 - 212 a. C.) também contribuiu com a busca de soluções para os três problemas clássicos da matemática grega. Sua principal 
3. Identificando a Heurística como a ciência da procura e invenção: soluções alternativas para os três problemas clássicos da matemática grega

contribuição nesse sentido foi a espiral que serve para resolver os problemas da quadratura e da trissecção.

A sua curva mecânica é definida como sendo o lugar geométrico de um ponto que se move com velocidade constante sobre uma reta que também se movimenta numa velocidade angular constante em torno de um ponto de origem fixa, digamos O. Conforme figura a seguir:

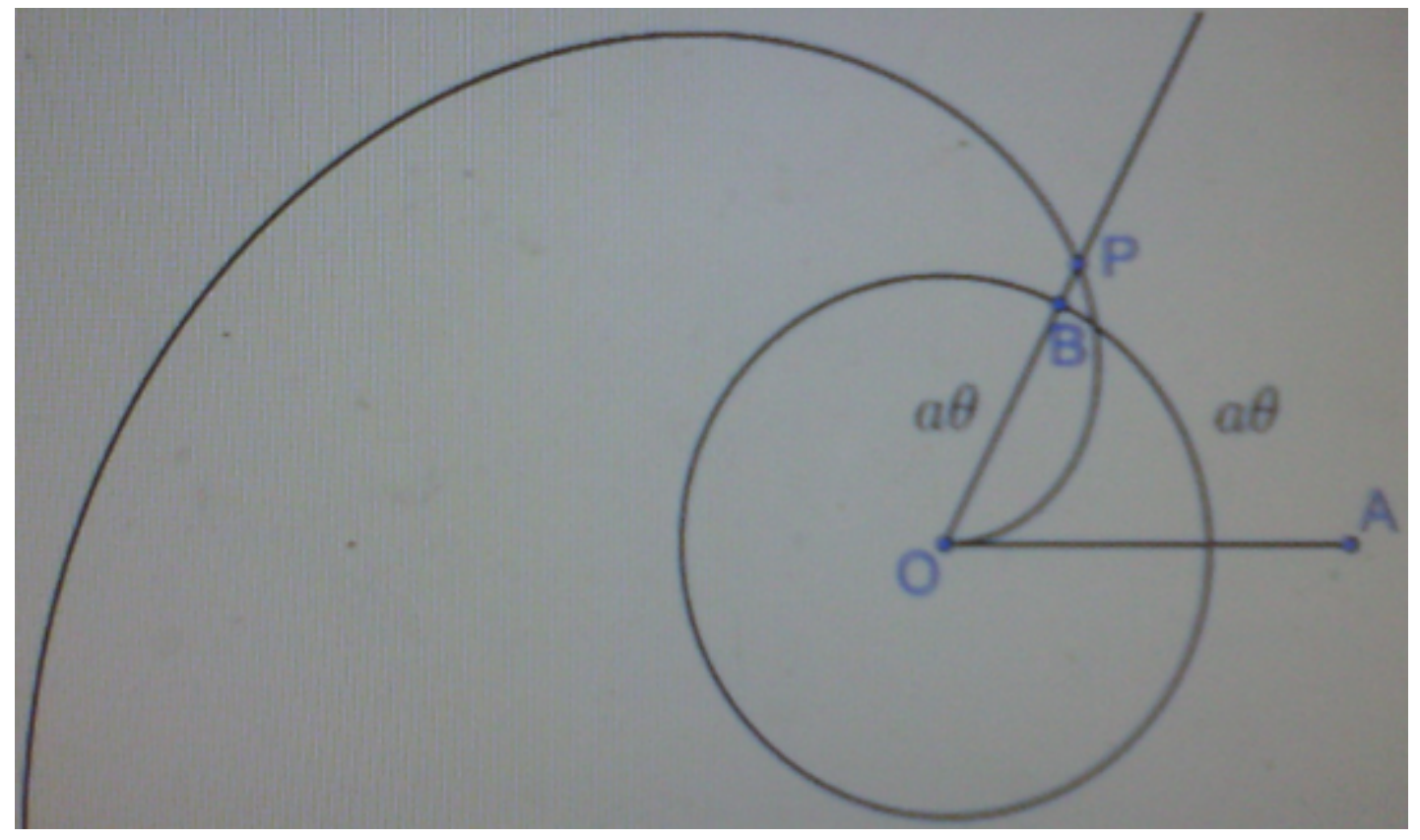

Assim, tomando o sistema polar de referência, a posição OA do eixo de rotação quando $P$ coincide com a origem $O$ do raio, teremos que $O P$ é proporcional ao ângulo $P \hat{O} A$, e assim a equação polar da espiral será dada por $r=a \theta$, onde $a$ é a constante de proporcionalidade.

Para utilizar essa curva para fazer a quadratura, tracemos um círculo de centro $O$, que é o ponto fixo, e raio $r$. $P$ é o ponto da espiral que completou uma volta e nele tracemos sua reta tangente que corta a reta perpendicular a $\overline{O P}$ e que passa por $O$, em um ponto que designaremos por $T$, conforme a seguinte figura: 


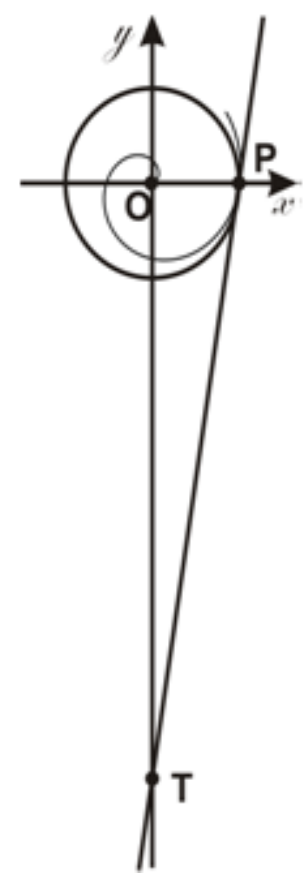

Assim, Arquimedes mostrou que o segmento $\overline{O T}$ é igual ao comprimento da circunferência do circulo de centro $O$ e raio $\overline{O P}=r$. Esse fato foi crucial para resolver a quadratura do círculo, pois Arquimedes já tinha provado que a área de um círculo é igual a área de um triangulo retângulo onde o cateto menor é igual ao raio deste círculo e o cateto maior é igual ao comprimento deste círculo. Assim, da figura anterior, teremos que a área do circulo de centro $O$ e raio $\overline{O P}$ é igual a área do triângulo $O P T$.

Agora, como temos um triângulo cuja área é igual a de um círculo, então o próximo passo é construir um quadrado com área igual a de um triângulo dado. Como, no caso da figura anterior, temos que a área do triângulo $O P T$ é dado por $\frac{1}{2} \overline{O T} \cdot \overline{O P}$, assim, a área do quadrado também deverá ser $\frac{1}{2} \overline{O T} \cdot \overline{O P}$, isto é, o lado do quadrado deve medir $\sqrt{\frac{\overline{O T} \cdot \overline{O P}}{2}}$, o que é fácil construir com régua e compasso.

Para demonstrar que $\overline{O T}$ é igual ao comprimento da circunferência do círculo de centro $O$ e raio $\overline{O P}$ basta tomar um ponto de coordenadas $(x, y)$, cujo eixo $x$ é a reta $\overline{O P}$ e $y$ é a reta ortogonal que tem como expressões em parâmetros polares $\theta$, que é o ângulo de rotação e $r$ o raio: $x=\frac{r \theta}{2 \pi} \cos \theta$ e $y=\frac{r \theta}{2 \pi} \sin \theta$.

Assim, as derivadas em relação a $\theta$, são:

$$
\frac{d x}{d \theta}=\frac{r}{2 \pi}(-\theta \sin \theta+\cos \theta) ; \frac{d y}{d \theta}=\frac{r}{2 \pi}(\theta \cos \theta+\sin \theta)
$$


Com isso, teremos que a inclinação da reta tangente será:

$$
\frac{d y}{d x}=\frac{\frac{r}{2 \pi}(\theta \cos \theta+\sin \theta)}{\frac{r}{2 \pi}(-\theta \sin \theta+\cos \theta)}
$$

Agora, aplicando a equação no ponto $\theta=2 \pi$, segue que $\frac{d y}{d x}=2 \pi$. Com isso, a equação da reta tangente nesse ponto será $y=2 \pi(x-r)$. Assim, para o ponto $T=(0,-2 \pi r)$, o comprimento do segmento $\overline{O T}=2 \pi r$.

Dessa forma, teremos que a área do triângulo $O P T$ é igual a $\frac{1}{2} \overline{O T} \cdot \overline{O P}$ que é igual a $\frac{1}{2} 2 \pi r \cdot r=\pi r^{2}$, que por sua vez é igual a área o círculo de raio $r$.

Esta solução de Arquimedes é bastante engenhosa, ele primeiro constrói um triângulo retângulo com área igual a de um círculo e em seguida constrói um quadrado com área igual a área desse triângulo. Assim, a espiral de Arquimedes é mais um exemplo da heurística trazida pela busca de solucionar o problema da quadratura do círculo, visto que, muito possivelmente, tal curva mecânica não teria sido inventada se houvesse uma solução com uso apenas da régua não graduada e compasso para os três problemas clássicos da matemática.

\subsection{Soluções alternativas para a trissecção de um ângulo qualquer}

Como já relatado, o problema da trissecção de um ângulo consiste em dividir apenas com régua não graduada e compasso, um ângulo qualquer em três partes iguais. Este problema foi bastante significativo para o desenvolvimento da matemática, visto que possibilitou o estudo de novas técnicas de construções geométricas e o estudo de novas curvas. Conforme Sousa (2001, pg. 15) "As tentativas para resolver o problema da trissecção do ângulo foram muito frutíferas ao contribuírem para o desenvolvimento da geometria."

Em certos aspectos este problema é mais especial que os outros dois, um destes aspectos é o fato de podermos trissectar, apenas com os instrumentos euclidianos, alguns ângulos especiais, como é o caso do ângulo de $90^{\circ}$.

Para trissectar o ângulo reto, digamos $C \hat{A} B=90^{\circ}$, usando apenas régua não graduada e compasso, basta traçar um círculo de centro em $A$ e raio $r$ qualquer que irá cortar o lado $A B$ do ângulo em um ponto que designaremos por $E$. Em seguida, tracemos outro círculo de mesmo raio $r$ e com centro em $E$ que interceptará o primeiro círculo em dois pontos, para este caso, marquemos apenas o ponto superior, 
que chamaremos de $D$. Assim o triângulo $A D E$ é equilátero, já que por construção cada um de seus lados mede $r$, logo o ângulo $D \hat{A} E=60^{\circ}$ e consequentemente o ângulo $C \hat{A} D=30^{\circ}$, ou seja, é a terça parte do ângulo $C \hat{A} B=90^{\circ}$. Conforme figura:

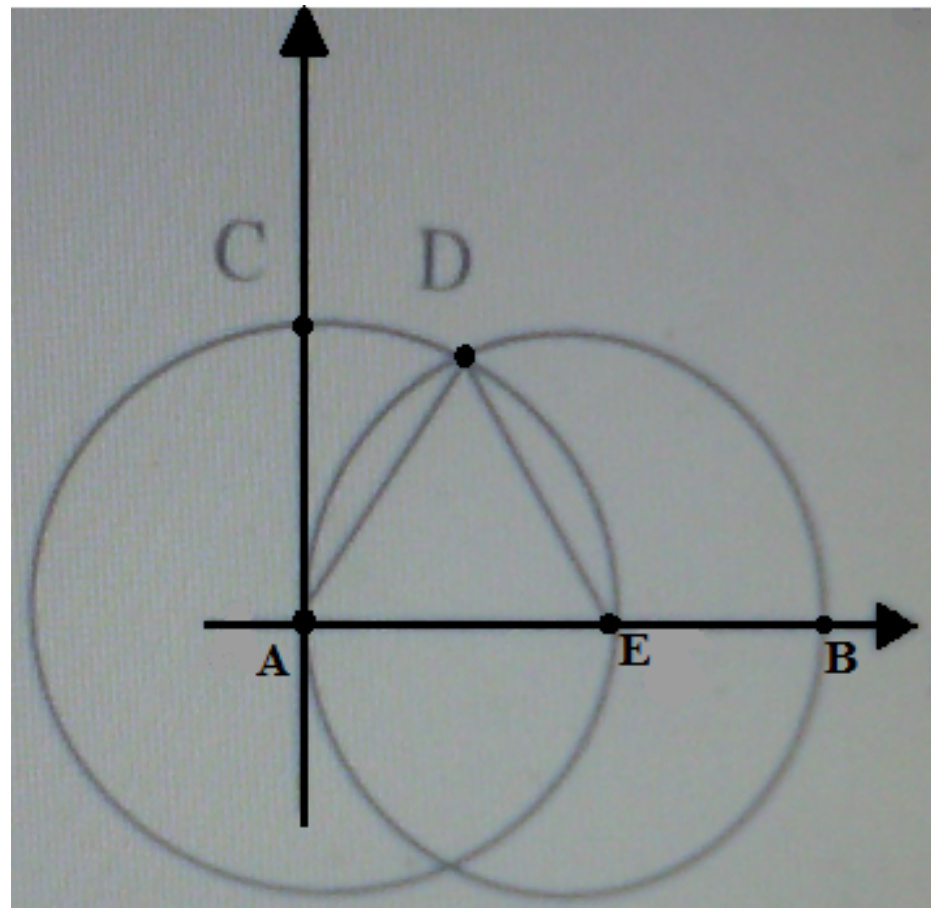

Essa trissecção do ângulo reto foi demonstrada por Pappus no seu livro IV da coleção matemática. No entanto, o problema de fato aparece quando desejamos trissectar um ângulo qualquer, aí temos que recorrer a outras construções que carecem do uso de ferramentas mais sofisticadas, como veremos a seguir.

\subsubsection{A redução do problema da trissecção a construção por nêusis}

Tal como a duplicação do cubo, o problema da trissecção de um ângulo qualquer também foi reduzido a outro problema mais simples, que foi a construção por nêusis, palavra de origem grega neuein cujo significado é apontar ou inclinar. Este tipo de construção consiste em inserir entre duas curvas um segmento de reta com comprimento predefinido de maneira que este segmento ou o seu prolongamento passe por um ponto fixo.

Estas construções são aplicáveis a ângulos agudos, visto que os ângulos retos podem ser trissectados apenas com régua não graduada e compasso, como visto anteriormente, e caso o ângulo seja obtuso basta transformá-lo em somas de ângulos 
retos com ângulos agudos. Por isso, trissectar um ângulo agudo é suficiente para resolver a trissecção de um ângulo qualquer.

Para entendermos melhor esta redução do problema tracemos um ângulo agudo, digamos $A \hat{B} C$, com $\overline{A B}$ e $\overline{B C}$ os lados deste ângulo. Assim, pelo ponto $A$ tracemos uma reta paralela e uma reta perpendicular ao lado $\overline{B C}$ e inserimos um segmento de comprimento duplo ao segmento $\overline{A B}$, digamos $\overline{D E}=2 \overline{A B}$, entre estas duas retas, de modo que o vértice do ângulo, isto é, o ponto $B$, esteja na mesma reta que os pontos $D$ e $E$. Conforme imagem a seguir:

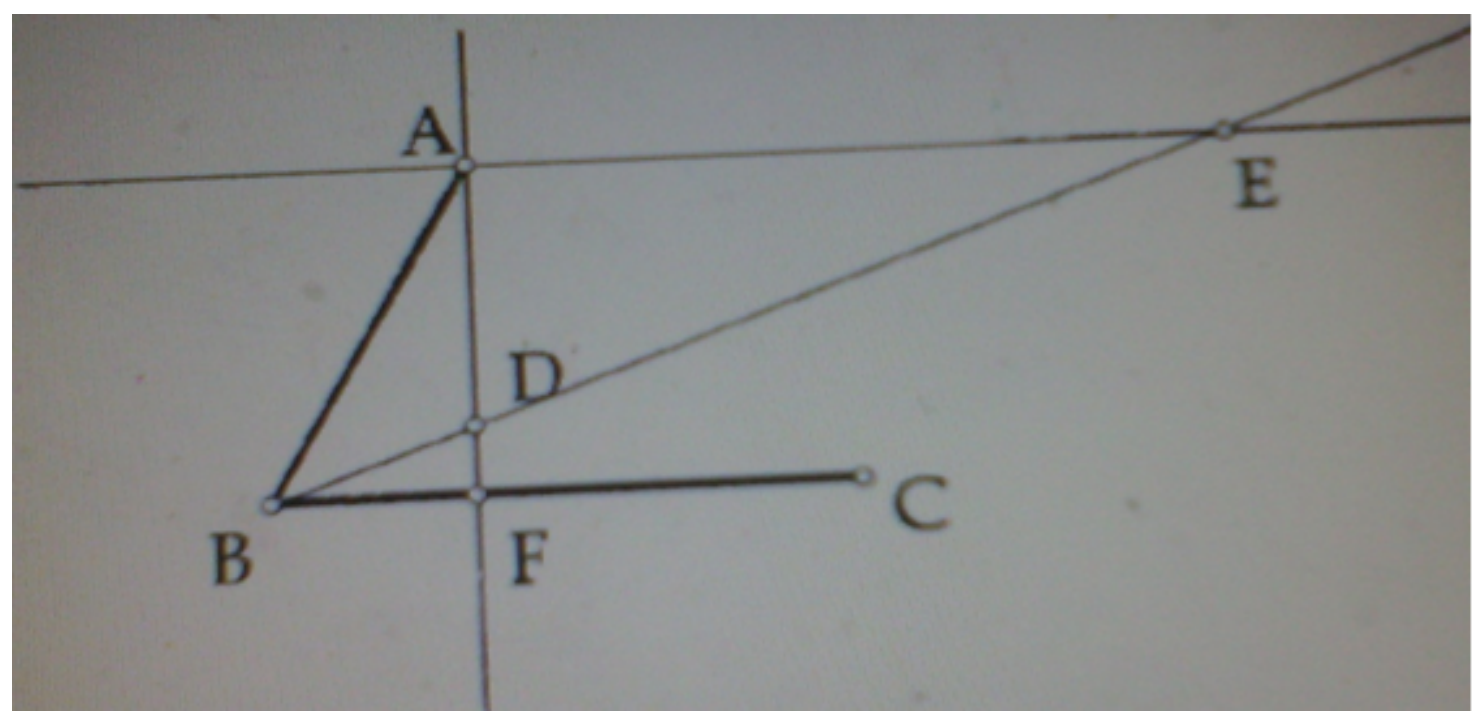

Com isso, temos que o ângulo $D \hat{B} F$ é igual a um terço do ângulo $E \hat{B} C$. Para provar isto, marquemos primeiro $H$ como sendo o ponto médio do segmento $\overline{D E}$, e como $\overline{D E}=2 \overline{A B}$, então, $\overline{D H}=\overline{A B}=\overline{H E}$. Por construção, a reta que passa por $A$ e $E$ é paralela a reta que passa por $B$ e $C$, consequentemente, os ângulos $A \hat{E} H$ e $H \hat{B} C$ são iguais, além disso, como temos que o ângulo $E \hat{A} D=90^{\circ}$, então o triângulo $A D E$ pode ser inscrito numa circunferência com centro no ponto $H$, conforme a seguinte figura: 
3. Identificando a Heurística como a ciência da procura e invenção: soluções alternativas para os três problemas clássicos da matemática grega

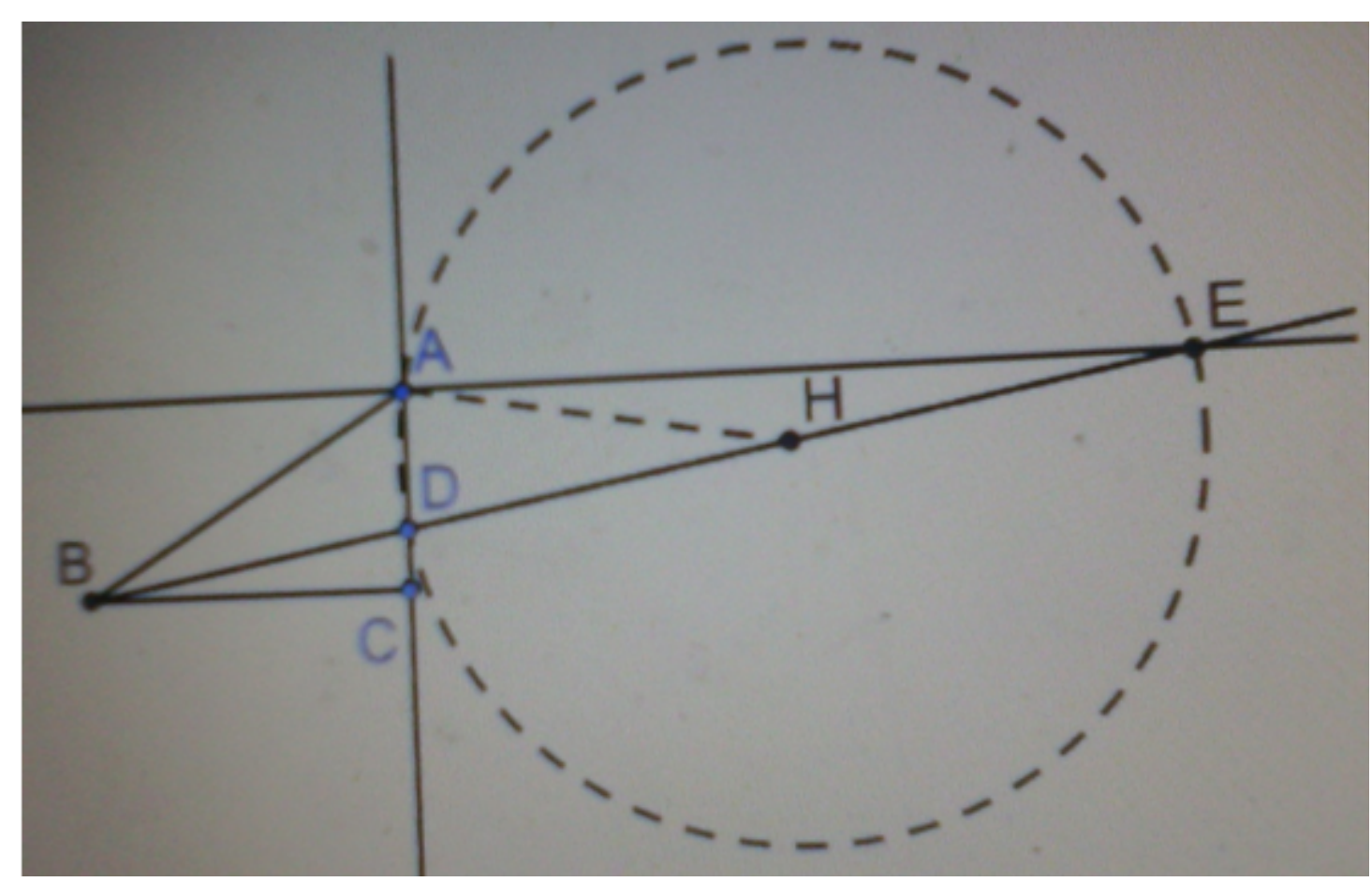

Temos também, por construção, $\overline{H A}=\overline{H E}=\overline{H D}=\overline{A B}$, assim, os triângulos $A H E$ e $A B H$ são isósceles e por isso os ângulos $E \hat{A} H=A \hat{E} H$ e $A \hat{H} B=A \hat{B} H$. Observe também que o ângulo $A \hat{H} B$ é um ângulo externo ao triângulo $A H E$, logo, o ângulo $A \hat{H} B=E \hat{A} H+A \hat{E} H=2 A \hat{E} H$ e como os ângulos $A \hat{E} H$ e $H \hat{B} C$ também são iguais, assim, $2 A \hat{E} H=2 H \hat{B} C$. Sendo assim, como o ângulo inicial $A \hat{B} C=A \hat{B} H+H \hat{B} C=A \hat{H} B+H \hat{B} C=2 H \hat{B} C+H \hat{B} C=3 H \hat{B} C$, isto é, o ângulo $H \hat{B} C$ é um terço do ângulo $A \hat{B} C$.

Dessa forma, temos que o problema da trissecção de um ângulo agudo qualquer está resolvido, basta saber inserir o segmento de reta $\overline{D E}$ com comprimento duplicado de $\overline{A B}$, entre $\overline{A C}$ e $\overline{A E}$ e intercepte o ponto $B$. Fazer esse tipo de construção se chama construção por nêusis.

Esta redução do problema de trissectar um ângulo agudo a um problema de construção por nêusis foi de extrema importância para a matemática. Para Sousa:

A redução do problema da trissecção do ângulo a um problema de inclinação, isto é, a um problema de nêusis, deve ter sido de extrema importância para os geômetras gregos. De fato, embora não seja possível encontrar uma solução com régua não graduada e compasso, é extremamente fácil de executar a construção com outros instrumentos mecânicos, como por exemplo uma régua graduada onde se marca a medida pretendida. Assim, estava encontrado um novo caminho de investigação, embora não o único, pois como veremos é possível encontrar soluções sem recorrer a construções por nêusis. (SOUSA, 2001, pg. 19)

Podemos dizer que esta redução foi o primeiro fruto da heurística concebido pela 
busca de resolver a trissecção do ângulo, o que foi algo bastante importante para a geometria grega, pois quase todas as outras soluções encontradas se baseavam em construções por nêusis, como veremos a seguir.

\subsubsection{A solução de Nicomedes}

Como já apresentado em (3.1.5), a curva inventada por Nicomedes, conhecida como conchóide, também serve para resolver o problema da trissecção de um ângulo agudo. Esta curva revolve a trissecção pelo método de construção por nêusis como vimos anteriormente.

Vamos agora utilizar a conchóide para resolver o problema de construção por nêusis. Para tanto, com base em [43], tomemos um ângulo agudo $A \hat{O} B$, tracemos uma reta (que é a reta $r$, como denominada na definição de conchóide) que passa pelo ponto $A$ e é perpendicular a ao lado $O A$ do ângulo e que corta o lado $\overline{O B} \mathrm{em}$ um ponto $N$. Após, tomemos $K$ como sendo o comprimento do segmento $\overline{O N}$ e traçasse a conchóide com relação a reta $r$, pólo $O$ e a constante de comprimento $2 K$. Por fim, traçasse um reta paralela a $\overline{A O}$ que passa por $N$ e intercepta a curva conchóide em $C$. Conforme figura a seguir:

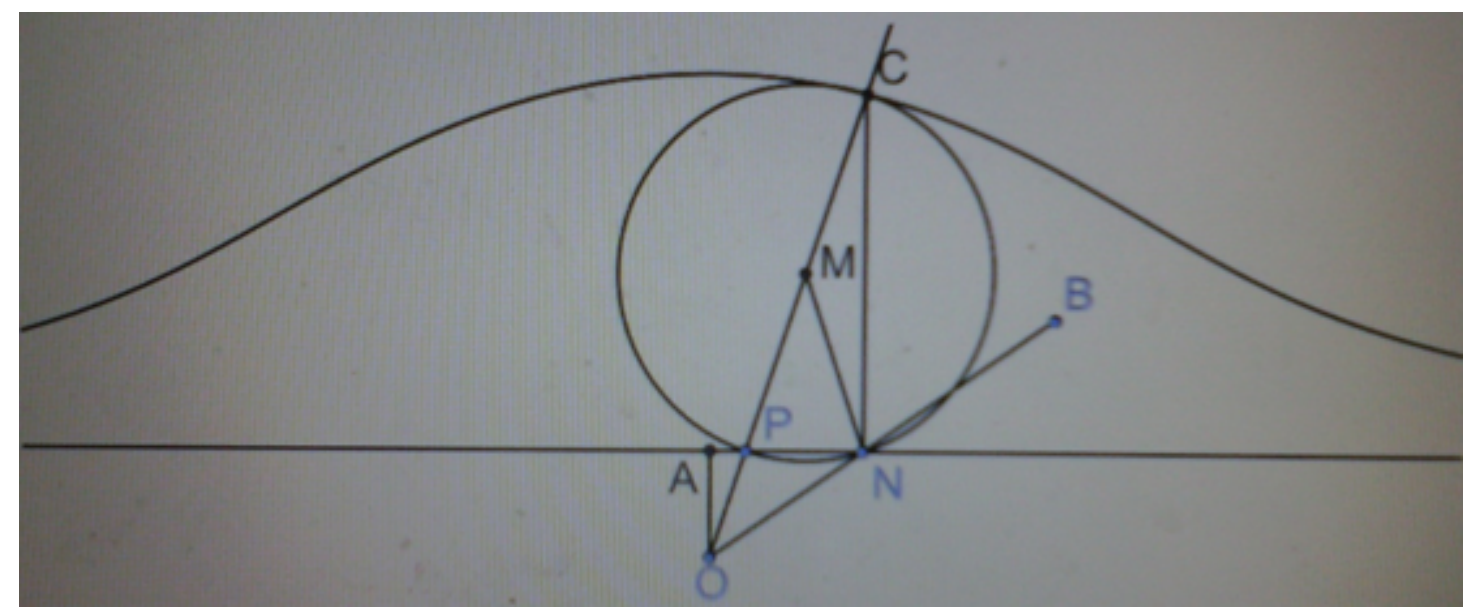

Assim, temos que o ângulo $A \hat{O} C$ é igual a terça parte do ângulo $A \hat{O} B$. Para provar esse resultado chamemos de s a reta paralela a $\overline{A O}$ e que passa por $N$, consequentemente os ângulos $O \hat{C} N$ e $A \hat{O} C$ são iguais. Além disso, chamemos de $P$ a intersecção da reta $r$ com o segmento $\overline{O C}$ e $M$ é o ponto de médio de $\overline{P C}$, isto é, $\overline{M C}=\overline{P M}=X$.

Devido a construção, $P \hat{N} C$ é um ângulo reto, por isso, o triângulo $P N C$ pode ser inscrito em uma circunferência de centro em $M$ e raio $X$. Também por construção o parâmetro $K$ para a conchóide é igual a $2 \overline{O N}$. Com isso, segue que o triângulo 
$M N C$ é isósceles, logo os ângulos $M \hat{C} N$ e $M \hat{N} C$ são iguais e o triângulo $O M N$ também é isósceles, assim, os ângulos $N \hat{M} O$ e $M \hat{O} N$ são congruentes.

Ainda temos que $N \hat{M} O$ é um ângulo externo do triângulo $M C N, \operatorname{logo}, N \hat{M} O$ é igual a soma dos ângulos $M \hat{N} C$ e $M \hat{C} N$, isto é, $N \hat{M} O=M \hat{N} C+M \hat{C} N$. Logo, $N \hat{M} O=M \hat{N} C+M \hat{C} N=2 M \hat{C} N$.

Como o ângulo $M \hat{C} N=O \hat{C} N$ e $N \hat{M} O=M \hat{O} N=M \hat{O} B$, então, segue que o ângulo $M \hat{O} B=N \hat{M} O=2 M \hat{C} N=2 O \hat{C} N=2 A \hat{O} C$. Mas como o ângulo $A \hat{O} B=A \hat{O} C+M \hat{O} B$, então, $A \hat{O} B=A \hat{O} C+2 A \hat{O} C=3 A \hat{O} C$, isto é, o ângulo $A \hat{O} C=\frac{A \hat{O} B}{3}$.

Assim, temos uma solução de construção por nêusis que resolve o problema da trissecção de um ângulo agudo. Com isso, podemos afirmar que essa curva mecânica é mais um exemplo das invenções matemáticas trazidas pelos três problemas clássicos, o que nos mostra mais uma vez a heurística por traz da não solução desses problemas geométricos.

\subsubsection{A solução de Hípias}

A solução de Hípias não consiste em construção por nêusis. Detalhes sobre a construção da trissectriz pode ser encontrada em 3.2.1. Nos remeteremos agora a demonstrar como esta curva serve para resolver a trissecção de um ângulo qualquer.

Para tanto vamos considerar um ângulo agudo $X \hat{A} B$, pelo qual tracemos um quadrado $A B C D$ cujo lado coincida com o lado $\overline{A B}$ do ângulo $X \hat{A} B$. Construímos em seguida a curva de Hípias e designaremos por $Z$ o ponto de intersecção do lado $A X$ do ângulo a trissectar com a curva. Por $Z$ tracemos uma reta paralela ao lado $\overline{A B}$ do quadrado e $P$ é o ponto de intersecção desta reta paralela com o lado $\overline{A D}$ do quadrado. Em seguida, dividimos o segmento $\overline{A P}$ em três partes iguais, o que é possível usando apenas régua não graduada e compasso, sendo assim, determinaremos o segmento $\overline{A P 1}$ que é a terça parte de $\overline{A P}$. Por fim, pelo ponto $P 1$ tracemos outra reta paralela ao lado $\overline{A B}$ do quadrado $A B C D$ que interceptará a trissectriz de Hípias no ponto $L$. Essa construção pode ser observada na imagem a seguir. 
3. Identificando a Heurística como a ciência da procura e invenção: soluções alternativas para os três problemas clássicos da matemática grega

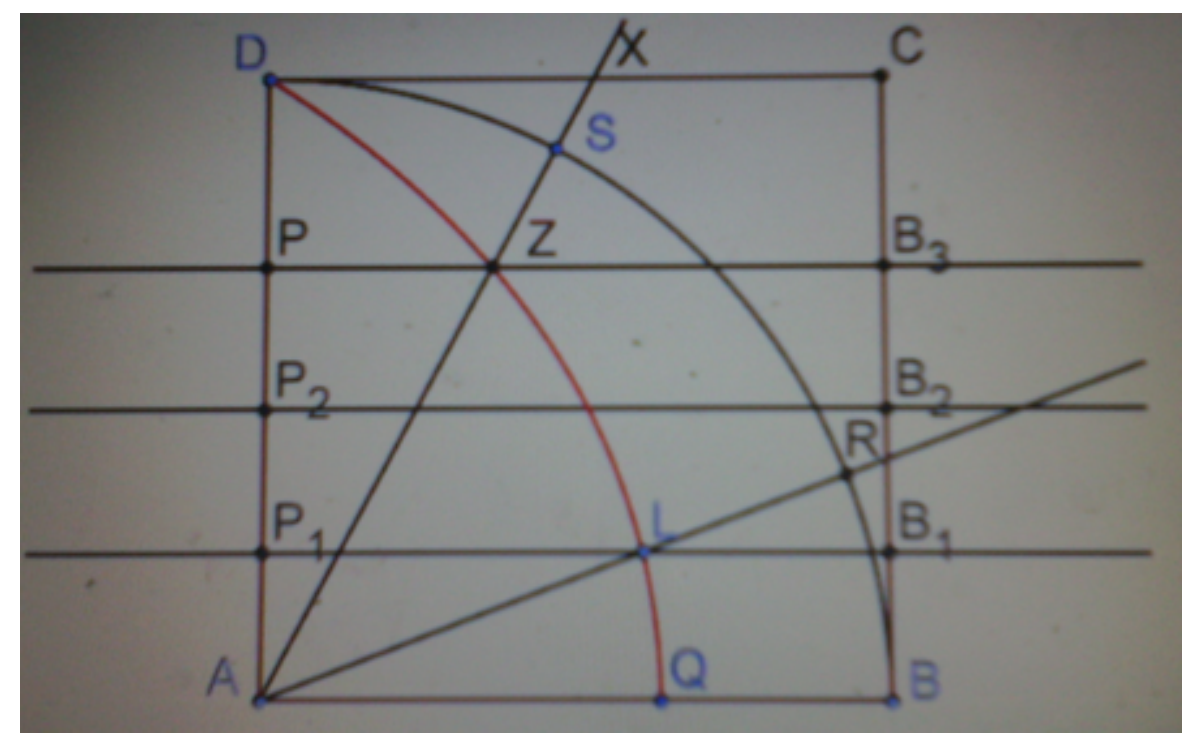

Com isso, teremos que o ângulo $L \hat{A} B$ é a terça parte do ângulo $X \hat{A} B$. Para provar esse resultado acompanhemos na figura anterior os seguintes pontos: $S$ e $R$ são os pontos de intersecção do arco $\widehat{D B}$ com as retas $A Z$ e $A L$, respectivamente; $B 3$ e $B 1$ são os pontos de intersecção do lado $\overline{B C}$ do quadrado com as retas $P Z$ e $P 1 L$, respectivamente.

Observemos agora que as retas $P 1 B 1$ e $A R$ interceptam-se no ponto $L$ da curva trissectriz e do mesmo modo as retas $P B 3$ e $A X$ também se interceptam em outro ponto $Z$ desta mesma curva. Por isso, pela proporcionalidade dos movimentos que traçam a curva de Hípias (propriedades da curva), temos a seguinte relação:

$$
\frac{A P}{A P 1}=\frac{\operatorname{arco} \widehat{S B}}{\operatorname{arco} \widehat{R B}}
$$

Como temos também que a amplitude de um ângulo ao centro é igual a amplitude do arco compreendido entre seus lados, então segue que:

$$
\frac{\operatorname{arco} \widehat{S B}}{\operatorname{arco} \widehat{R B}}=\frac{Z \hat{A} B}{L \hat{A} B}
$$

Assim, como $\overline{A P}=\frac{\overline{A P 1}}{3}$, então teremos que:

$$
\frac{\overline{A P}}{\overline{A P 1}}=\frac{Z \hat{A} B}{L \hat{A} B}
$$

Logo,

$$
\frac{\frac{\overline{A P 1}}{3}}{\overline{A P 1}}=\frac{Z \hat{A} B}{L \hat{A} B}
$$

Portanto, $\frac{1}{3}=\frac{Z \hat{A} B}{L \hat{A} B}$, isto é, $L \hat{A} B=3 Z \hat{A} B$. 
Por isso, temos uma solução alternativa para a trissecção de um ângulo qualquer, já que um ângulo reto pode ser trissectado apenas com os instrumentos euclidianos e os ângulos obtusos podem ser colocados como a soma de ângulos retos mais um agudo.

Para Carvalho (2008, pg. 20) "Esta é a solução mais antiga que conhecemos para o problema da trisecção do ângulo." Na perspectiva de Pappus a trissectriz é uma das mais antigas curvas de que se tem conhecimento e, muito provavelmente, ela foi a primeira curva a ser inventada depois da reta e da circunferência, tendo surgido pelas tentativas de trissectar um ângulo qualquer o que vem a nos mostrar uma vez mais o potencial criativo de novas curvas mecânicas e, consequentemente, novos campos de estudos da matemática na Grécia antiga, caracterizando assim mais um vestígio heurístico dos três problemas matemáticos clássicos.

\subsubsection{As soluções atribuídas a Arquimedes}

Existem pelo menos duas soluções para a trissecção de um ângulo que são atribuídas a Arquimedes. Uma dessas soluções é a trissecção por nêusis e a outra solução consiste em utilizar a espiral.

Para a construção por nêusis, começamos a considerar um ângulo agudo $A \hat{B} C \mathrm{e}$ construímos uma circunferência, com centro em $B$ e raio $r$ de comprimento qualquer, que interceptará os lados do ângulo nos pontos $A$ e $C$. Em seguida, inserimos um segmento de reta $\overline{F D}$ de comprimento igual ao raio $r$ entre a reta $C B$ e a circunferência de maneira que o ponto $A$ fique sobre o prolongamento de $\overline{F D}$. Por fim, tracemos uma reta que passa por $B$ e que é paralela a reta $F A$, que interceptará a circunferência no ponto $G$, conforme ilustração seguinte: 


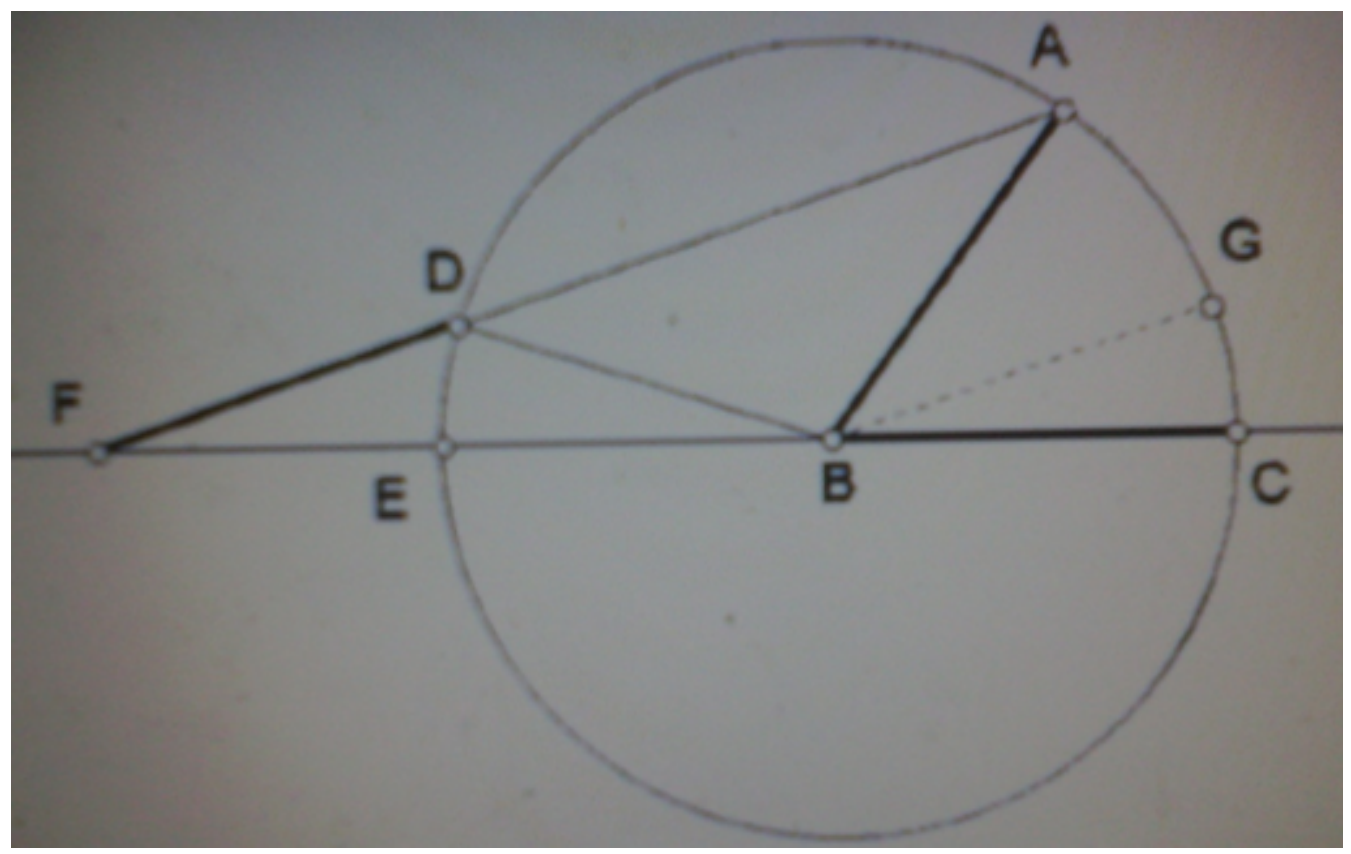

Com isso, temos que o ângulo $G \hat{B} C$ é um terço do ângulo $A \hat{B} C$. Para provar, observe que como as retas $B G$ e $F A$ são paralelas, então temos que os ângulos $G \hat{B} C$ e $D \hat{F} B$ são congruentes e os ângulos $B \hat{A} F$ e $A \hat{B} G$ também são côngruos.

Além disso, como por construção $\overline{D B}=\overline{F D}=\overline{A B}=\overline{B C}$ e assim os triângulos $F D B$ e $D A B$ são isósceles, portanto, os ângulos $D \hat{F} B=D \hat{B} F$ e $B \hat{D} A=D \hat{A} B$. Agora como o ângulo $B \hat{D} A$ é um ângulo externo do triângulo $F D B$, então vale a seguinte igualdade de ângulos $B \hat{D} A=D \hat{F} B+D \hat{B} F$. Por outro lado, como $D \hat{F} B=D \hat{B} F$, então, $D \hat{A} B=B \hat{D} A=D \hat{F} B+D \hat{F} B=2 D \hat{F} B$. Como temos também que o ângulo $G \hat{B} C=D \hat{F} B$, então $D \hat{A} B=2 G \hat{B} C$ e como o ângulo $D \hat{A} B=B \hat{A} F$ e $B \hat{A} F=A \hat{B} G$, então, o ângulo $D \hat{A} B=A \hat{B} G$, consequentemente, o ângulo $A \hat{B} G=2 G \hat{B} C$, isto é, o ângulo $G \hat{B} C$ é um terço do ângulo $A \hat{B} C$, pois, o ângulo $A \hat{B} C=A \hat{B} G+G \hat{B} C$.

A segunda solução de Arquimedes é dada pela sua espiral, curva apresentada na seção 3.2.2. Esta solução será demonstrada em 4.2

As duas soluções nos mostram que de fato Arquimedes se ocupou em resolver os problemas aqui referidos, mesmo não tendo ele dado uma solução direta. Suas estratégias de resolução mostram seu poder inventivo diante dos três problemas clássicos da matemática, problemas estes que podem ter o inspirado a investigar e envolver a matemática com a mecânica, algo totalmente inédito e que lhe rendeu grandes frutos, principalmente na matemática e na física. Mostrando assim que a heurística, como sendo a ciência da procura e invenção, esteve constantemente presente nas pesquisas de Arquimedes, em especial, nas suas pesquisas para resolver os três referidos problemas de construção geométrica. 
3. Identificando a Heurística como a ciência da procura e invenção: soluções alternativas para os três problemas clássicos da matemática grega

As soluções alternativas para os três problemas não se limitam as que foram apresentadas nesse capítulo, no entanto, fizemos uma síntese geral das principais soluções existentes, com o intuito de mostrar as engenhosas construções desenvolvidas por antigos estudiosos da matemática, o que veio a conformar, em certa medida, as linhas de pesquisa na matemática, em especial na geometria, ao longo do tempo. Essas invenções pôdem nos mostrar o potencial destes três problemas clássicos da matemática, como sendo uma amostra da capacidade heurística de muitos matemáticos mediante problemas desafiadores. 


\section{CAPÍTULO 4}

\section{IMPLICAÇÕES EDUCACIONAIS DOS TRÊS PROBLEMAS CLÁSSICOS DA MATEMÁTICA GREGA PARA O ENSINO}

Como pudemos analisar no decorrer dos capítulos precedentes, a heurística é uma importante ciência capaz de promover inventos significativos em determinada área do conhecimento. Assim, ela deve ser incentivada na cultura de educação cientifica para que a aprendizagem se torne, de fato, mais qualificada e o ensino mais dinamizado.

O ensino atual, que ainda é centralizado no educador, é dado, a meu ver equivocadamente, através de transmissão de conceitos e definições perfeitas e acabadas, o que pode causar no aprendiz a falsa idéia de que o conhecimento sempre esteve pronto e que foi concebido milagrosamente. Para Lakatos (1978, pg. 186) "A Matemática é apresentada como uma série sempre crescente de verdades imutáveis e eternas, o estilo dedutivista oculta a luta, esconde a aventura. Toda a história evapora, as sucessivas formulações provisórias dos teoremas durante a prova são relegadas ao esquecimento enquanto o resultado final é exaltado como infabilidade sagrada." Esse modelo de ensino, em grande medida, poda a mente criativa dos estudantes que, frente a essa situação, limita-se a absorver os conceitos e definições.

Com isso, se o sistema educacional se comportar desta maneira, pode tornar a 
educação científica frágil, pois, ao limitar a criatividade dos estudantes, poderemos estar perdendo novas invenções que podem ser úteis para o progresso de determinada ciência, no nosso caso da matemática.

Tudo isso que me referi é para mostrar que uma via alternativa para implantarmos um modelo de ensino/aprendizagem mais compatível com a história das ciências é promover as atividades heurísticas, como sendo uma ferramenta indispensável para a transposição do conhecimento do professor para o aluno e como um subsídio para o aprendiz construir o seu próprio conhecimento. Para [27], podese dizer que,

Ao utilizar o método heurístico, o professor deverá conduzir a atividade de maneira que o aluno consiga, na medida do possível, descobrir sozinho as verdades matemáticas, não permitindo, então, que o mesmo se torne um receptor passivo de conhecimentos. Essa descoberta deverá se dar por meio da resolução de problemas, que visam orientar a pesquisa de teoremas e o desenvolvimento do raciocínio lógico, que serão orientados através de questionários intimamente coordenados. O aluno deverá ter contato primeiramente com as noções intuitivas, com exemplos concretos e, se possível, instrumentos móveis, para posteriormente obter um conhecimento tácito sobre as proposições empregadas, ou seja, parte-se do conhecimento intuitivo para atingir posteriormente a Matemática mais formal e dedutiva.(PIRES et al, ALVAREZ, 2003, pg. 3)

Assim, acho conveniente disseminar na educação matemática o papel da heurística para a formação científica do aluno, desvinculando o método de ensino euclidiano ou dedutivista, que pode ser considerado o modelo tradicional, como a única alternativa de ensino. Como podemos observar em [21],

O estilo dedutivista, rompe as definições geradas pela prova dos antepassados, apresenta-as no vazio, de modo artificial e autoritário. Ele oculta os contra-exemplos globais que levaram ao seu descobrimento. Pelo contrário o estilo heurístico acentua esses fatores. Dá ênfase à situação problemática: acentua a "lógica" que deu nascimento ao novo conceito. (LAKATOS, 1978, pg. 188)

Diante dessa perspectiva, mostraremos a seguir algumas possibilidades de ensino de resolução dos três problemas clássicos da matemática grega que podem incentivar os estudantes a buscar novos mecanismos para resolver estes problemas. Com isso, estaremos alimentando a capacidade inventiva dos aprendizes, o que promoverá um ambiente propício à manifestação das atividades heurísticas, que como já discutido, é algo necessário para desenvolver o intelecto. 


\subsection{Dinamizando a resolução do problema da duplicação do cubo por meio de dobraduras}

Uma alternativa pedagógica para estimular os alunos a resolver o problema da duplicação do cubo é através de dobraduras, conhecido como origami. Para tanto, tomando como referência [25] e [6] mostrarei aqui uma sequência que serve para o professor guiar os alunos a encontrar a solução, no entanto, é válido ressaltar que como estamos partindo de princípios heurísticos, então é fundamental que o professor apenas guie os alunos, deixando-os livres a propor novos caminhos que chegam à resolução do problema.

O primeiro passo é o professor distribuir entre os alunos uma folha de papel quadrada e pedir para que eles, usando apenas dobraduras, tracem duas dobras paralelas que dividem o quadrado em três partes iguais. Uma alternativa para isso é: marcar o ponto médio da borda direita e marcar uma dobra ligando este ponto médio com o vértice inferior esquerdo do quadrado, dobrando e abrindo o papel, conforme figuras abaixo:
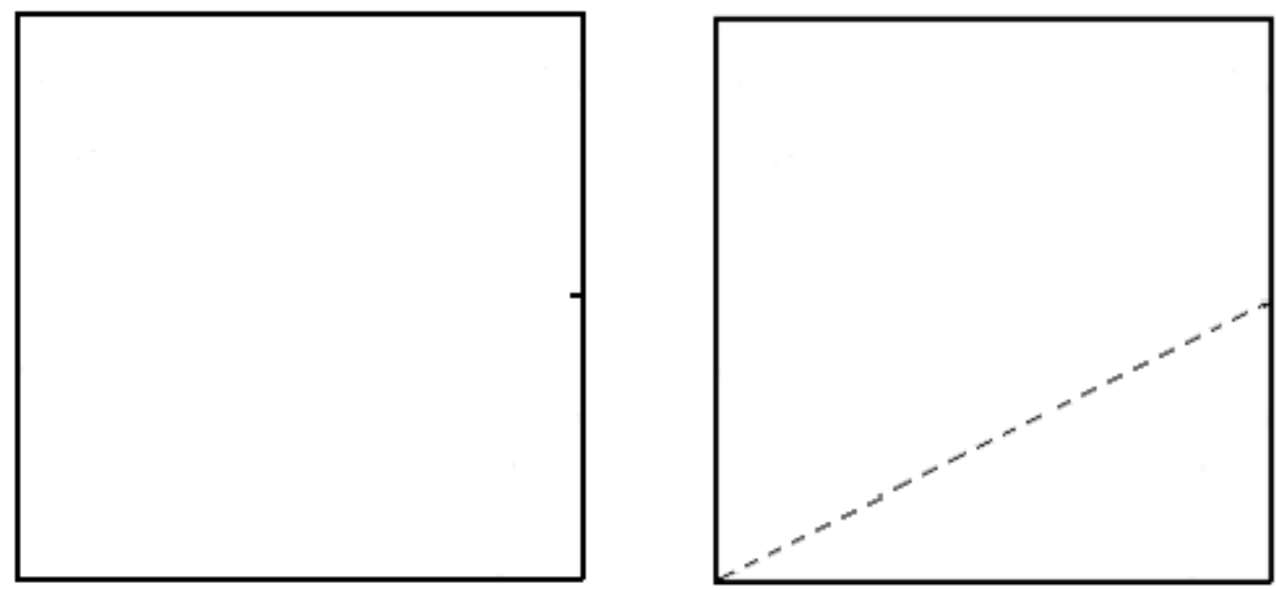

Em seguida, dobrando e abrindo o papel, tracemos uma diagonal do quadrado que intercepte a reta marcada anteriormente em um ponto. Conforme figuras abaixo: 
4. Implicações educacionais dos três problemas clássicos da matemática grega para o ensino
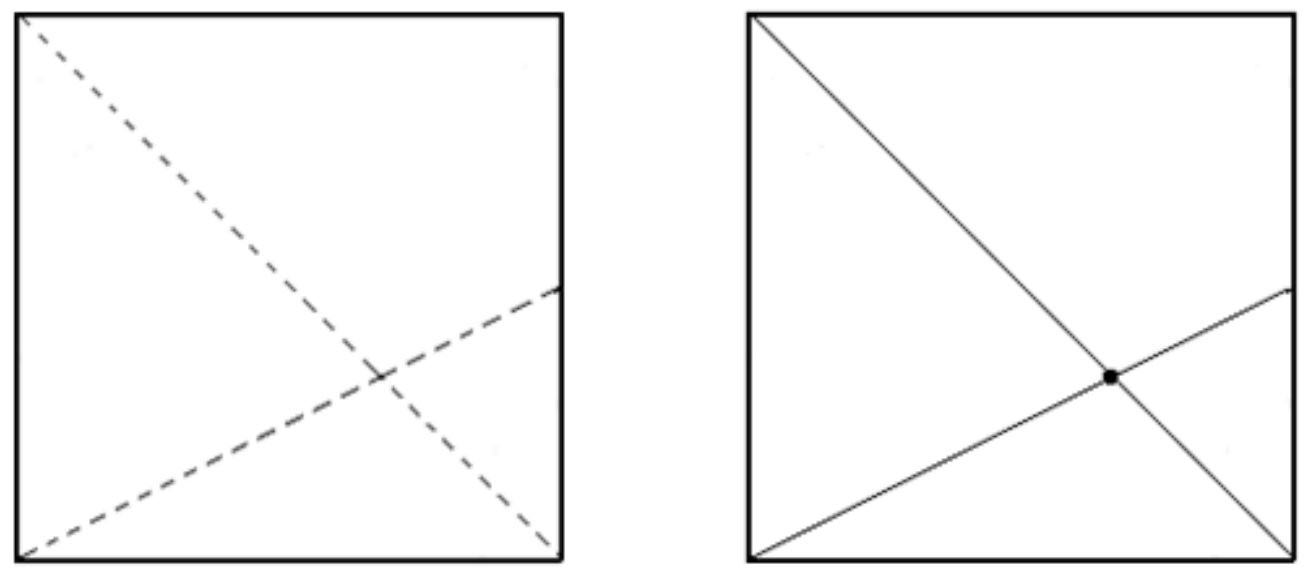

Logo após, dobrando e abrindo o papel, tracemos uma dobra que passa pelo ponto descrito anteriormente e que é paralela a borda inferior do quadrado e, por último, dobramos a borda superior do quadrado fazendo-a coincidir com a dobra descrita no passo anterior. Formando assim uma segunda reta, conforme a seguinte figura:
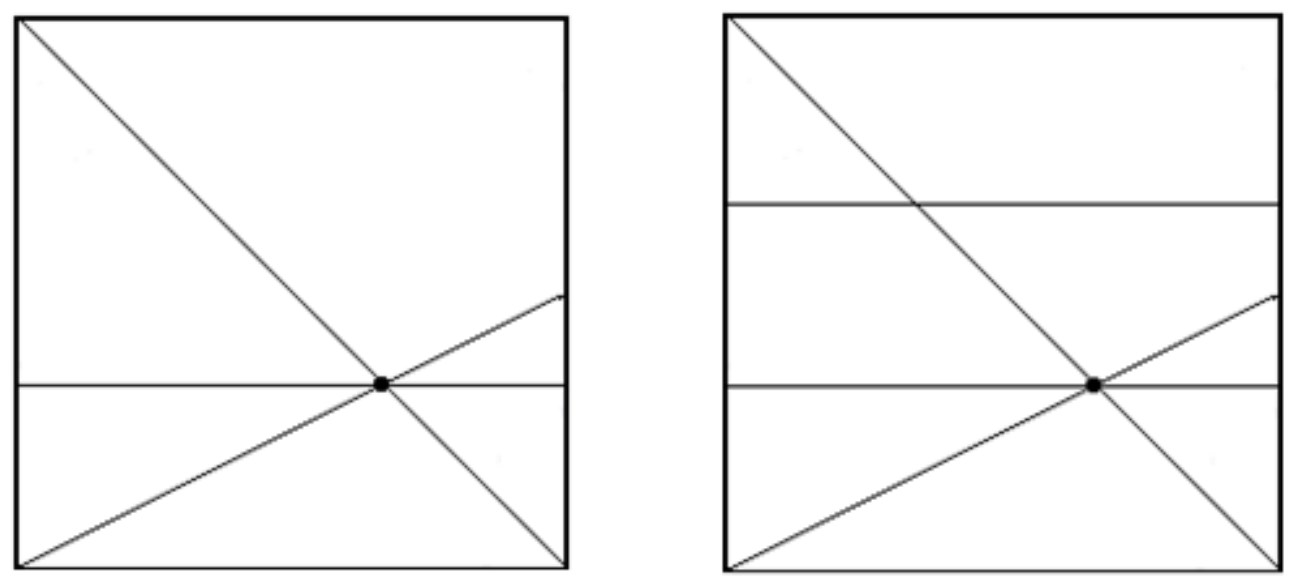

Com isso, as duas dobras traçadas horizontalmente no quadrado o dividem em três partes iguais. Para provar isso podemos fazer o seguinte: coloquemos o quadrado, cujo lado a designemos ter comprimento L, em um par de eixos cartesianos, com origem no vértice inferior esquerdo do quadrado, conforme a imagem seguinte. 


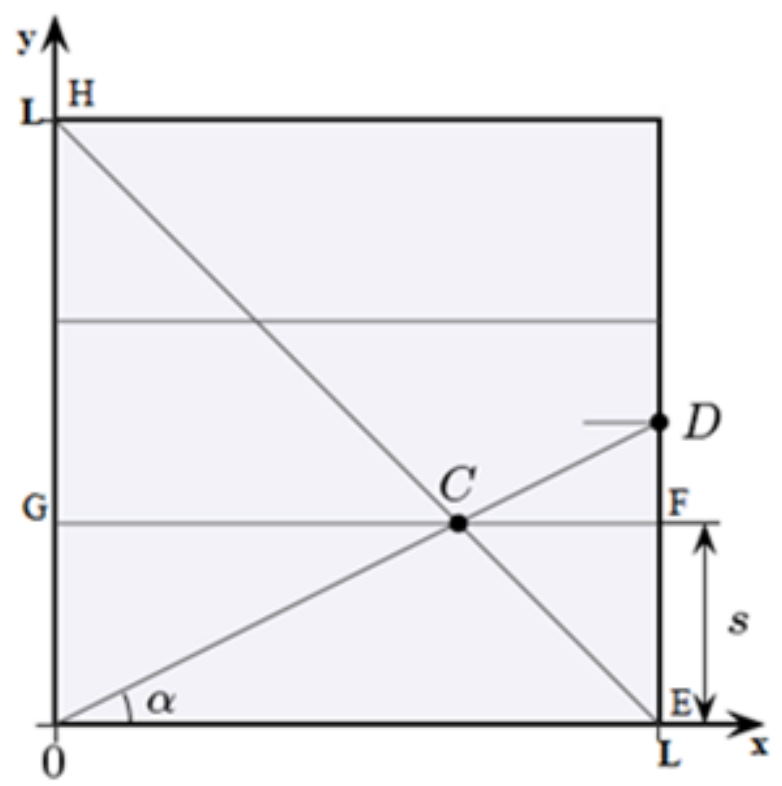

Observe que, por construção, o ângulo $C \hat{F} E=90^{\circ}$ e o ângulo $C \hat{E} F=45^{\circ}, \operatorname{logo}$ o ângulo $E \hat{C} F=45^{\circ}$. Assim, o triângulo $C F E$ é isósceles e retângulo, com isso, $C F=F E=S$. Assim, as coordenadas do ponto $C$ serão $C=(L-S, S)$. Já as coordenadas do ponto $D$ serão $D=\left(L, \frac{L}{2}\right)$.

Temos ainda que os ângulos $D \hat{O} E=\alpha=D \hat{F} C=G \hat{C} O$ e $O \hat{E} D=O \hat{G} C=90^{\circ}$. Assim, temos dois triângulos semelhantes $D O E$ e $O C G$, logo do triângulo $D O E$ segue que:

$$
\tan \alpha=\frac{\frac{L}{2}}{L}=\frac{1}{2}
$$

Já do triângulo OCG segue que:

$$
\tan \alpha=\frac{S}{L-S}
$$

Assim, $\frac{S}{L-S}=\frac{1}{2}$, logo, $2 S=L-S$, então $3 S=L$, e assim, $S=\frac{L}{3}$. Por construção, temos que os outros dois retângulos superiores também terão largura igual a $\frac{L}{3}$.

Essa é apenas uma das diversas maneiras de dividir uma folha quadrada em três partes congruentes e retangulares, usando apenas dobraduras. Logo, é ideal que o professor peça aos alunos que apresentem outras soluções que demonstrem tais resultados.

Agora, com o quadrado dividido em três partes congruentes e retangulares, marquemos os pontos $A$ e $B$, e em seguida, dobremos o vértice $A$ de tal forma que o ponto $B$ fique sobre a primeira reta horizontal e o ponto $A$ fique sobre a borda 
direita do quadrado, conforme figuras a seguir:
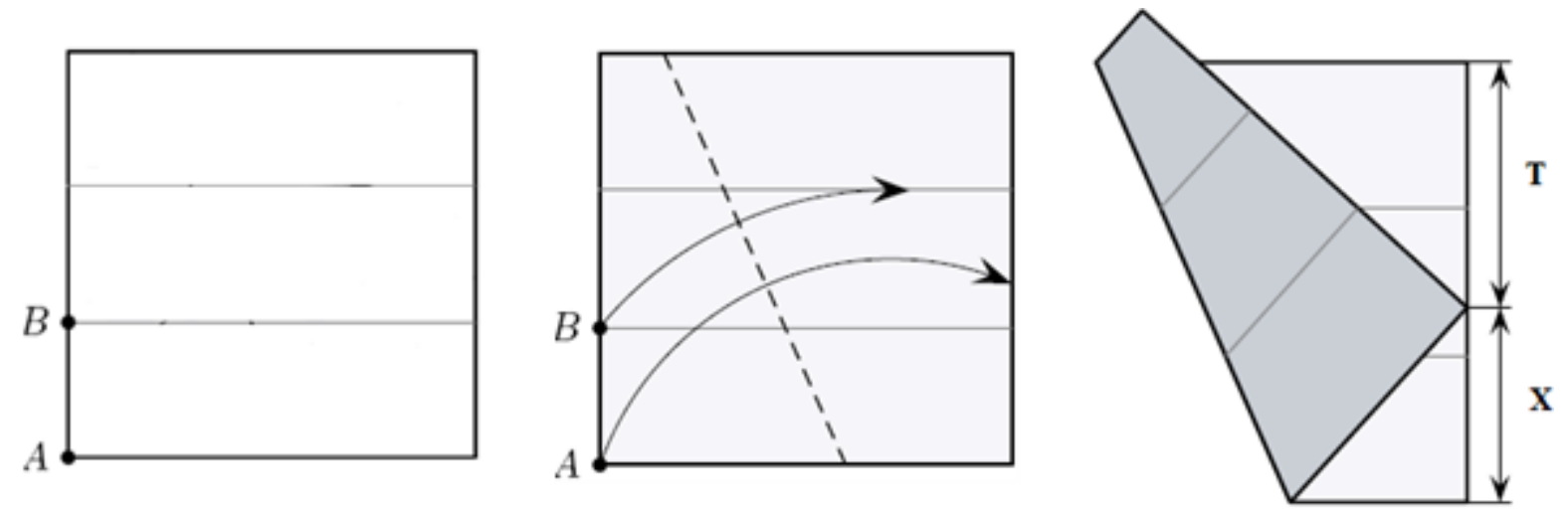

Afirmamos que o segmento superior determinado pelo ponto $A$ na borda direita do quadrado, tem medida $T=x \sqrt[3]{2}$ em que $x$ é o segmento representado na figura anterioir. Para provar esse resultado marquemos os pontos $A^{\prime}, B^{\prime}, C, D$ e $E$ como na figura abaixo e chamemos o comprimento do segmento $\overline{E A^{\prime}}=X$, conforme ilustração a seguir.

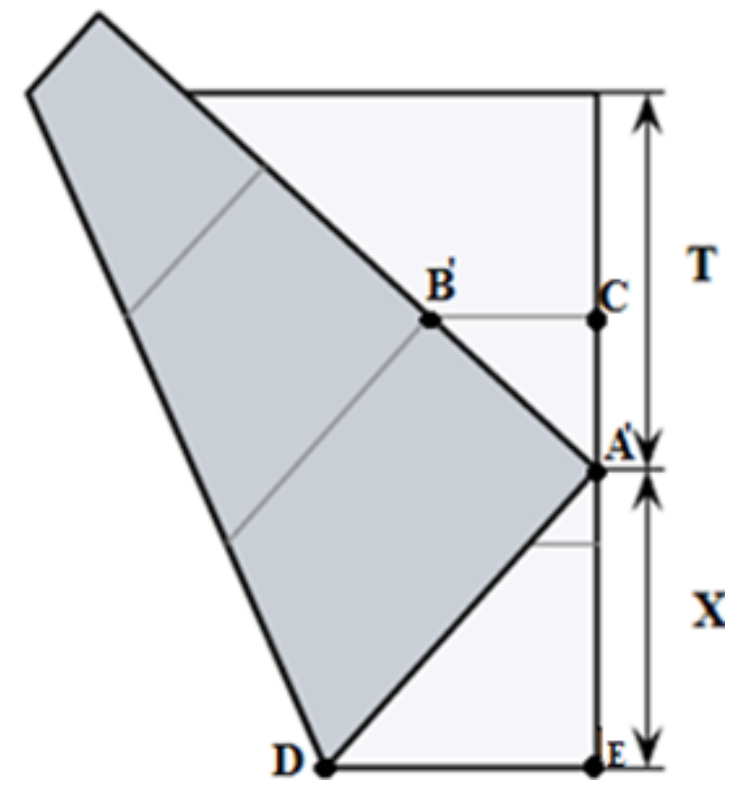

Assim, como tinhamos tomado inicialmente que o comprimento do lado do quadrado é $L$, então segue que $L=X+T$. Agora, utilizando o teorema de Pitágoras no triângulo $D A E$ teremos que $\left(\overline{A^{\prime} D}\right)^{2}=(\overline{D E})^{2}+\left(\overline{E A^{\prime}}\right)^{2}$, logo, fazendo $(\overline{D E})=a$, teremos:

$$
(X+T-a)^{2}=a^{2}+X^{2} .
$$

Assim, 


$$
(X+T)^{2}-2 a(X+T)+a^{2}=a^{2}+X^{2} .
$$

Com isso,

$$
X^{2}+2 X T+T^{2}-2 a(X+T)=X^{2} .
$$

Então, $2 X T+T^{2}=2 a(X+T)$. Portanto:

$$
a=\frac{2 X T+T^{2}}{2 X+2 T} .
$$

Podemos observar também que $\overline{A^{\prime} C}=T-\frac{X+T}{3}=\frac{2 T-X}{3}$. Além disso, como por construção os ângulos $D \hat{E} A^{\prime}, B^{\prime} \hat{C} A$ e $B^{\prime} \hat{A} D$ são retos e $E \hat{A}^{\prime} C=D \hat{A}^{\prime} E+B^{\prime} \hat{A}^{\prime} D+$ $B^{\prime} \hat{A}^{\prime} C=180^{\circ}$. Então segue que $B^{\prime} \hat{A}^{\prime} C+D \hat{A}^{\prime} E=90^{\circ}$ e $A^{\prime} \hat{B}^{\prime} C+B^{\prime} \hat{A}^{\prime} C=90^{\circ}, \operatorname{logo}$, $B^{\prime} \hat{A}^{\prime} C+D \hat{A}^{\prime} E=A^{\prime} \hat{B}^{\prime} C+B^{\prime} \hat{A}^{\prime} C$ e consequentemente, $D \hat{A}^{\prime} E=A^{\prime} \hat{B}^{\prime} C$. Por isso, os triângulos $D A^{\prime} E$ e $A^{\prime} B^{\prime} C$ são semelhantes e disso segue que $\frac{D E}{D A^{\prime}}=\frac{A^{\prime} C}{A^{\prime} B^{\prime}}$. Logo:

$$
\frac{a}{X+T-a}=\frac{\frac{2 T-X}{3}}{\frac{X+T}{3}} .
$$

Então,

$$
\frac{a}{X+T-a}=\frac{2 T-X}{X+T} \text {. }
$$

Portanto,

$$
a X+a T=T X+2 T^{2}-2 a T-X^{2}+a X
$$

Logo,

$$
X^{2}+3 a T-T X-2 T^{2}=0
$$

Subistituindo 4.6, teremos:

$$
X^{2}+3 T \frac{2 X T+T^{2}}{2 X+2 T}-T X-2 T^{2}=0
$$

Logo,

$$
X^{2}+\frac{6 X T^{2}+3 T^{3}}{2 X+2 T}-T X-2 T^{2}=0
$$

Assim, 


$$
\frac{6 X T^{2}+3 T^{3}}{2 X+2 T}=T X+2 T^{2}-X^{2}
$$

Então,

$$
6 T^{2} X+3 T^{3}=2 T X^{2}+4 T^{2} X-2 X^{3}+2 T^{2} X+4 T^{3}-2 T X^{2}=4 T^{3}+6 T^{2} X-2 X^{3} .
$$

Portanto,

$$
6 T^{2} X+3 T^{3}=4 T^{3}+6 T^{2} X-2 X^{3} .
$$

Assim, $T^{3}-2 X^{3}=0$, então, $T=X \sqrt[3]{2}$.

Com isso, conseguimos construir um segmento $T$ que mede $X \sqrt[3]{2}$. Agora, fazendo a divisão do segmento $X \sqrt[3]{2}$ por $X$, construiremos um segmento de comprimento $\sqrt[3]{2}$. Uma sugestão para fazer essa divisão com dobraduras é traçarmos novamente uma diagonal do quadrado e dobrar a folha de modo que a borda direita, onde estão traçados os dois segmentos $X$ e $T$, fique exatamente sobre a diagonal. Assim, transferiremos o segmento $\overline{F G}=X=\overline{F G^{\prime}}$ e $\overline{G H}=X \sqrt[3]{2}=\overline{G^{\prime} H^{\prime}}$ para a diagonal, conforme imagens seguintes:
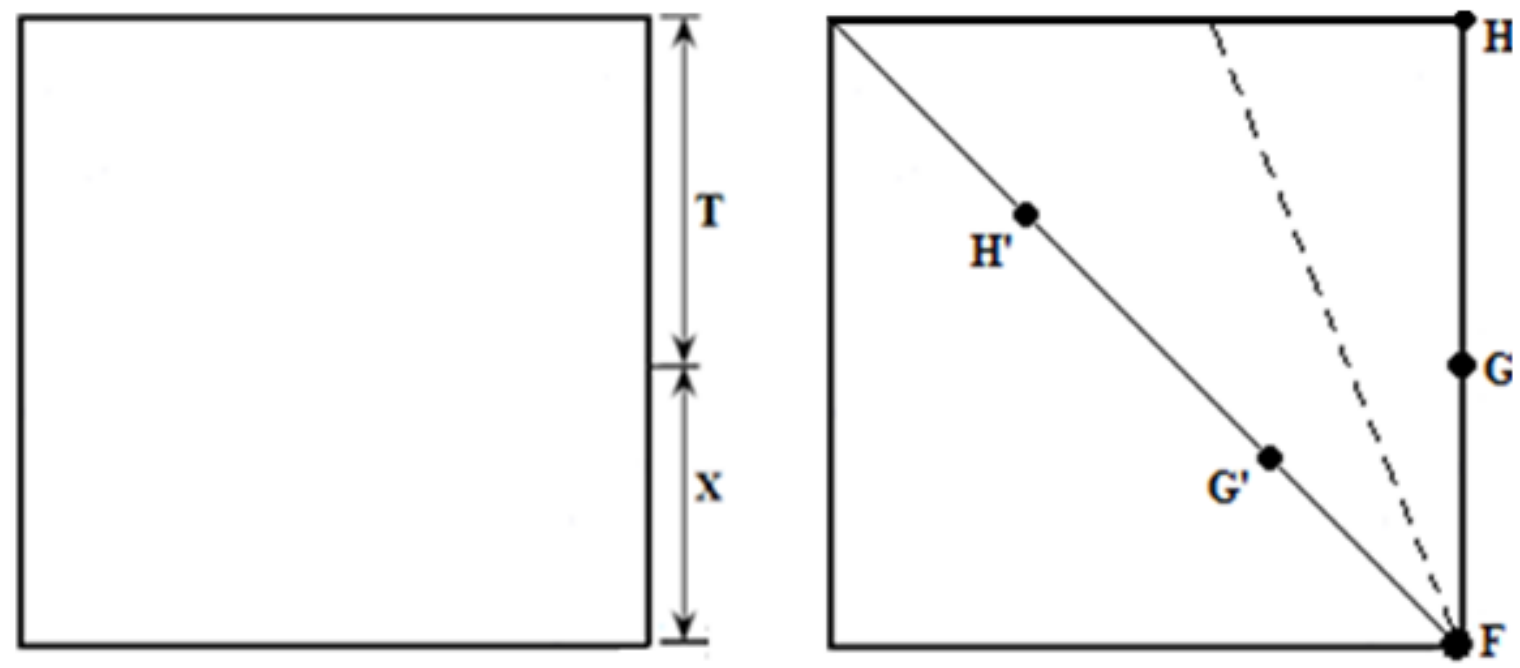

Logo em seguida, transferiremos o segmento $\overline{G^{\prime} H^{\prime}}$ para o lugar do segmento $\overline{F G^{\prime}}$, isto é, transladamos o segmento $\overline{G^{\prime} H^{\prime}}$, fazendo com que a extremidade $H^{\prime}$ coincida com o ponto $F$. Isso é possível dobrado a folha de modo que o ponto $H^{\prime}$ fique exatamente sobre o ponto $F$ e marcamos a sombra feita pelo ponto $G^{\prime}$ no verso da folha e em seguida passamos esse ponto para a parte da frente da folha, conforme ilustrações seguintes: 
4. Implicações educacionais dos três problemas clássicos da matemática grega para o ensino
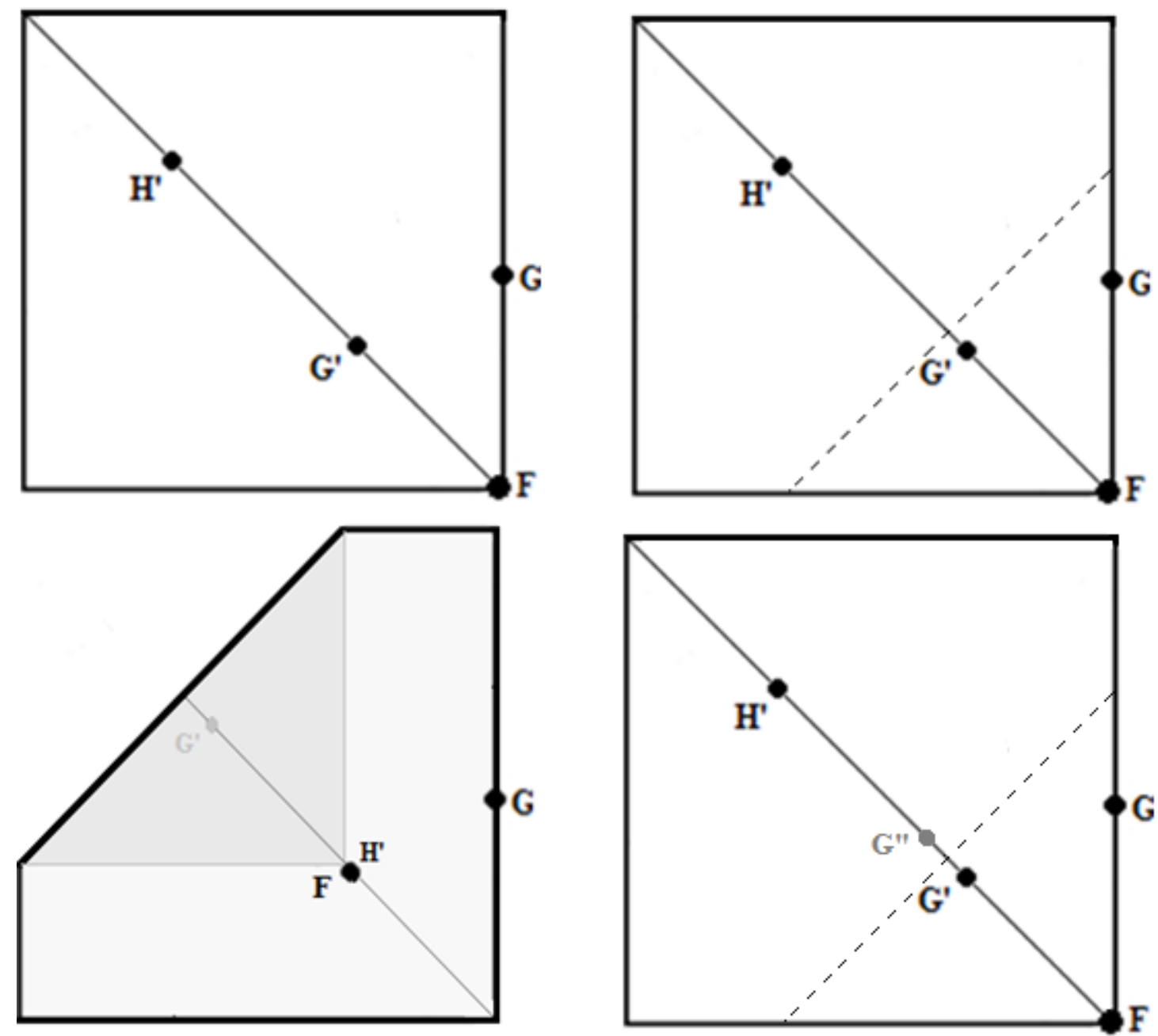

Assim, como a reta pontilhada acima é a mediatriz do segmento $\overline{F H^{\prime}}$ e $G^{\prime \prime}$ é a reflexão de $G^{\prime}$ quando dobramos a folha na mediatriz, então segue que $\overline{G^{\prime} H^{\prime}}=\overline{F G^{\prime \prime}}$.

Logo após, peguemos o segmento unitário, previamente determinado, $\overline{G J}=1 \mathrm{e}$ o coloquemos junto do segmento $\overline{F G}$, conforme as seguintes figuras. 
4. Implicações educacionais dos três problemas clássicos da matemática grega para o ensino
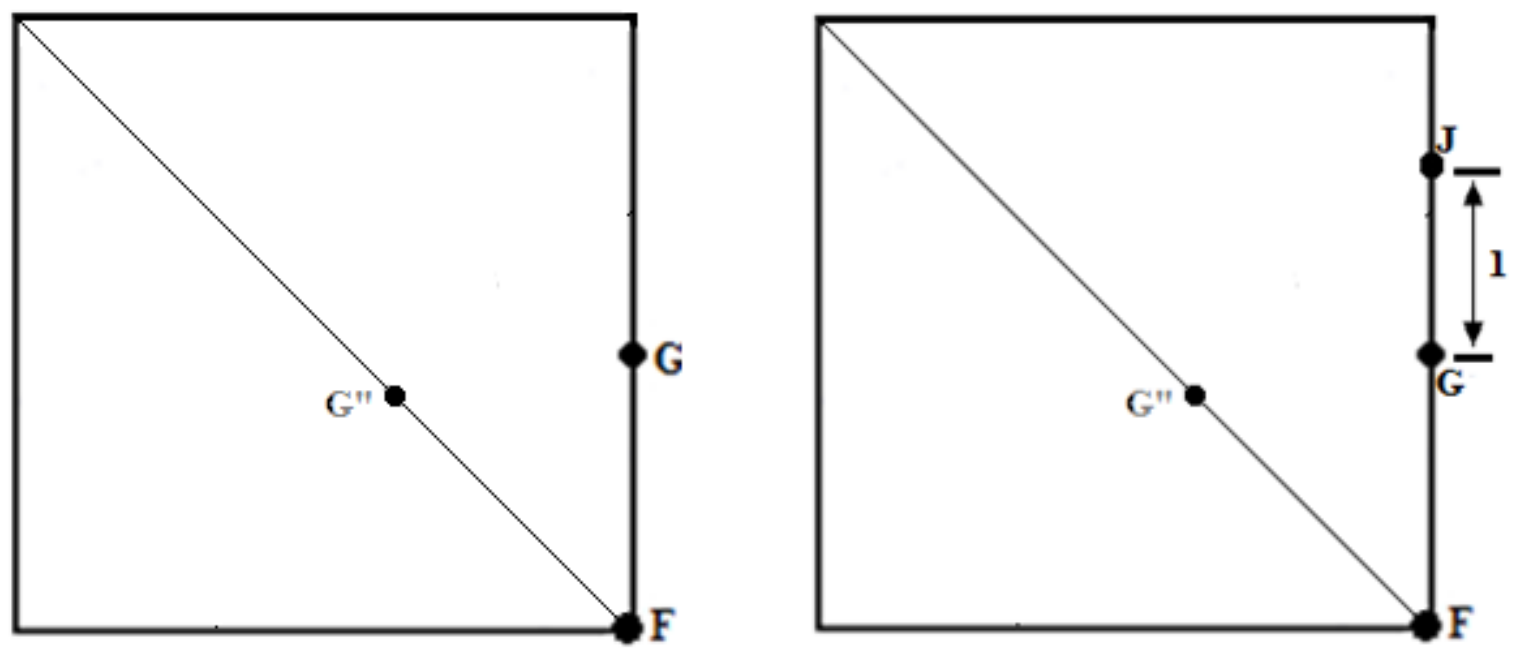

Dobrando e abrindo o papel, tracemos uma reta ligando os pontos $G$ e $G^{\prime \prime}$ e, em seguida, dobremos a borda direita do quadrado formando uma reta $m$ de tal modo que o ponto $G$ fique exatamente sobre o segmento $\overline{G G^{\prime \prime}}$, traçando um ponto $G^{\prime \prime \prime}$ e, assim, o ponto $J$ terá uma nova posição que chamaremos de $J^{\prime}$. Com isso, os segmentos $\overline{G G^{\prime \prime}}$ e $\overline{J J^{\prime}}$ serão paralelas, pois, por construção $\overline{G J}=\overline{G^{\prime \prime \prime} J^{\prime}}$. Logo, o prolongamento dos segmentos de reta $\overline{F G^{\prime \prime}}$ e $\overline{J J^{\prime}}$ se interceptarão em um ponto $k$, conforme ilustrações seguintes. 

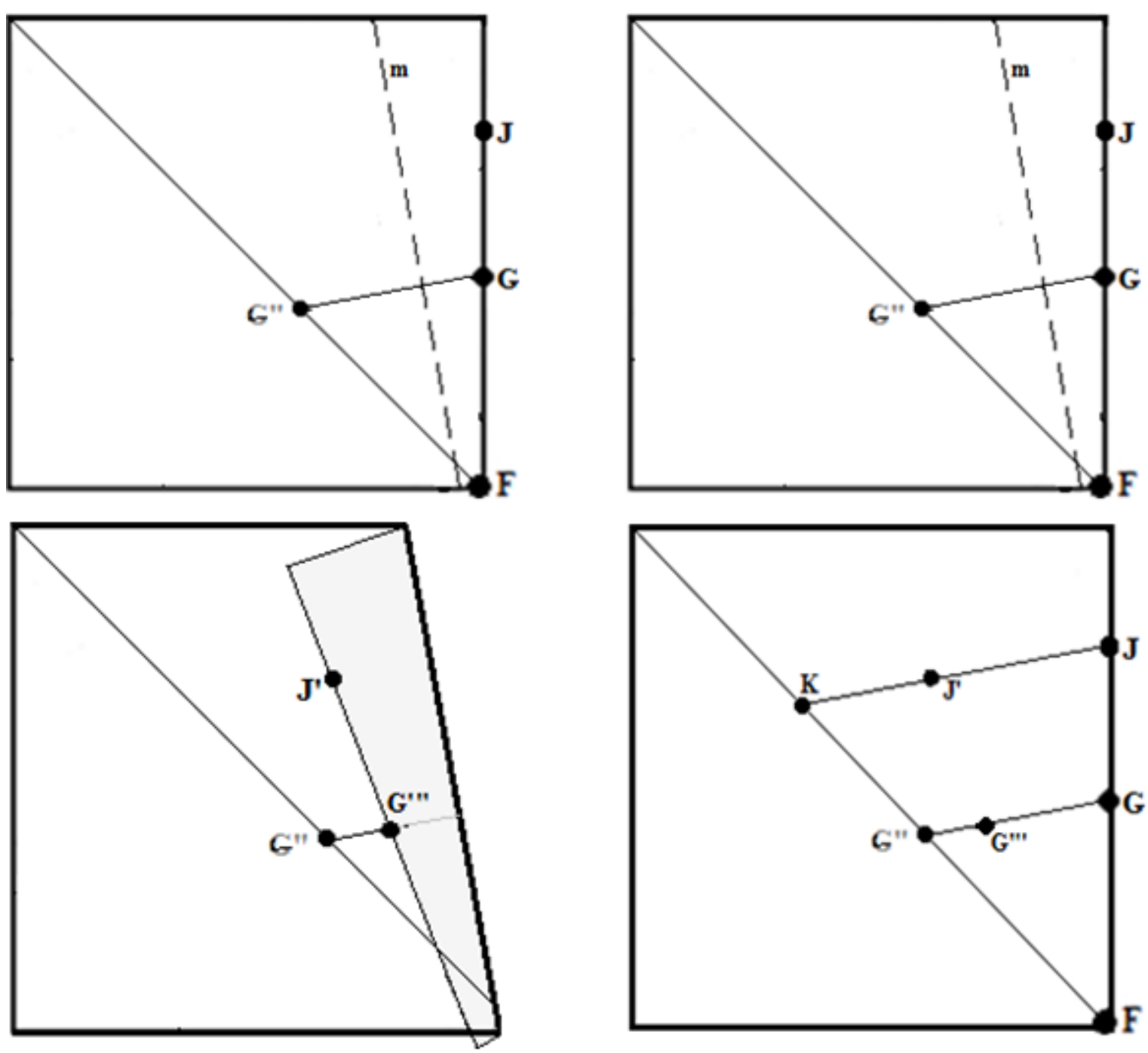

Com isso, segue que o segmento $\overline{G^{\prime \prime} K}$ tem comprimento $\sqrt[3]{2}$. De fato, pelo teorema de Tales temos que $\frac{\overline{F G}}{\overline{G J}}=\frac{\overline{F G^{\prime \prime}}}{\overline{G^{\prime \prime} K}}$, portanto, $\frac{X}{1}=\frac{X \sqrt[3]{2}}{\overline{G^{\prime \prime} K}}, \operatorname{logo}, X \cdot \overline{G^{\prime \prime} K}=X \sqrt[3]{2}$, sendo assim, $\overline{G^{\prime \prime} K}=\frac{X \sqrt[3]{2}}{X}$, isto é, $\overline{G^{\prime \prime} K}=\sqrt[3]{2}$

Assim, construímos um segmento cujo comprimento é $\sqrt[3]{2}$. Para resolver o problema da duplicação do cubo, vamos supor que temos um cubo de aresta $Z$, logo seu volume será $Z^{3}$, então para duplicá-lo, devemos construir outro cubo de aresta $Y$ cujo volume deve ser $2 Z^{3}$. No entanto, o volume do cubo de aresta $Y$ também é dado por $Y^{3}$, logo, $Y^{3}=2 Z^{3}$, então, $Y=Z \sqrt[3]{2}$. Assim, devemos construir um segmento de comprimento $Z \sqrt[3]{2}$.

Como já temos um segmento de comprimento $\sqrt[3]{2}$, então devemos traçar o segmento de comprimento $Z$ e multiplicá-lo pelo segmento $\sqrt[3]{2}$. Para tanto, vamos transportar o segmento $\sqrt[3]{2}$ e o segmento unitário de modo que uma das extremidades de cada segmento fique exatamente sobre $F$, que é o vértice inferior direito do quadrado, isso é possível seguindo os mesmos passos que fizemos anteriormente para 
transportar o segmento $X \sqrt[3]{2}$. Conforme ilustrações seguintes, as retas $p$ e $q$ é onde devemos dobrar o quadrado para transpor os segmentos $\sqrt[3]{2}$ e 1 , respectivamente:
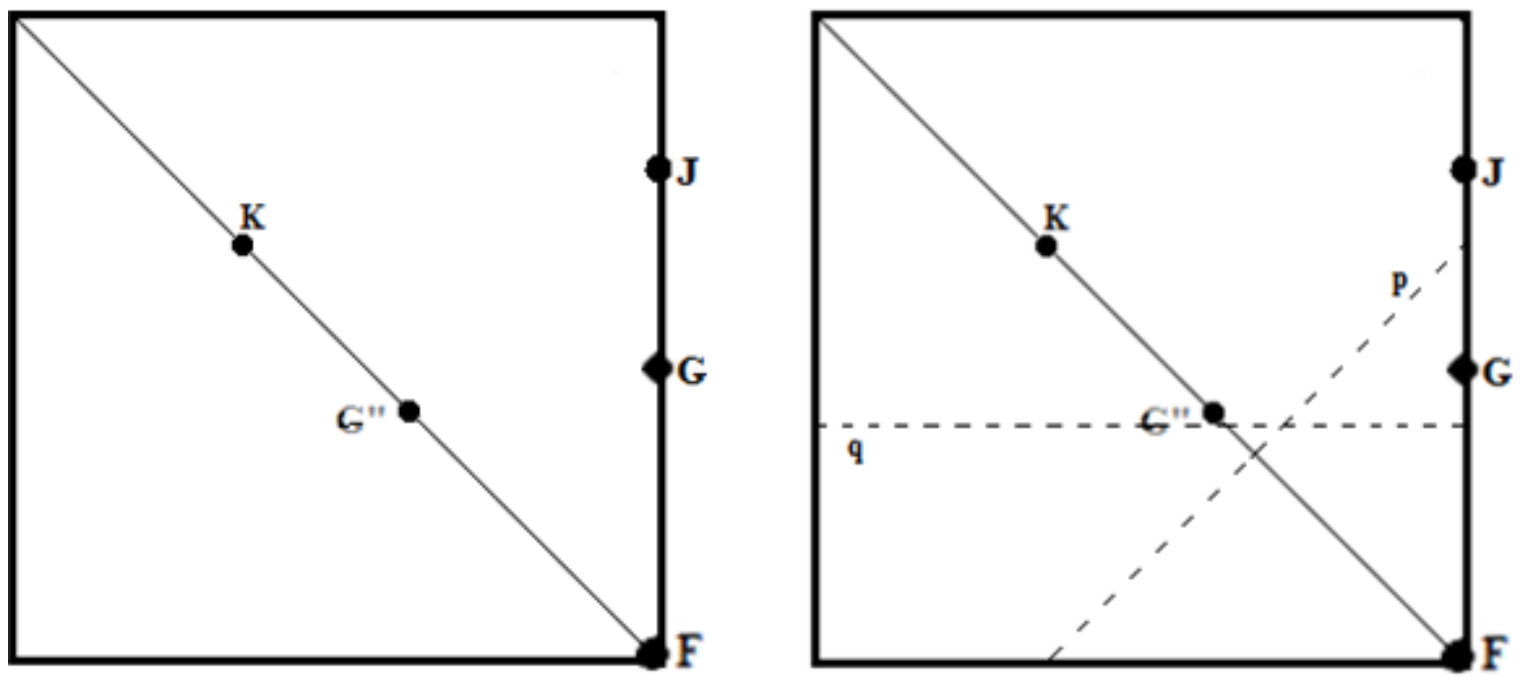

Assim temos que o ponto $R$ é a reflexão do ponto $G$ " quando dobramos a folha na reta $p, \log o, \overline{F R}=\overline{G^{\prime \prime} K}=\sqrt[3]{2}$. Da mesma forma, o ponto $U$ é a reflexão do ponto $G$ quando dobramos a folha na reta $q$, assim, $\overline{F U}=\overline{J G}=1$. Conforme a próxima figura.

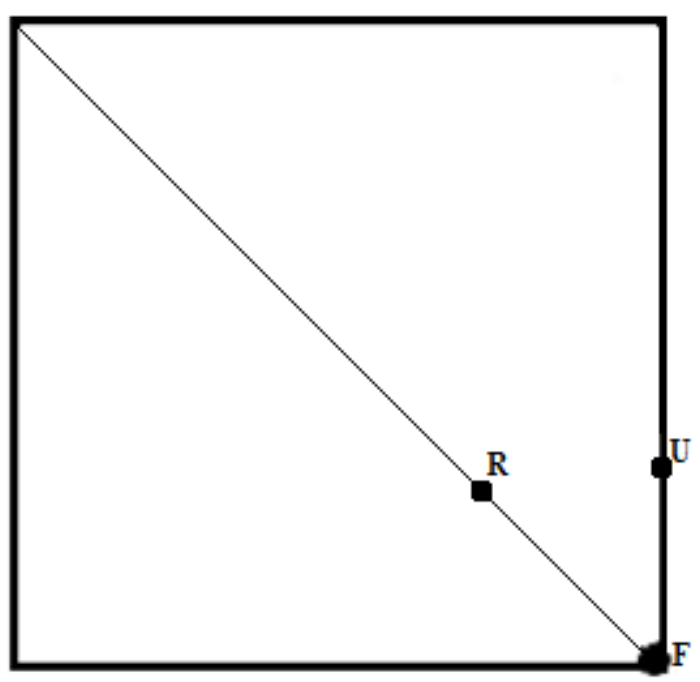

Em seguida, adicionamos junto do segmento unitário $\overline{F U}$ o segmento de comprimento $Z=\overline{U W}$, que é a aresta do cubo a duplicar. Após, unimos os pontos $U$ e $R$ e tracemos uma reta que passa por $W$ e é paralela a $\overline{U R}$ (essa construção é análoga a que fizemos anteriormente para traçar uma reta paralela a $\overline{G G^{\prime \prime}}$ e que passa pelo ponto $J$ ), interceptando o prolongamento do segmento $\overline{F R}$ no ponto $N$, conforme imagens a seguir. 


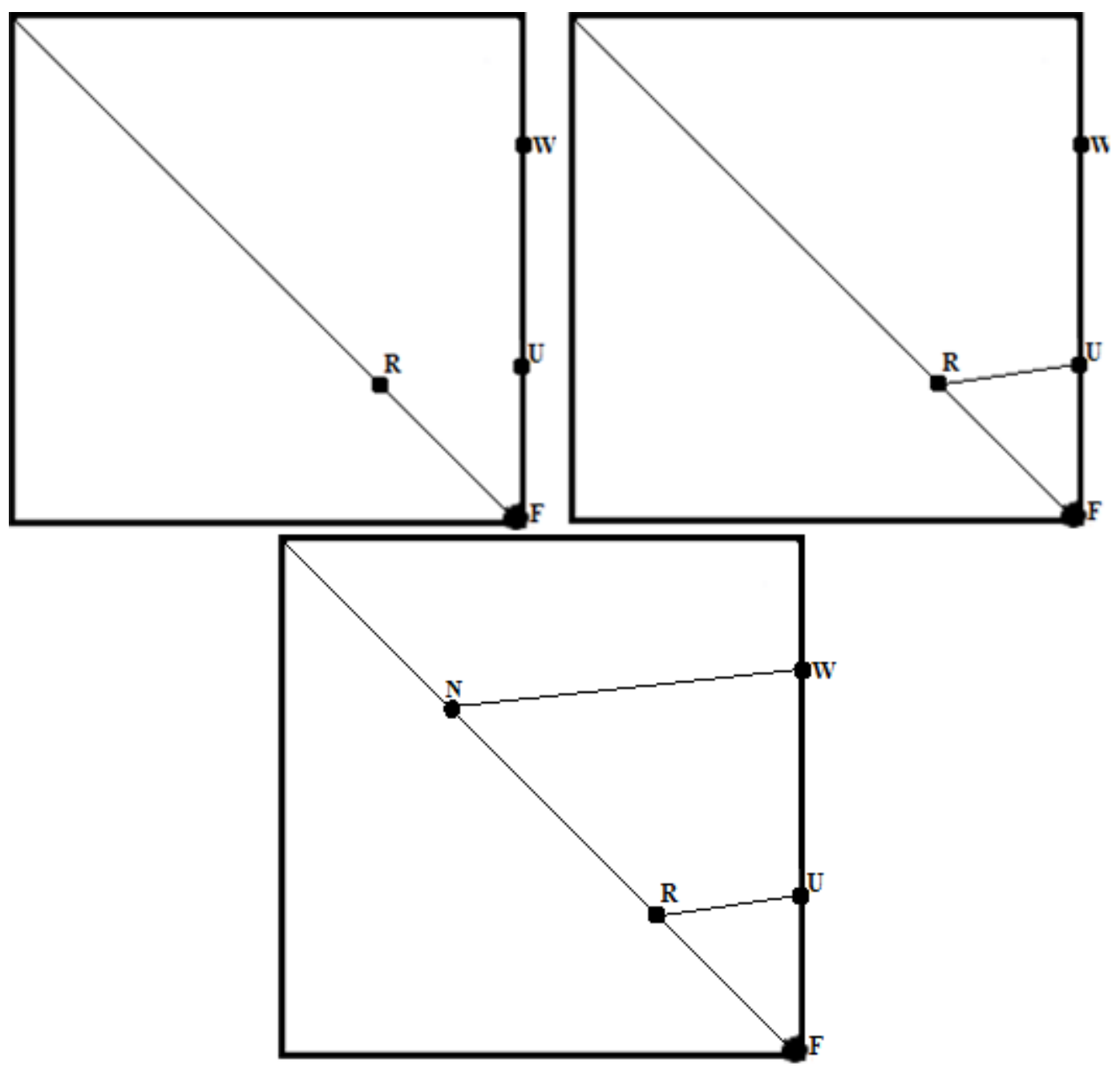

Assim, temos que o segmento $\overline{R N}=Z \sqrt[3]{2}$. De fato, novamente pelo teorema de Tales, segue que $\frac{\overline{F U}}{\overline{U W}}=\frac{\overline{F R}}{\overline{R N}}$, logo, $\frac{1}{Z}=\frac{\sqrt[3]{2}}{R N}$, assim, $\overline{R N}=Z \sqrt[3]{2}$. Logo, está resolvido o problema da duplicação do cubo.

É importante observar que como $Z$ é um segmento de tamanho qualquer, então devemos tomar no início um quadrado de lado $L$ que seja suficientemente grande, de tal forma que $L \geq Z+1$. Além disso, deve ser usada folha vegetal para construir o quadrado, pois haverá a necessidade de sobrepor retas e pontos da folha.

Podemos analisar assim que esse tipo de atividade pode ser significante para promover a criatividade dos alunos, no tocante à busca de estratégias para tentar encontrar tipos de dobraduras que encaminhas a solução do problema. Também é importante que o professor dê a liberdade aos alunos de procurar demonstrar os resultados obtidos na folha quadrada através das dobraduras. Esse tipo de postura do professor pode promover no aluno um aprendizado mais significativo, influenciado pela ciência Heurística. 


\subsection{Utilizando a espiral de Arquimedes para resolver o problema da trissecção do ângulo - uma aplicação pedagógica}

A espiral de Arquimedes pode ser considerada como uma das curvas mecânicas mais importante, inventada muito provavelmente, para a busca de solucionar os três problemas clássicos aqui em questão.

Esta curva já foi tratada no capítulo anterior, onde mostramos sua funcionalidade para resolver a quadratura do círculo. Agora, faremos uma exposição de como construir a espiral em sala de aula e mostrar, de forma mais interativa, como solucionar a trissecção do ângulo.

Para tanto, vamos rever a definição que Arquimedes da a sua espiral:

Se uma linha reta for desenhada num plano e se, permanecendo fixa uma das suas extremidades, ela girar com uma velocidade uniforme um número qualquer de vezes até retomar à posição de que partiu e se, além disso, durante esta rotação da linha reta, um ponto se mover sobre a reta com uma velocidade uniforme a partir da extremidade fixa, o ponto descreverá uma espiral no plano. (Ver EECKE, 1960, pg. 261)

Para iniciar a construção e solução do problema, o professor deverá usar junto com os alunos régua, compasso, transferidor e/ou esquadro para construir a espiral. Assim, com estes instrumentos, obviamente não euclidianos, traçam-se duas retas perpendiculares entre si, formando uma representação do plano cartesiano. Em seguida, deve-se escolher uma unidade de comprimento, de tal forma que caibam no mínimo oito vezes este comprimento em cada um dos lados dos eixos determinados pela intersecção das duas retas perpendiculares e marcam-se a partir desta intersecção oito unidades de comprimento, conforme imagem: 


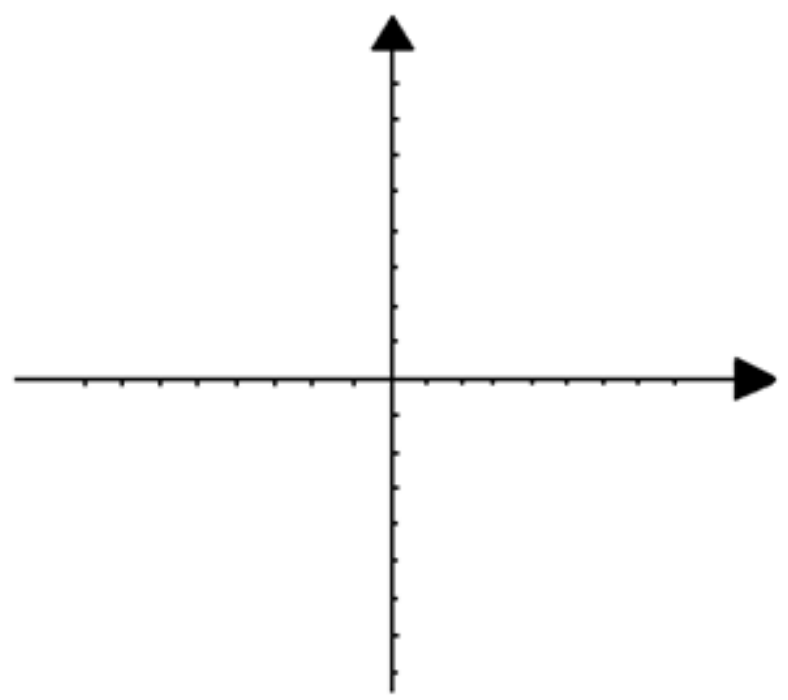

Assim, traçam-se oito circunferências concêntricas, cada uma com raio uma unidade de comprimento maior que a anterior, isto é, a primeira com raio igual a 1u.c, a segunda com raio 2u.c, e assim por diante, conforme ilustração.

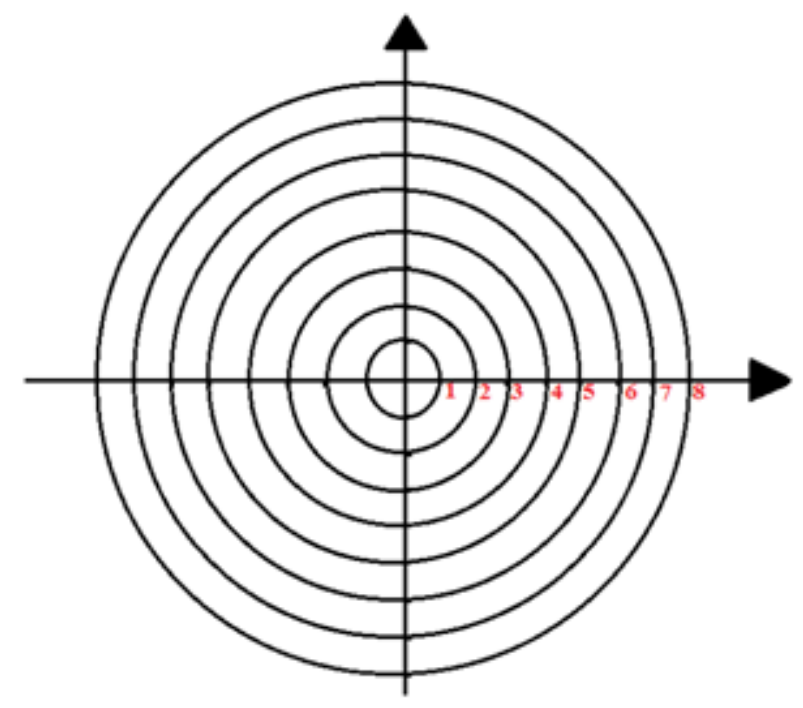

Em seguida, traçam-se duas retas que dividirão cada quadrante da figura anterior em duas partes iguais. Como cada um dos quadrantes medem $90^{\circ}$, então as retas devem ser traçadas de tal modo que cada quadrante fique dividido em dois ângulos de $45^{\circ}$ ( isso é possível usando o transferidor, mas também pode ser feito usando apenas a régua não graduada e compasso, como foi feito em $(1.2)$, a bissetriz de um ângulo), conforme imagem seguinte. 


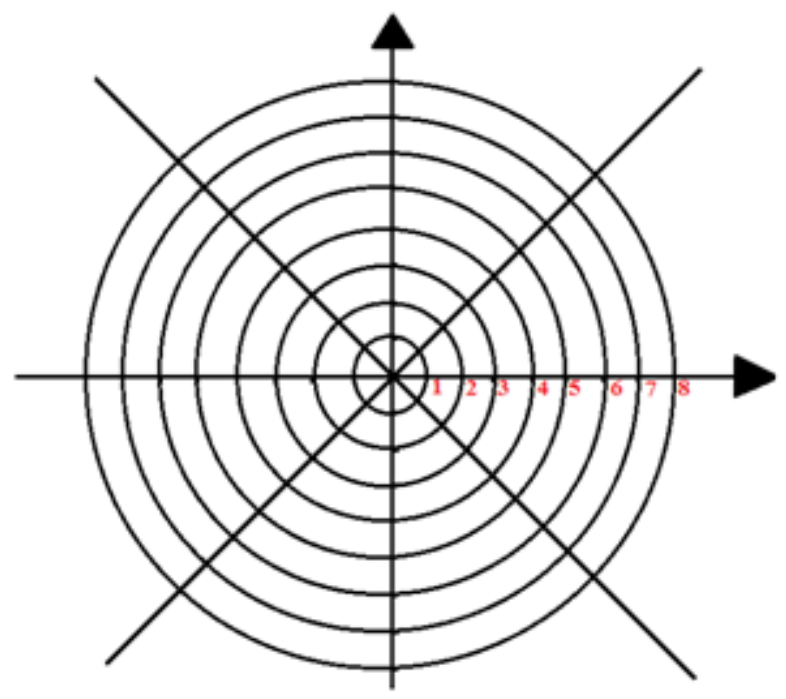

Logo após, escolhe um dos segmentos de reta traçados para ser o primeiro, e a partir deste, enumeram-se de 2 a 8 os outros segmentos, no sentido horário e marcam-se os pontos de intersecção da circunferência de raio 1u.c. com a semirreta 1 , a circunferência de raio 2 u.c. com a semirreta 2 e assim sucessivamente, conforme ilustração.
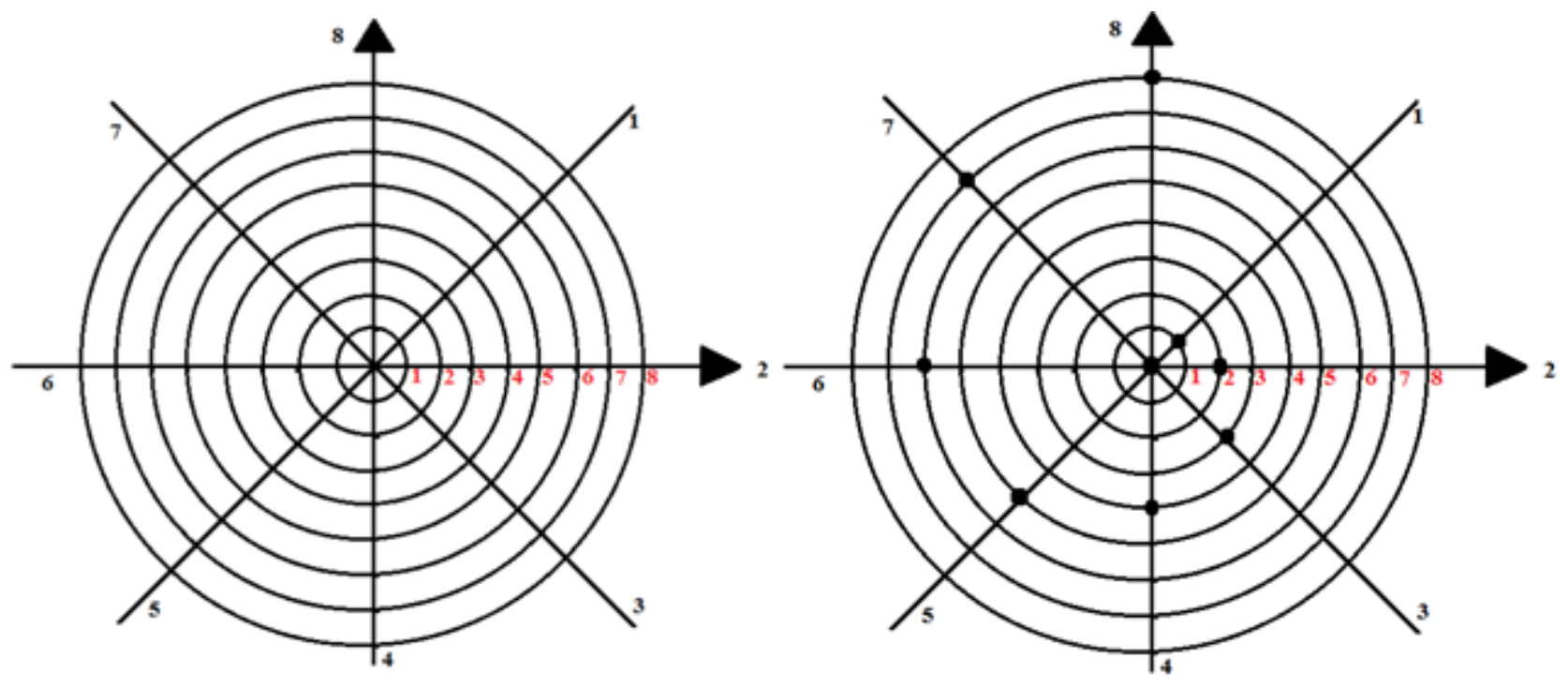

Por fim, ligamos com arcos os pontos de intersecção descritos anteriormente, e assim teremos traçado a espiral de Arquimedes, conforme figura: 


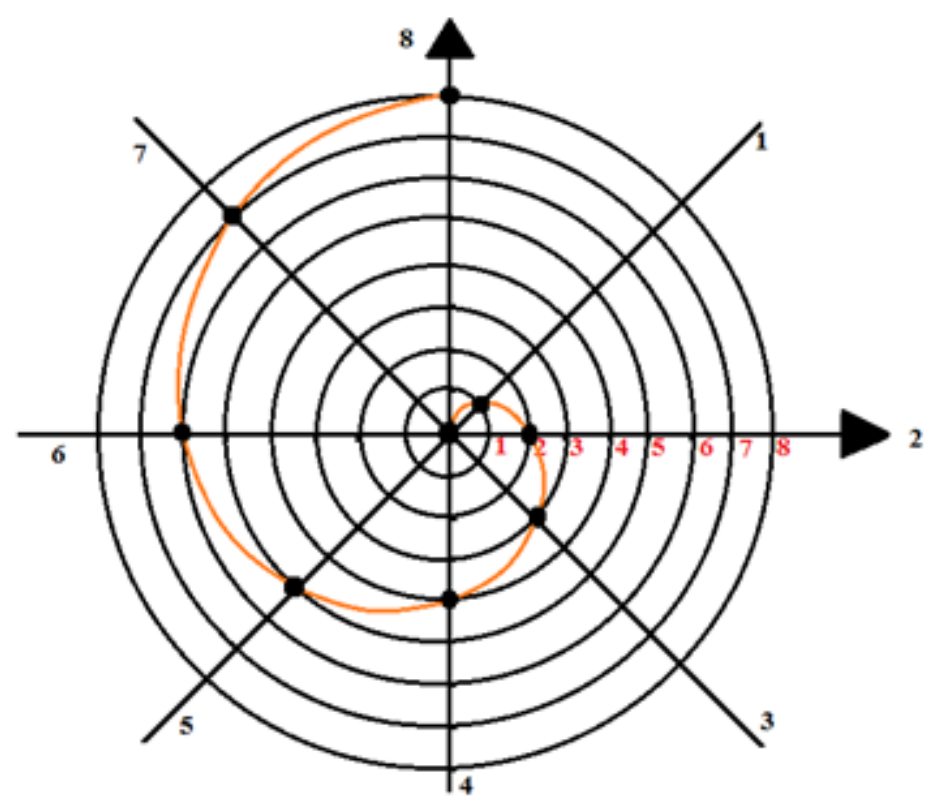

A partir dessa construção, o professor deve mostrar as principais propriedades da espiral, tomando como base o livro de Arquimedes Acerca das Espirais. No entanto, deve-se dá ênfase a proposição XIV deste livro, a qual irá ser utilizada durante a trissecção do ângulo. Nesta proposição Arquimedes demonstra que "Proposição XIV: Se, a partir da origem da espiral, se traçarem duas linhas retas até encontrarem a primeira volta da espiral, e se se prolongarem até encontrarem a circunferência do primeiro círculo, as linhas traçadas até à espiral terão entre si a mesma razão que os arcos da circunferência entre a extremidade da espiral e as extremidades das retas prolongadas até encontrarem a circunferência, sendo os arcos medidos para a frente a partir da extremidade da espiral." (SOUSA, 2001, pg. 26)

Assim, acompanhado a figura seguinte, Arquimedes demonstra que se $A$ e $D$ são dois pontos da curva espiral, com origem em $B$, então teremos que o segmento $\overline{B D}$ está para $\overline{B A}$, assim como o arco $\widehat{F D}$ está para o arco $\widehat{F E}$, isto é, $\frac{\overline{B D}}{\overline{B A}}=\frac{\widehat{F D}}{\widehat{F E}}$. Dessa forma, temos que a distância entre a origem da espiral, nesse caso $B$, e o ponto sobre a espiral, nesse caso $A$, é proporcional ao ângulo, cujos lados são a reta inicial 1 da curva, $B C$, e a reta $B A$.

\footnotetext{
${ }^{1}$ Arquimedes usava o termo reta inicial para designar a reta de revolução a partir da qual a reta começa a girar.
} 


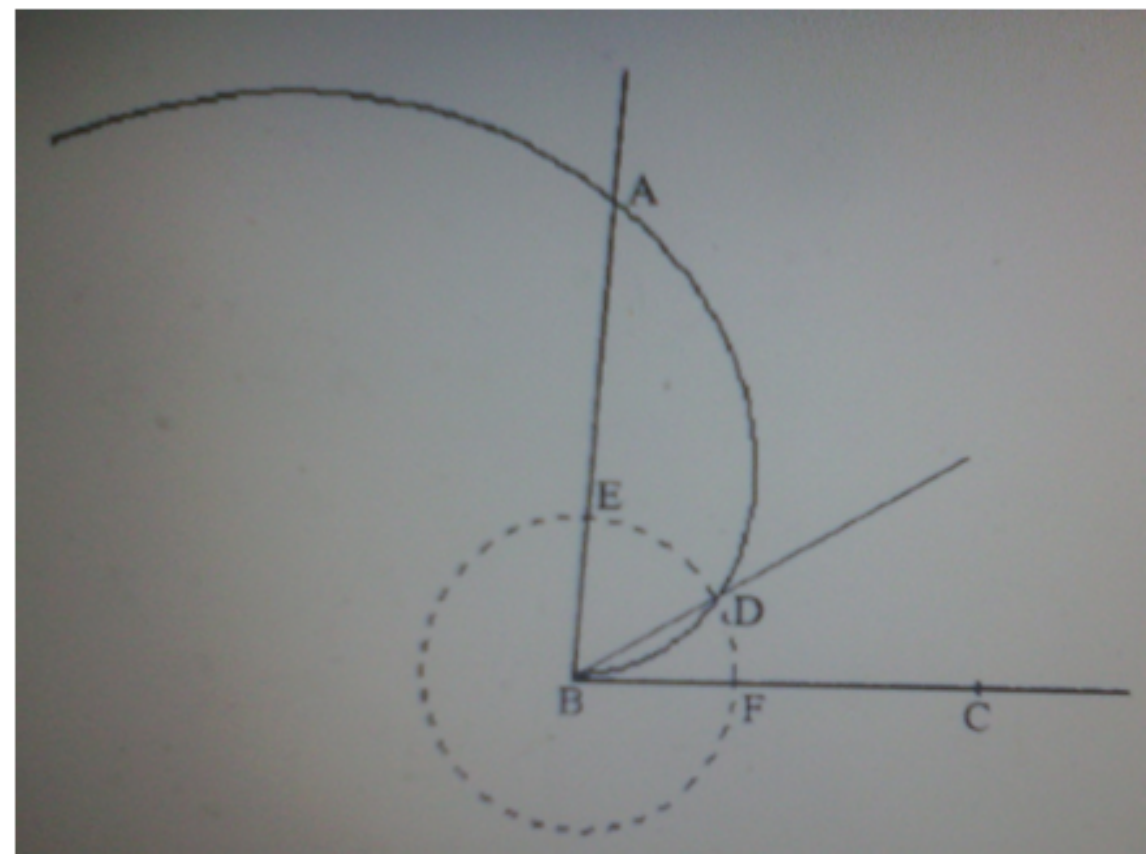

Digamos que pretendemos tissectar o ângulo agudo $A \hat{B} C$, como o da imagem acima. Assim, construímos a espiral com origem no ponto $B$, fazendo com que o lado $\overline{B C}$ do ângulo seja a reta inicial e o outro lado do ângulo, $\overline{B A}$, intersecta a espiral no ponto $A$.

Com isso, começamos a dividir o segmento $\overline{A B}$ em três partes iguais (construção possível apenas com régua sem marcas e compasso). Em seguida, marquemos $E$, de tal modo que $E=\frac{1}{3} \overline{A B}$ e após tracemos uma circunferência de centro em $B$ e raio $\overline{B E}$, que interceptará a espiral em $D$. Assim, o ângulo $D \hat{B} F$ é a terça parte do ângulo $A \hat{B} C$.

Para provar o resultado anterior basta observar que como a espiral relaciona comprimento de um segmento de reta, digamos $x$, com o ângulo gerado pelo segmento de reta a partir de sua posição inicial, digamos $\alpha$. Assim, em coordenadas polares teremos que $x=k \alpha$, onde $k$ é um numero real positivo. Agora, como $A$ e $D$ são pontos da espiral, então teremos que $\overline{B A}=k \alpha 1$ e $\overline{B D}=k \alpha 2$, onde $\alpha 1=A \hat{B} C$ e $\alpha 2=D \hat{B} C$.

Como temos que $E=\frac{1}{3} A B$ e $\overline{B E}=\overline{B D}$, então, $\overline{B A}=3 \overline{B E}=3 \overline{B D}$. Logo, $\overline{B A}=3 \overline{B D}=k \alpha 1$ e $\overline{B D}=k \alpha 2$, isto é, $3 k \alpha 2=k \alpha 1$, ou seja, $\alpha 2=\frac{\alpha 1}{3}$. Resolvendo assim o problema da trissecção do ângulo.

Essa construção da curva de Arquimedes pode ser uma alternativa pedagógica dinamizadora do processo de ensino e aprendizagem da matemática. Além de ser uma atividade interativa, o professor estará promovendo o ensino pelo viés históricoepistemológico, que está intimamnete ligado com heurística. 


\section{CONCLUSÃO}

Este trabalho de pesquisa foi desenvolvido com a intenção de analisar e mostrar o potencial heurístico trazidos pela não solução dos três problemas clássicos da matemática grega com o uso apenas dos instrumentos euclidianos, isto é, identificar as novas estratégias de resolução dos referidos problemas que possibilitaram diferentes ramos de estudos na matemática. Como visto, abrir mão da restrição a régua não graduada e compasso foi uma verdadeira expansão de soluções alternativas, motivando inventos matemáticos, como por exemplo, curvas especiais, que alimentou a criatividade de antigos matemáticos, abrindo espaço para o desenvolvimento das atividades heurísticas.

Toda a pesquisa realizada proporcionou um aprimoramento de meus conhecimentos, principalmente no que concerne a ciência heurística e sua importância na matemática, em especial nos três problemas clássicos da matemática grega. Além disso, ficou evidente o quanto os referidos problemas foram determinantes para o estudo e desenvolvimento da matemática, mostrando que muitas vezes a não solução de um problema matemático pode ser fundamental para o desenvolvimento de outras áreas desta ciência, pois favorece a heurística, que encaminha a novos paradigmas de estudos.

Pudemos observar que boa parte do conhecimento matemático que temos hoje advieram de uma junção de vários ramos de estudos propiciados pela busca de solução dos três problemas clássicos da matemática grega. Muitas dessas novas descobertas nos parecem simples e evidentes, se olharmos com a matemática de hoje, no entanto, ao encarar estes problemas com as limitações que existiam na época, já que há casos de soluções que foram feitas em tempos muito remotos, podemos observar o quanto eram geniais algumas das invenções, como é o caso das 
soluções de Arquitas e de Menecmo. Assim, podemos ver o quanto determinante estes problemas foram para a promoção de novas estratégias de solução de problemas matemáticos, como é o caso da redução de um problema a outro mais simples, como aquela feita por Hipócrates.

Esperamos que os conteúdos matemáticos trabalhados nesta pesquisa possam ser vistos de maneira mais abrangente, ou seja, que possam ser analisados além do algoritmo de resolução do problema em si, como também as novas descobertas que encaminharam a solução dos problemas e a heurística que proporcionou tais descobertas. Por isso, identificar o potencial heurístico em problemas matemáticos pode ser fundamental para entender o processo de criação, desenvolvimento e perspectivas na matemática.

Podemos dizer que o método da pesquisa é um trabalho complexo e desafiador, principalmente em matemática, mas as implicações científicas que aquele proporciona, em especial para o investigador,é bastante significativo. Pude observar isso durante toda a pesquisa, pois tive que resgatar e relacionar vários conhecimentos adquiridos durante todo o curso, para que pudesse vir a compreender as diversas soluções alternativas para os problemas clássicos, identificar a heurística por traz dessas soluções e promover algumas estratégias de ensino que envolvam estes problemas, pondo em destaque a heurística na dinamização e propulsão de novos conhecimentos.

Para compreender as soluções alternativas, foi importante reavivar o conhecimento em relação às operações algébricas, definições de polinômios, limite, derivada, integral, geometria analítica e diferencial, competências que julgo serem conteúdos básicos e cruciais para qualquer mestre em matemática. Também pudemos observar com maior clareza os princípios da geometria euclidiana, como por exemplo, técnicas de construções geométricas e a solução de diversos problemas por meio destas técnicas.

Em relação à ciência heurística, a pesquisa me proporcionou um vasto conhecimento, principalmente no que concerne à matemática. Pudemos observar que a atividade heurística na matemática já é algo estudado há algum tempo e que vários filósofos e matemáticos já expuseram a importância dessa ciência para o desenvolvimento da matemática. Observamos também algumas vertentes da heurística e sua notável capacidade de promover descobertas e novos caminhos que diferem totalmente do tradicional, gerando novos estudos, novas estratégias e potencializando o conhecimento científico.

Por fim, esperamos que esse trabalho contribua com o conhecimento dos 
4. Implicações educacionais dos três problemas clássicos da matemática grega para o ensino

interessados nesta área, sobre a correlação existente entre heurística e matemática, identificando o potencial das atividades heurísticas nos três problemas clássicos da matemática grega. Além disso, espero que outras possíveis reflexões acerca do assunto tratado sejam futuramente analisadas, visto que esta correlação ainda é pouco entendida e estudada na atualidade. Como visto brevemente no último capítulo, atrelar à resolução de problemas matemáticos à heurística pode ser uma eficiente ferramenta de ensino, capaz de promover um ensino/aprendizagem mais dinamizado. 


\section{REFERÊNCIAS BIBLIOGRÁFICAS}

[1] BACHELARD, Gaston. A formação do espírito científico: Contribuição para uma psicanálise do conhecimento. Tradução Estela dos Santos Abreu, $5^{\circ}$ reimpressão. Rio de Janeiro: Contraponto. 1996.

[2] BARBOSA, J. P.; NETO, F. R. de Assis Pierre Laurent Wantzel: O Ultimo Capitulo de Dois dos Três Problemas Clássicos. Anais do IX Seminário Nacional de História da Matemática. Sociedade Brasileira de História da Matemática, 2010 .

[3] BAZARIAN, Jacob. Intuição Heurística: uma análise heurística da intuição criadora. $3^{\circ}$ Ed. São Paulo: Editora Alfa - Omega, 1986.

[4] BOYER, Carl. História da Matemática. Editora Edgard Blücher, 1993.

[5] CARVAlHO, João Pitombeira. Os três problemas clássicos da matemática grega. Pontifica Universidade Católica do Rio de Janeiro - Rio de janeiro RJ, 2008.

[6] CAVACAMI, Eduardo.; FURUYA, Y. K. S. Explorando Geometria com Origami. São Paulo. 2010.

[7] CHAVES, Valteni Douglas. As Contribuições da História da Matemática na Compreensão dos Conceitos e das Aplicações da Derivada: Uma Abordagem Heurística. Universidade Estadual de Santa Cruz - UESC, 2011. 
[8] CUNHA, Haroldo Lisbôa da Sobre a quadratura do círculo. Revista Nacional de Educação. Rio de Janeiro: Museu Nacional, v. 18-19/20, 1934.

[9] D‘ACAMPORA, Raphael. Solução dos três problemas classicos da matematica grega por curvas mecânicas. Dissertação de mestrado profissional em matemática, Universidade Federal de Santa Maria. Santa Maria - Rio Grande do Sul, 2014.

[10] EUCLIDES. Elementos de Euclides: dos seis primeiros livros, do undécimo, e duodécimo. Versão latina de federico commandino. Traduzidos em português do real colégio de nobres. Biblioteca nacional, 1976.

[11] EVES, H. Introdução à História da Matemática. Tradução Hygino Domíngues. Campinas: Editora da Unicamp, 2004.

[12] FERREIRA, Eduardo Sebastiani. Nicomede e os três problemas clássicos gregos. Revista Brasileira de História da Matemática - Vol. 10 n 20. Publicação Oficial da Sociedade Brasileira de História da Matemática. IMECC-UNICAMP - Brasil, 2011.

[13] FILHO, Inocêncio Fernandes Balieiro. Arquimedes, Pappus, Descartes e Polya - Quatro Episódios da História da Heurística. Tese de Doutorado, Universidade Estadual Paulista- Instituto de Geociências e Ciências Exatas. Rio Claro-SP, 2004.

[14] FREITAS, Juliana Martins. Os três problemas clássicos da matemática grega. Universidade Estadual Paulista "Julio de Mesquita Filho". Dissertação de mestrado. São José do Rio Preto, 2014.

[15] GOnÇALVES, Carlos H. B. Os Três Problemas Gregos e Construções com Régua e Compasso. V Seminário Nacional de História da Matemática Rio Claro. 2003.

[16] GARBI, Gilberto. A Rainha das Ciências: Um passeio histórico pelo maravilhoso mundo da Matemática. $3^{\circ}$ ed. São Paulo: Livraria da Física, 2009. $462 \mathrm{p}$.

[17] GARCIA, Afrânio da Silva. Retórica: a função heurística da linguagem. I Simpósio de Estudos Filológicos e Linguísticos. CiFEFiL, FFP(UERJ). Rio de Janeiro, 2008. 
[18] HEATH, T. A history of Greek mathematics. Two volumes. New York: Dover, 1981.

[19] JÚNIOR, Luís Pereira da Silva. Construções geométricas por régua e compasso e números construtiveis. Dissertação de mestrado profissional em matemática, Universidade Federal de Campina Grande. Campina Grande - Paraiba, 2013.

[20] KNORR, Wilbur Richard. The Ancient Tradition of Geometric Problems. Dover, New York, 1993.

[21] LAKATOS, Imre. A lógica do descobrimento matemático: provas e refutações. Tradução de Nathanael C. Caixeiro, Rio de janeiro, Zahar Editores, 1978.

[22] LAKATOS, Imre. La metodología de los programas de investigación científica. Alianza Universidad. Editado por John Worall y Gregory Currie. Versión española de Juan Carlos Zapatero. Madrid, 1983.

[23] LEITE, Paulo Ferreira. Motivação, Heurística e Rigor no Ensino da Matemática. Instituto de Matemática e Estatística - IME/USP. São Paulo, 2010.

[24] MOL, Rogério Santos. Introdução à história da matemática. Universidade federal de Minas Gerais. Belo Horizonte: CAED-UFMG, 2013.

[25] MONTEIRO, Liliana Cristina Nogueira. Origami: História de uma Geometria Axiomática. Universidade de Lisboa. Mestrado em Matemática para o Ensino, 2008.

[26] OLIVEIRA, Angelina Carrijo de.; NOGUEIRA, Antônio Carlos. Os Três Problemas Clássicos da Matemática Grega. XXXIII congresso nacional de matemática aplicada e computacional. Publicação da SBMAC, 2010.

[27] PIRES, Inara Martins.; ALVAREZ, Tana Giannasi. Uma nova didática para o ensino de matemática: o método heurístico e a reforma Francisco Campos. Pontifica Universidade Católica de São Paulo, Educação Matemática. São Paulo, 2003.

[28] PLURES. Humanidades Revista do Programa de Pós-Graduação em Educação. Centro Universitário Moura Lacerda. Mestrado, ano 10, n 11. Ribeirão Preto, jan. - jun. 2009. 
[29] POLYA, George. A arte de resolver problemas: um novo aspecto do método matemático. Tradução e adaptação de Heitor Lisboa de Araújo. Universidade Federal do Rio de Janeiro. Editora interciência. Rio de Janeiro, 1994.

[30] PUCKIN,V. N. Heurística: a ciência do pensamento criador. Rio de Janeiro, Zahar editores, 1969.

[31] ROQUE, Tatiana. História da matemática: uma visão crítica, desfazendo mitos e lendas. Editora Zahar. $2^{\circ}$ reimpressão, Rio de Janeiro - 2012.

[32] SANTANA, Luciano Melo. Os problemas clássicos da geometria e a impossibilidade de solução com régua e compasso. Dissertação de mestrado profissional em matemática, Universidade Federal do Estado do Rio de Janeiro. Rio de Janeiro - RJ, 2013.

[33] STERNBERG, Robert J. Inteligência para o Sucesso Pessoal. Rio de Janeiro: Campus, 2000.

[34] SOUSA, José Miguel Rodrigues. Trissecção do Angulo e Duplicação do Cubo: as Soluções na Antiga Grécia. Tese de mestrado em matemática, Faculdade de Ciências da Universidade do Porto. Porto - Portugal, 2001.

[35] SZABÓ, A. The Beginnings of Greek Mathematics. Reidel. Dordrecht, 1978.

[36] TEIXEIRA, Francisco Gomes. Traité des courbes spéciales planes et gauches. volume III. Paris: Jacques Gabay, 1995. 1ª ed. Coimbra: Universidade de Coimbra, 1909.

[37] TORRANCE, Ellis Paul. Criatividade: medidas, testes e avaliações. São Paulo: IBRASA, 1976.

[38] TREVISAN, Eberson Paulo. Contribuições da lógica do desenvolvimento matemático de Imre Lakatos ao trabalho com provas e demonstrações no ensino de matemática. Revista educação, cultura e sociedade. Sinop/MT, v.3, n.1, p.136-148, jan./jun. 2013.

[39] VASCONCELOS, Fernando. História das Matemáticas na Antiguidade. Aillaud e Bertrand. Lisboa, 1925.

[40] van der WAERDEN, B. L. Geometry and Algebra in Anciente Civilization. Springer-Verlag, New York, 1983. 
[41] ver EECKE, P. Pappus de Alexandrie: La Collection Mathématique. Albert Blanchard, Paris, 1982.

[42] ver EECKE, P. Les Oeuvres Complètes d'Archimède. Albert Blanchard, Paris, 1960.

[43] YATES, Robert C.The trisection problem. Reston, Virginia: The National Council of Teachers of Mathematics, 1971. Classics in mathematics education, $\operatorname{vol} 4$. 